\title{
9. MIOCENE TO PLEISTOCENE BENTHIC FORAMINIFERS AND PALEOCEANOGRAPHY OF THE MIDDLE AMERICA SLOPE, DEEP SEA DRILLING PROJECT LEG 84
}

\author{
Kristin McDougall, U.S. Geological Survey, Menlo Park, California ${ }^{2}$
}

\begin{abstract}
Miocene through Pleistocene benthic foraminifers from Sites 566-570 on the landward slope of the Middle America Trench were examined to determine depositional history, depositional depths, water-mass changes, and downslope transport. This study indicates that these sites have undergone a gradual uplift since at least Miocene time. Deposition has occurred at middle bathyal to abyssal depths, and under the influence of early Miocene bottom water, early Miocene intermediate water, deep central Pacific bottom water, Antarctic Bottom Water, Pacific Deep Water, and Pacific Intermediate Water. Missing or dissolved intervals in the section correlate with expansions of corrosive bottom waters and widespread deep-sea hiatuses.

Lower Miocene assemblages indicate that both a deep central Pacific bottom water and an early Miocene bottom water existed on the lower slope. Pacific bottom-water assemblages indicate that a deep-water corridor connected the Pacific and Caribbean at this time. In the late early to middle Miocene, the early Miocene bottom water appears to have been restricted to even greater depths, as indicated by improved preservation of the calcium carbonate tests. The appearance of the benthic foraminifers indicative of low-oxygen conditions suggests the development of a low-oxygen intermediate water mass by late early to middle Miocene. Also, uplift in Central America appears to have affected the deep and intermediate water-mass connections between the Caribbean and Pacific, as suggested by increased transport of shallow-water assemblages, decreased water depth, and associated changes in the water masses.

Upper Miocene through Pliocene sections are incomplete, but faunal assemblages indicate the presence of the Pacific Intermediate Water and Antarctic Bottom Water. Water depths did not change during the late Miocene, and may have been slightly deeper during the Pliocene. Poor preservation of faunas, resulting from high-latitude cooling and associated expansion of the Antarctic Bottom Water, obscures trends of depositional depth. Subaerial emergence of Panama land bridge appears to have occurred at this time. Water depth generally decreased in the Pleistocene, and the water masses achieved their modern distributions.
\end{abstract}

\section{INTRODUCTION}

On DSDP Leg 84, drilling was conducted at a series of sites on the landward slope of the Middle America Trench off Guatemala and Costa Rica. The sites were selected to test the accretionary model proposed by Seeley et al. (1974). The Guatemalan transect comprises five sites drilled at water depths ranging from $1718 \mathrm{~m}$ (Sites 570 ) to $5529 \mathrm{~m}$ (Site 567) (Fig. 1). The Costa Rican site (565), farther south, will not be considered in this study. Although these sites are presently located on the landward side of the trench, they may not have been in the past. One of the goals of Leg 84 was to interpret the tectonic history of this margin. Benthic foraminifers, which are particularily sensitive to physicochemical properties of seawater, provide a means of reconstructing the paleoceanography, and ultimately aid in interpreting the tectonic history.

Shelf and upper-slope benthic foraminiferal faunas have been widely studied, and are the basis for most benthic foraminiferal chronologies and paleoecologic interpretations, whereas deep-sea benthic foraminiferal faunas have only recently received attention. Ecologic and paleoecologic studies of the shelf and upper-slope faunas have suggested correlations between the distribution

\footnotetext{
${ }^{1}$ von Huene, R., Aubouin, J., et al., Init. Repts. DSDP, 84: Washington (U.S. Govt. Printing Office).

2 Address: U.S. Geological Survey, Branch of Paleontology and Stratigraphy, M/S 915 , 345 Middlefield Road, Menlo Park, CA 94025.
}

of a species or a morphology and various physicochemical properties (e.g., see Ingle, 1980; Douglas, 1979, 1981). This correlation is frequently expressed as the upper depth limit of a species or as a biofacies fauna. Studies of the deep-sea faunas indicate that there is a correlation between the distributions of water masses and benthic foraminifers, and that these distributions can be traced through time (see, e.g., Woodruff and Douglas, 1981; Woodruff, in press). Techniques and conclusions from these studies can be used to reconstruct paleoceanographic conditions of a particular area.

Sites on the Middle America Trench and slope have undergone a series of depth changes because of tectonic activity. Water masses influencing the benthic foraminifers varied through time, as a result of the climatic changes and tectonics. Benthic foraminifers contained in the sediments at these sites are a mixture of the shelf, slope, and abyssal faunas, so paleoecologic interpretations can be based on a variety of techniques. The purpose of this study is to interpret the depth of deposition, water-mass character, and downslope transport as indicated by the benthic foraminifers, and from these interpretations to reconstruct the paleoceanography of the Middle America slope.

\section{PROCEDURE}

The paleoecologic interpretations are achieved largely through analysis of the biofacies represented in each sample. A biofacies defined by water depth is recognized by a species whose upper depth limit falls within the biofacies depth range. Biofacies and associated faunas for the Middle America margin were determined from Holocene studies 


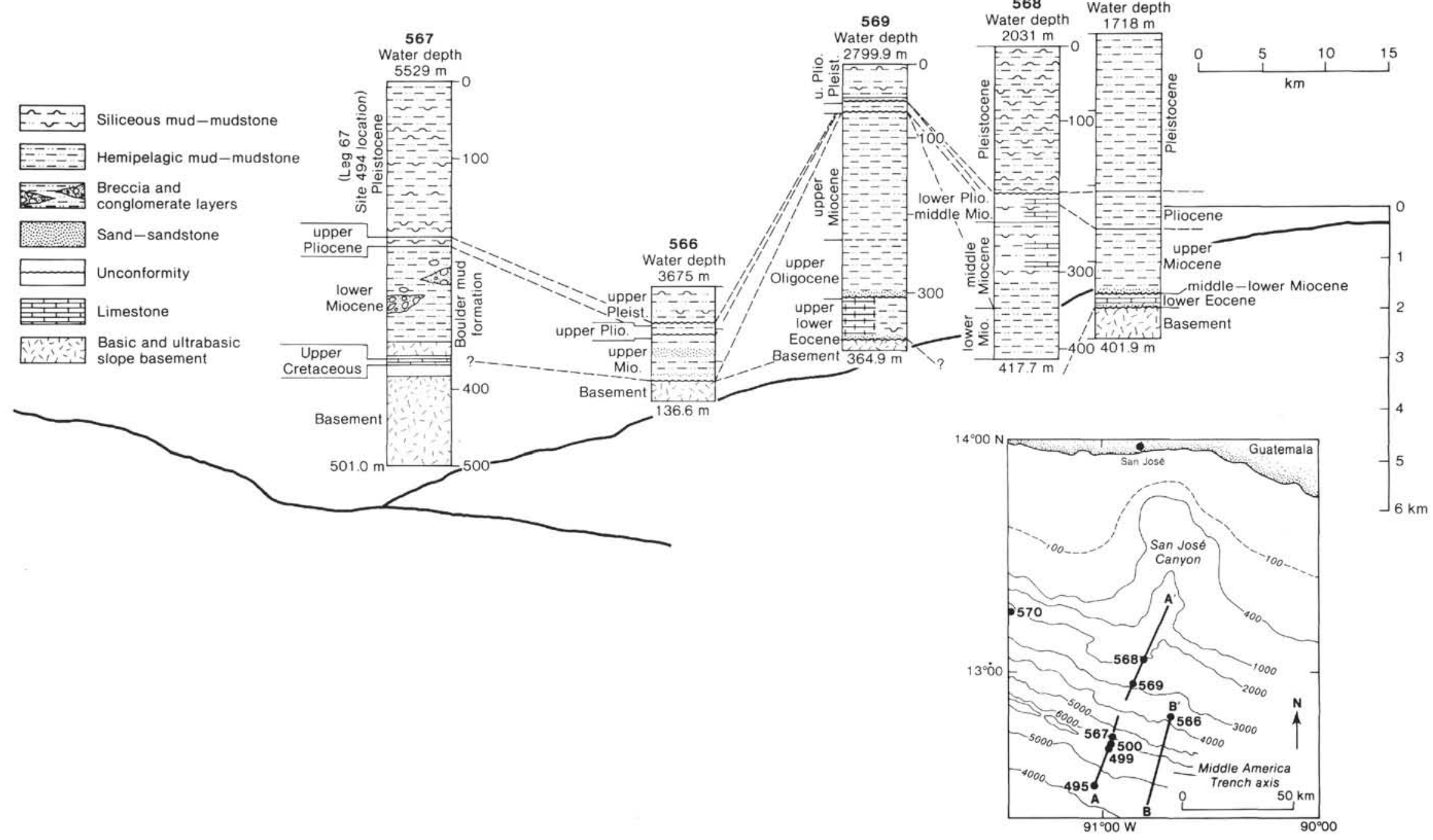

Figure 1. Locations and bathymetric distribution of the Leg 84 Guatemalan sites. Numbers at right of each column give sub-bottom depth (m). Bathymetric contours on inset in meters. 
in the equatorial Pacific (Wyrtki, 1966; van Andel et al., 1975; Smith, 1964; Golik and Phleger, 1977; Bandy and Arnal, 1957; Thompson, 1982 ) and from more general studies along the East Pacific Margin (Uchio, 1960; Ingle, 1980; Ingle and Keller, 1980; Resig, 1981) and in the Caribbean (Phleger, 1960; Bandy, 1956; Pflum and Frerichs, 1976). Upper depth limits of benthic foraminifers used in this study are given in the Taxonomic Notes (Appendix).

The biofacies analysis examines the abundance of species indicative of the various biofacies in an assemblage; the deepest biofacies represented indicates the minimum depth of deposition. In a stratigraphic section, changes in water depth, transported or mixed faunas, and selective preservation or dissolution appear as deviations in the biofacies pattern (Douglas, 1979, 1981; Ingle, 1980; Baltuck et al., this volume). The size, shape, and condition of the foraminiferal tests and/or the presence of age-diagnostic or water-mass-specific species in the assemblage help determine the cause of the change in biofacies pattern.

The presence of key species or assemblages is used to identify specific water masses and associated physical-chemical conditions. These interpretations rely heavily on the work of Woodruff (1979 and in press). Additional information on benthic foraminifers and water-mass associations is taken from Burke (1981), Lohmann (1978), Streeter (1972, 1973), Smith (1964), and Ingle and Keller (1980). Water masses presently impinging on the Middle America margin include the Surface Water, Pacific Intermediate Water (PIW), Pacific Deep Water (PDW), and Antarctic Bottom Water (AABW) (Wyrtki, 1966; van Andel et al., 1975). Because the early Miocene ocean was warmer, less stratified, and less oxygenated than the middle to late Miocene or modern ocean, Woodruff (in press) recognizes faunal assemblages associated with early Miocene bottom water, intermediate water, and deep central Pacific bottom-water masses. Early Miocene bottom-water assemblages were found below $3.2 \mathrm{~km}$ water depth, and included species which became extinct $14 \mathrm{Ma}$ ago, moved to shallower depths (less than $2.5 \mathrm{~km}$ ) after $14 \mathrm{Ma}$ ago, or are presently associated with the AABW. The early Miocene intermediate-water assemblages were found above $2.6 \mathrm{~km}$ water depth, and included species which are extinct or are now associated with the PIW and low-oxygen conditions. The deep central Pacific bottom-water assemblages were found in deep bottom-water corridors, and are believed to represent the influx of new dense bottom waters during glacial expansions. Since similar benthic foraminiferal assemblages were found on the Middle America slope, these early Miocene water masses will be included in the analysis. Water mass and other physicochemical associations or constraints of the benthic foraminiferal species used in this study are given in the Taxonomic Notes (Appendix). The locations of the DSDP sites and the distribution of water masses with respect to the benthic foraminiferal biofacies for the Middle America margin are summarized in Figure 2.

Because pre-Miocene sediments are strongly dissolved, discontinuous, or nonfossiliferous, and because the knowledge of paleoceano- graphic associations of the older species is less reliable, the present study concentrates on the Miocene to Recent sediments. In the Guatemalan transect this includes the sediments in Cores 570-1 to 570-35, $568-1$ to $568-44,569-1$ to $569-27,569 \mathrm{~A}-\mathrm{H} 1$ to $569 \mathrm{~A}-6,567-\mathrm{H} 1$ to $567-2$, and $567 \mathrm{~A}-\mathrm{H} 1$ to $567 \mathrm{~A}-13$. These samples were prepared according to methods described by Stone and Keller (this volume); benthic foraminiferal faunal lists are given in Tables 1-6 (Table 2 is in back pocket); Table 7 identifies the barren samples. Since age interpretations based on benthic foraminifers are not emphasized in this chapter, ages based on planktonic foraminifers (Stone and Keller, this volume) and calcareous nannofossils (Filewicz, this volume) are used. Benthic foraminifers clarify these interpretations in intervals where they are the only preserved microfossils (Fig. 3). Also, where possible, the barren or dissolved intervals are correlated with the sequence of latest Oligocene (PH) and Miocene (NH1-NH7) deep-sea hiatuses described by Keller and Barron (1983). Biofacies and water-mass interpretations are discussed first for each site in this transect. These interpretations are then summarized, and provide the basis for reconstructing the Miocene to Pleistocene oceanography for the Middle America margin.

\section{SITE 570}

Site 570 is $40 \mathrm{~km}$ landward of the trench axis on the upper part of the slope, in the area presently considered the lower middle bathyal biofacies and where the PIW impinges on the slope (Fig. 2). Sediment recovered at this site ranges from Eocene to Pleistocene. Planktonic foraminifers indicate that at a major unconformity occurs between Cores 570-35 and 570-36; cores below this unconformity are no younger than early Eocene, and cores above it range from Miocene to Pleistocene. Age interpretations based on planktonic foraminifers for the upper cores are early Miocene (570-35,CC and 570-35-4), late Miocene (570-35-1 to 570-35-28), Pliocene (570-28-3 to 570-24-1), Pliocene-Pleistocene undifferentiated (570-23 to 570-23-22), and Pleistocene (570-20 to 570-1) (Filewicz, this volume; Stone and Keller, this volume). Benthic foraminifers are generally consistent with the age interpretations based on planktonic foraminifers (Fig. 3).

Biofacies analysis of Site 570 indicates a fairly uniform pattern throughout most of the section, with deposition having occurred in the lower bathyal biofacies (Fig. 4 [back pocket]; Table 1). Water masses influencing the faunas were deep central Pacific bottom water (570-35), ABW (570-34 to 570-33, 570-28, and 570-26 to

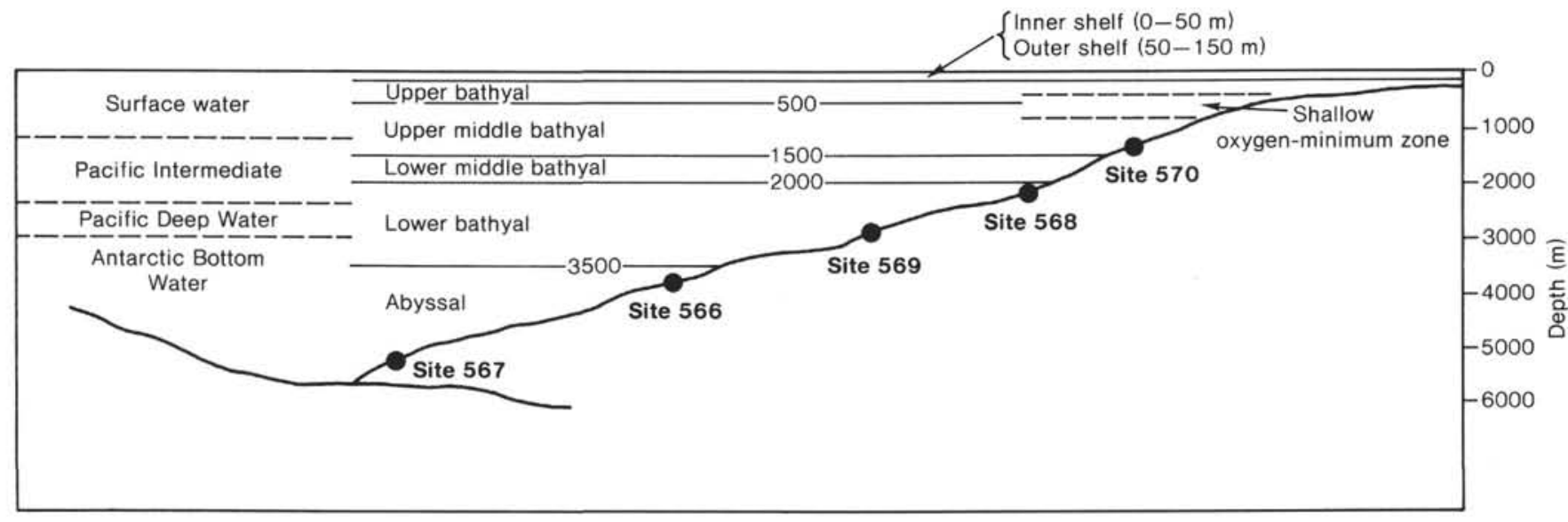

Figure 2. Distribution of water masses, benthic foraminiferal biofacies, and DSDP Leg 84 sites along the landward slope of the Middle America Trench. The water-mass distribution follows Smith (1964), Wyrtki (1966), and van Andel et al. (1975). Biofacies distribution is from Bandy and Arnal (1957), Golik and Phleger (1977), Smith (1964), Ingle (1980), Ingle and Keller (1980), and Thompson (1982). 


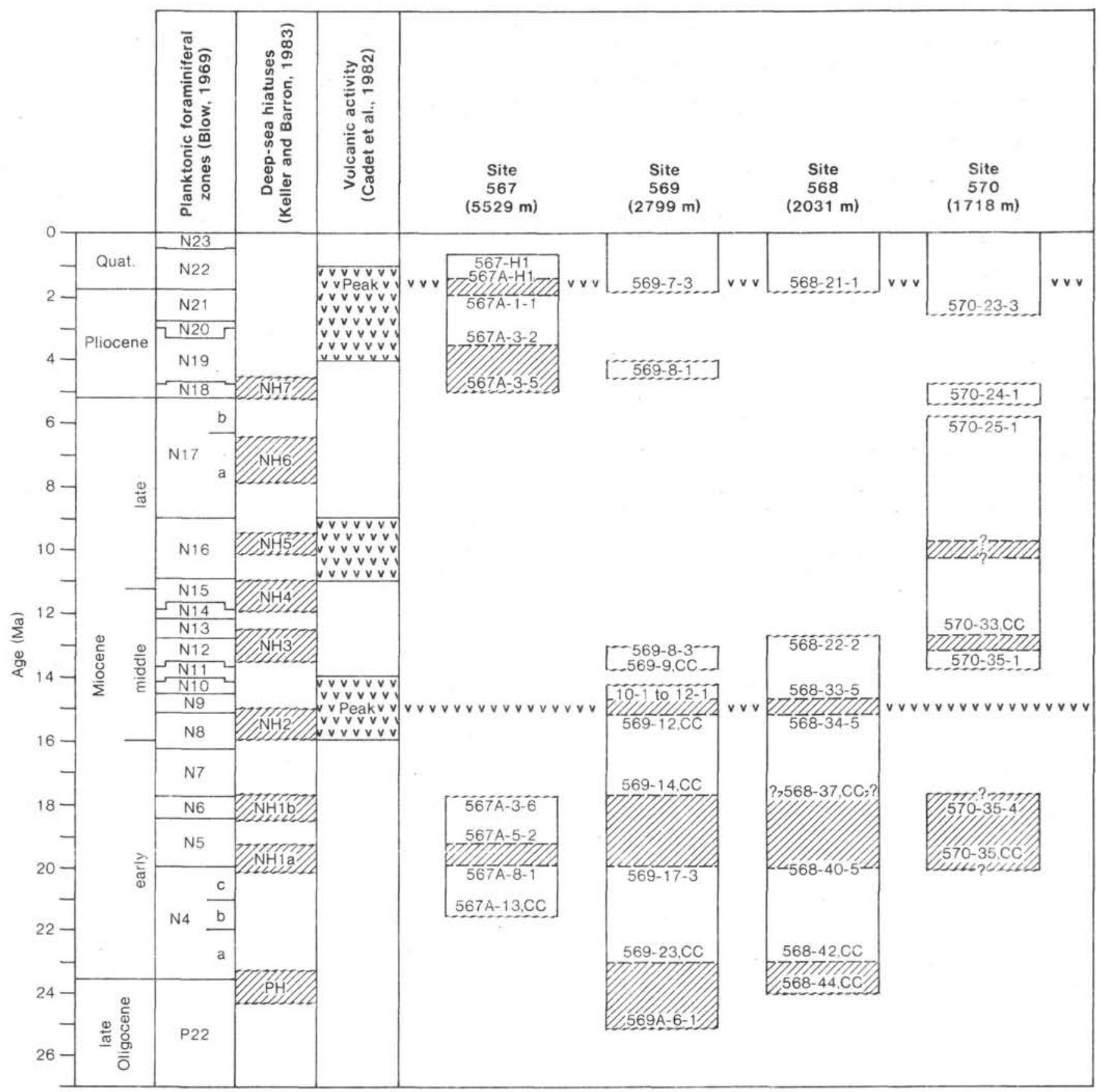

Figure 3. Age and correlation of DSDP Leg 84 sites, modified from Stone and Keller (this volume). Hachures indicate dissolved or barren intervals. Periods of peak volcanic activity are indicated by VVV.

570-24), PDW (570-23 to 570-18), and PIW (570-33 to $570-28,570-29$ to $570-23$, and $570-18$ to $570-1$ ) (Fig. 4 [back pocket]). The incursions of cold corrosive bottom waters in the Miocene of Site 570 correlate with deep-sea hiatuses recognized by Keller and Barron (1983). Planktonic foraminifers, calcareous nannofossils and benthic foraminifers, lower benthic foraminiferal diversities, and the presence of species commonly associated with deep central Pacific bottom water in Core 570-34 correlate with the early Miocene deep-sea hiatus NH1. In the stratigraphically higher Cores $570-33$ to $570-34$ and $570-28$, the age interpretations, as well as slightly lower foraminiferal diversities and the presence of species associated with the $\mathrm{AABW}$, indicate correlation with deep-sea hiatuses $\mathrm{NH} 3$ and $\mathrm{NH} 5$, respectively. Although species characteristic of the AABW continue to appear in Cores 570-26 through 570-24, the faunal turnover suggests that the dissolution in these cores and the presence of cold corrosive bottom waters are correlative with younger Miocene to Pliocene hiatuses such as NH6 or NH7. The youngest incursion of cold corrosive bottom water at Site 570 corresponds to the Pliocene to Pleistocene cold 
event 2.5 to $1.2 \mathrm{Ma}$ ago, evidence of which is recognized throughout the Pacific (Ingle, 1967, 1973; Kent et al., 1971; Bandy, 1972; Olsson, 1974; Schackleton and Opdyke, 1977; Keller, 1978; and Keller and Ingle, 1981) (Figs. 3 and 4 [ 4 in back pocket]).

Moderately well preserved early Miocene, middle bathyal species dominate the assemblages in Samples 570$35, \mathrm{CC}$ and $570-35-4,12-14 \mathrm{~cm}$, but the deepest faunas represented are from the lower bathyal and abyssal biofacies. Anomalinoides globosus and Stilostomella subspinosa are present. Woodruff (in press) associates these species with a deep central Pacific bottom-water mass that was present at depths of $2.5-3.0 \mathrm{~km}$ in the early Miocene (18-21 $\mathrm{Ma}$ ago), and which is interpreted as representing the influx of new dense cold bottom waters along deep ocean corridors. This interpretation corresponds to the lower bathyal abyssal depths, as indicated by the biofacies patterns. The abundance of uvigerinids, buliminids, stilostomellids, and siphonodosariids in these lower Miocene samples suggests the presence of loweroxygen conditions such as might be found in the PIW. The low abundance of the deep central Pacific bottomwater species, the absence of early Miocene bottom-water or AABW species, and the abundance of lower middle bathyal and PIW species suggest that either there was considerable downslope transport during the early Miocene at Site 570, or the early Miocene ocean was not well oxygenated and the occurrence of low-oxygen species was less restricted than at present.

Biofacies analysis of Sample 570-35-1, 20-22 cm indicates that depth and water-mass associations were similar to those in the early Miocene. Lower bathyal to abyssal biofacies species represent the deepest biofacies. Species associated with the PIW mass are common, but the presence of Epistominella umbonifera and Cibicidoides bradyi suggest that depths increased and/or the early Miocene bottom water or AABW expanded and migrated upslope. The latter interpretation is favored because in the overlying samples, 570-34,CC and 570-34-1, $121-125 \mathrm{~cm}$, foraminiferal assemblages show the effects of dissolution and a cold corrosive water mass, and the age of these assemblages corresponds to a period of climatic deterioration and cooling (Kennett et al., 1973; Shackleton and Kennett, 1975; Woodruff and Douglas, 1981; Keller and Barron, 1983; Stone and Keller, this volume). The presence of species associated with the AABW in Sample 570-35-1, 20-22 cm thus signals the coming climatic deterioration, an increase in AABW, and a corresponding rise in the calcium compensation depth (CCD), which subsequently caused the dissolution in Samples 570-34,CC and 570-34-1, 121-125 cm. It is possible for these changes to have occurred without a significant change in water depth.

Overlying the dissolution interval, benthic foraminiferal diversity and biofacies patterns are relatively uniform. Outer-shelf and upper-slope species dominate and represent the transported fauna, whereas the less abundant lower-slope and abyssal species represent the deepest biofacies fauna. Despite the apparent biofacies uniformity, the assemblages indicate subtle changes in the water mass.
In Samples 570-33, CC to 570-28-3, 48-52 cm, Osangularia culteri and species of Uvigerina, Stilostomella, and Siphonodosaria are common, and suggest the presence of the PIW. Species indicative of deeper water masses are absent, so deposition of Cores 570-33 through 570-28 probably occurred in the shallower part of the lower bathyal biofacies and under the influence of the PIW.

In Core 570-28, the diversity trend fluctuates noticeably, and although the biofacies distribution does not change, several species indicative of the AABW appear, such as Epistominella umbonifera, Cibicidoides bradyi, Laticarinina pauperata, and Pullenia quinqueloba. These forms continue as high in the section as Core 570-24. A faunal turnover occurs between Samples 570-28-1, 20-24 cm and 570-26-1, 14-16 cm as the modern shelf and slope species first appear. Thus, sediments in Core 570-28 through the lower part of Core 570-24 are interpreted as having been deposited in the lower middle bathyal biofacies under the influence of an expanded AABW.

Lower bathyal to abyssal faunas continue as the deepest biofacies represented in the Pleistocene faunas of Site 570 . Slight variations in the diversity pattern suggest cyclic changes such as would be encountered during glacial-interglacial cycles. Lower diversities in Cores $570-23$ to $570-19,570-15$ to $570-12$, and $570-4$ to $570-5$ could correspond to cold events which occurred in the Pacific region 1.2-2.5, 0.9, and 0.7 Ma ago (Ingle, 1967, 1973; Bandy, 1972; Olsson, 1974; Keller, 1978; and Keller and Ingle, 1981). Only the lowest of these intervals, Cores $570-23$ to $570-19$, contains rare species which have been associated with the cold AABW. The remainder of the Pleistocene section, including the lower-diversity intervals, indicates that the site has undergone a gradual uplift and/or that water masses have migrated downslope throughout the Pleistocene. Deposition continued to be within the lower bathyal biofacies up to the highest sample, 570-1,CC. The presence of the PIW is suggested by the abundance of the buliminids and uvigerinids and by the lack of species indicative of deeper water masses.

Transported faunas are present throughout the section recovered at Site 570. In the Miocene, shelf species comprise less than $20 \%$ of the faunas, whereas in the Pliocene and Pleistocene they average $20-40 \%$. Miocene shelf species are large, robust forms, usually with thicker tests, such as Quinqueloculina and Lenticulina. The abraded and worn condition of these tests supports the interpretation that these specimens were transported. Specimens from the Miocene upper bathyal biofacies have similar characteristics. In the Pliocene and Pleistocene, the transported shelf and upper-slope specimens are predominantly the plate-like bolivinids or the heavier conical forms such as Uvigerina or Bulimina. The change in the species transported is the result of evolution, water depth, and current patterns, as well as the proximity of the shelf and upper-slope regions. The composition and quantity of transported middle- and lower-slope species change little throughout the section. Sample spacing was too broad to identify transport mechanisms. 
Table 1. Faunal distribution, Site 570.

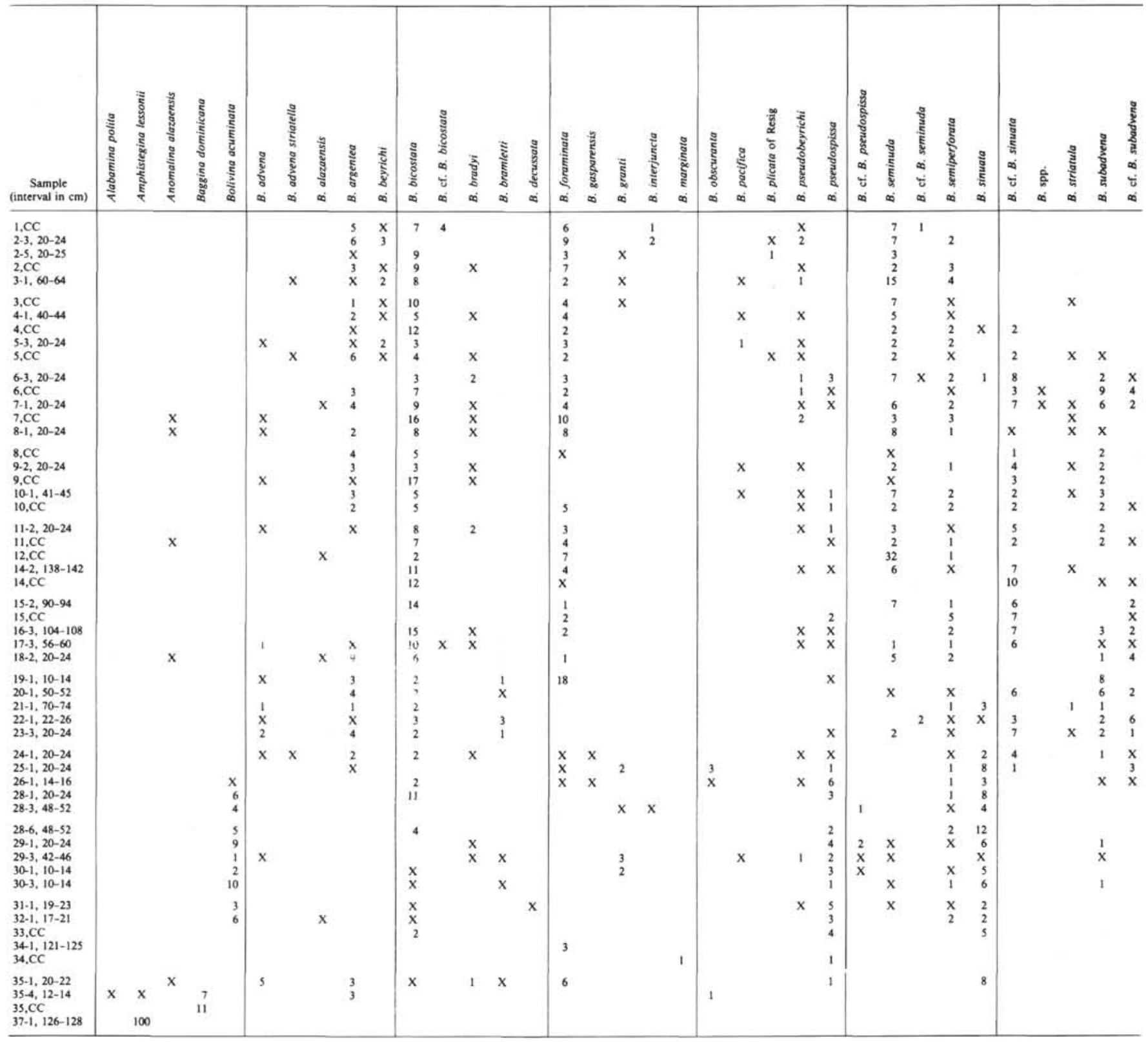

Note: Benthic foraminiferal occurrences are given as percent of total fauna. $X=$ less than $1 \%$. Biofacies abundances are also given in percent of total fauna.

\section{SITE 568}

Site 568, drilled in $2031 \mathrm{~m}$ of water, lies $47 \mathrm{~km}$ landward of the Middle America Trench axis (Fig. 1). This site is presently within the lower bathyal biofacies and under the influence of the PIW (Fig. 2). Age interpretations based on planktonic foraminifers indicate a nearly continuous lower to middle Miocene section (Cores 568-44 to 568-25), an undifferentiated Miocene to Pliocene dissolved interval (Cores 568-25 to 568-22), and a Pleistocene section (Cores 568-21 to 568-1) (Filewicz, this volume; Stone and Keller, this volume). Middle Miocene benthic foraminifers occur as high as Sample 568-23,CC, and therefore indicate that the dissolution from Core
568-25 to the lower part of Core 568-23 is correlative with deep-sea hiatus NH3. Dissolution in the upper part of Core 568-23 to Core 568-22 could be the result of a younger hiatus (Fig. 3).

Biofacies patterns at Site 568 are variable, and indicate a more complex paleoceanography than at Site $\mathbf{5 7 0}$. Deposition occurred in the lower bathyal to abyssal biofacies (Cores 568-42 to 568-34 and 568-27 to 568-22), lower bathyal biofacies (Cores 568-33 and 568-22 to 5681 ), and lower middle bathyal biofacies (Cores 568-38 to $568-34$ and $568-32$ to $568-27$ ) (Fig. 5 [back pocket]; Table 2 [back pocket]). Transport and dissolution is too extensive in Cores 568-44, 568-43, and 568-34 to provide a reliable biofacies interpretation. Water masses which 
Table 1. (Continued).

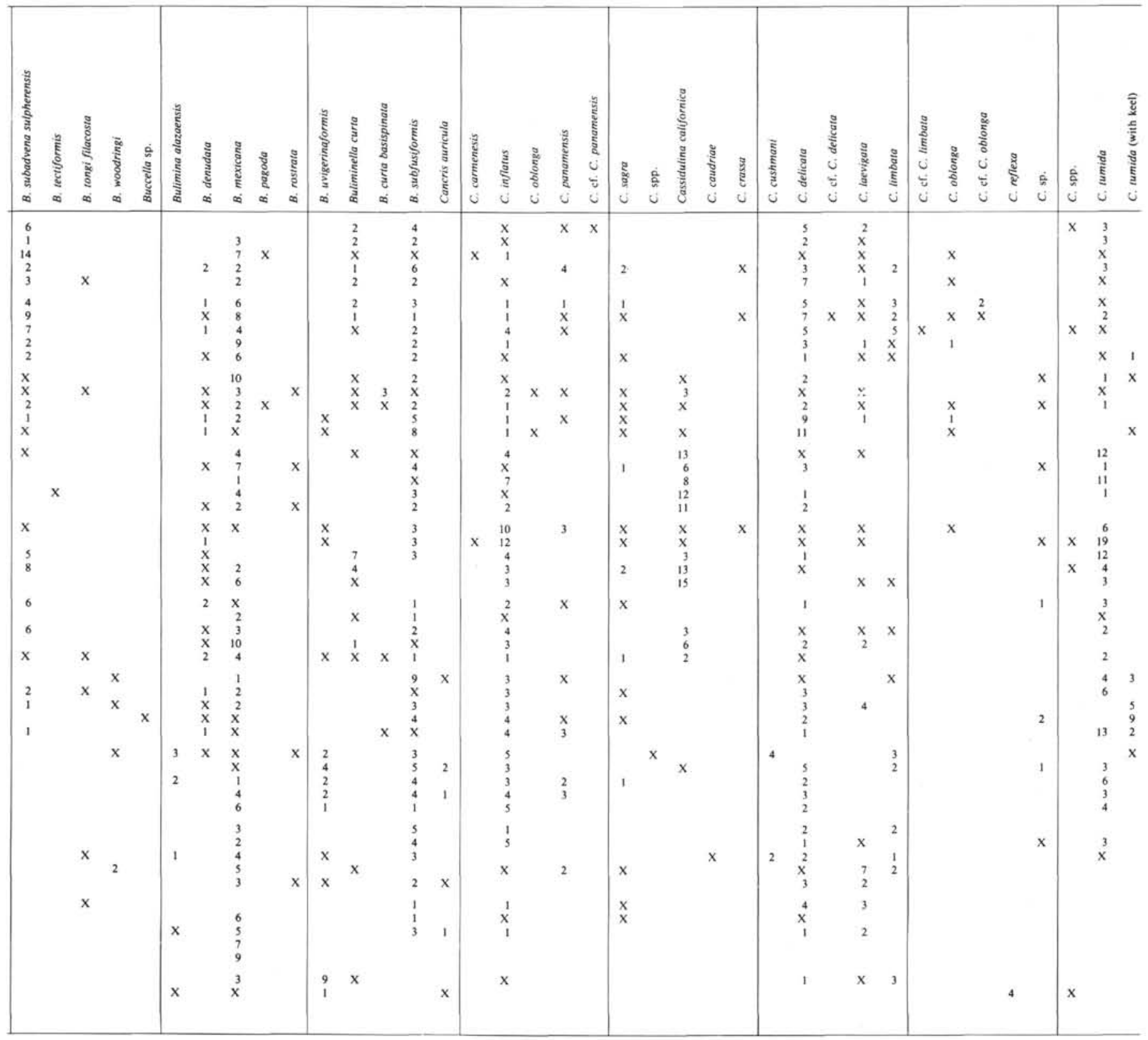

have affected the faunas at Site 568 include the early Miocene bottom water, the AABW, and PIW (Fig. 5 [back pocket]).

Benthic foraminiferal faunas in Cores 568-42 to 568-44 are dissolved and have low diversities and foraminiferal numbers, and the biofacies patterns are hard to interpret. Species from the probable in situ fauna are solution-resistant species of Gyroidina and Uvigerina hispi$d a$, which are characteristic of the lower bathyal biofacies and the early Miocene bottom water mass (Corliss and Honjo, 1981; Woodruff, in press). The dominant species in these assemblages are Nodosaria longiscata and other cylindrical forms which have broad ranges of water depth. Their presence here is probably the result of transport or winnowing.
The next group of samples, $568-42-5,91-95 \mathrm{~cm}$ to $568-38-3,82-84 \mathrm{~cm}$, contains benthic foraminiferal assemblages with high but variable diversities. The variability may be the result of downslope transport (higher diversities) and corrosive bottom waters (lower diversities) associated with the deep-sea hiatus NH1 (Keller and Barron, 1983). A major cooling, intensified deep currents, and increased corrosive bottom waters $18-20 \mathrm{Ma}$ ago (planktonic foraminiferal Zones N5 and N6) apparently caused deep-sea hiatus NH1 (Vail and Hardenbol, 1979; Bukry, 1982; Keller and Barron, 1983). This hiatus is most frequently recognized in sediments south of the area considered here (Keller and Barron, 1983), but the decreasing water depths which become evident in Core 568-40 and upsection, and the lower diversities in 
Table 1. (Continued).

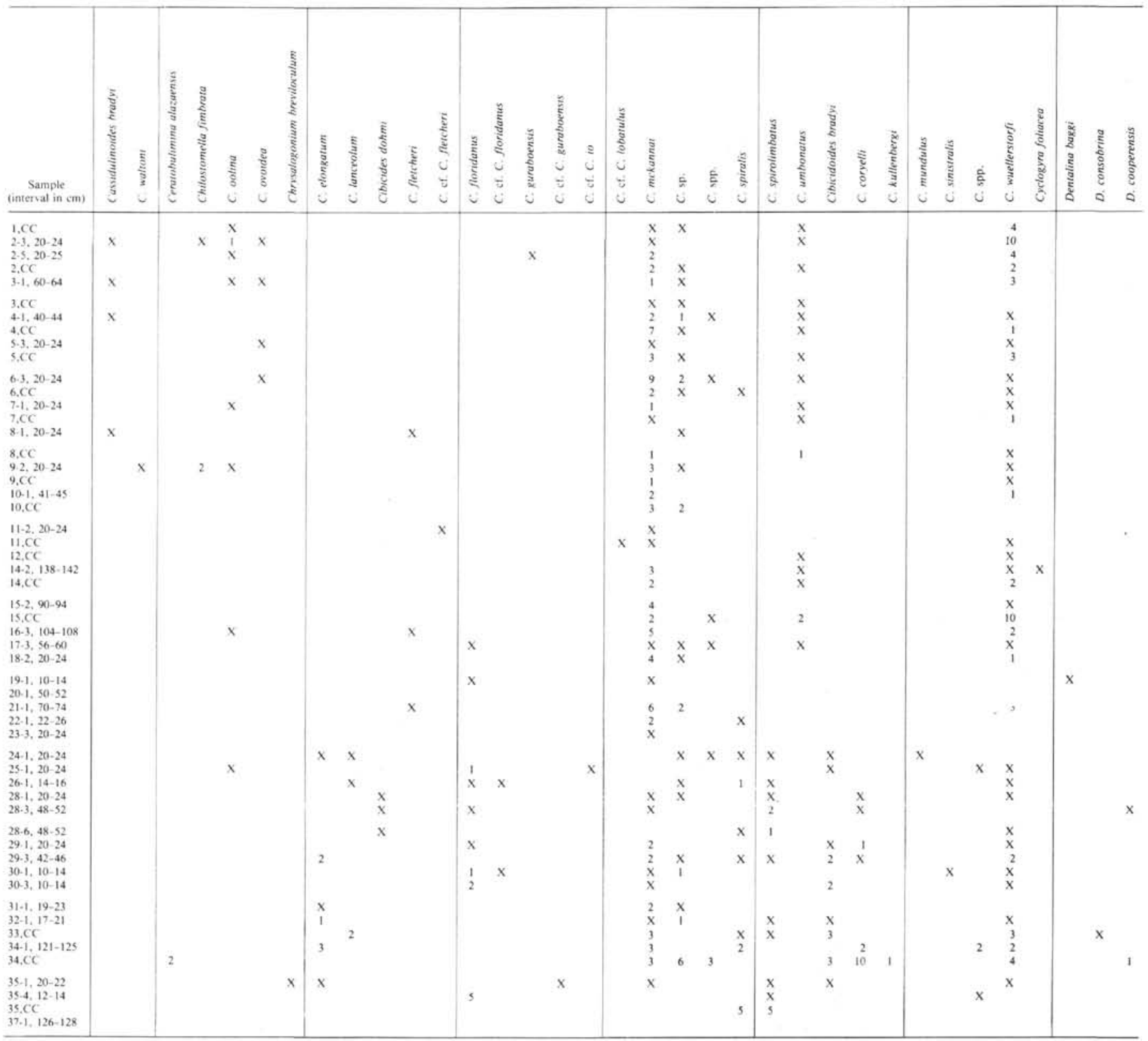

Core 568-40 and upper part of Core 568-38, may correspond to deep-sea hiatus NH1. The in situ fauna throughout Cores $568-42$ to $568-38$ is from the lower bathyal to abyssal biofacies, and contains rare to few specimens of Sigmoilina tenuis, Gyroidina soldanii, and G. planulata. These species decrease in abundance upsection, and are associated with the early Miocene bottom water (Woodruff, in press). Stilostomella, Chrysalongium, and Siphonodosaria are common in this interval, in part because of their elongate cylindrical shape, which transports easily, and also in part because these species are associated with the early Miocene bottom water. Thus, Sections 568-42-5 to 568-38-3 are interpreted as having been deposited in the lower bathyal biofacies under the influence of the early Miocene bottom water.
Although the diversity trend in Samples 568-38-1, $80-85 \mathrm{~cm}$ to $568-33-5,35-39 \mathrm{~cm}$ remains similar to that of the underlying samples, the biofacies pattern shifts so that the lower bathyal to abyssal species are rare and lower middle bathyal species dominate. There is also a corresponding change in water-mass-specific species. $\mathrm{Bu}$ limina alazaensis (B. rostrata of Woodruff, in press), $C i$ bicidoides bradyi, $C$. wuellerstorfi, Siphogenerina multicostata (Uvigerina multicostata of Woodruff, in press), and Osangularia culteri are common, and suggest the presence of an early Miocene, low-oxygen intermediate water mass (Woodruff, in press). Species of Stilostomella and Siphonodosaria also appear because of their association with both the early Miocene intermediate bottom water masses. The benthic foraminiferal assemblage 
Table 1. (Continued).

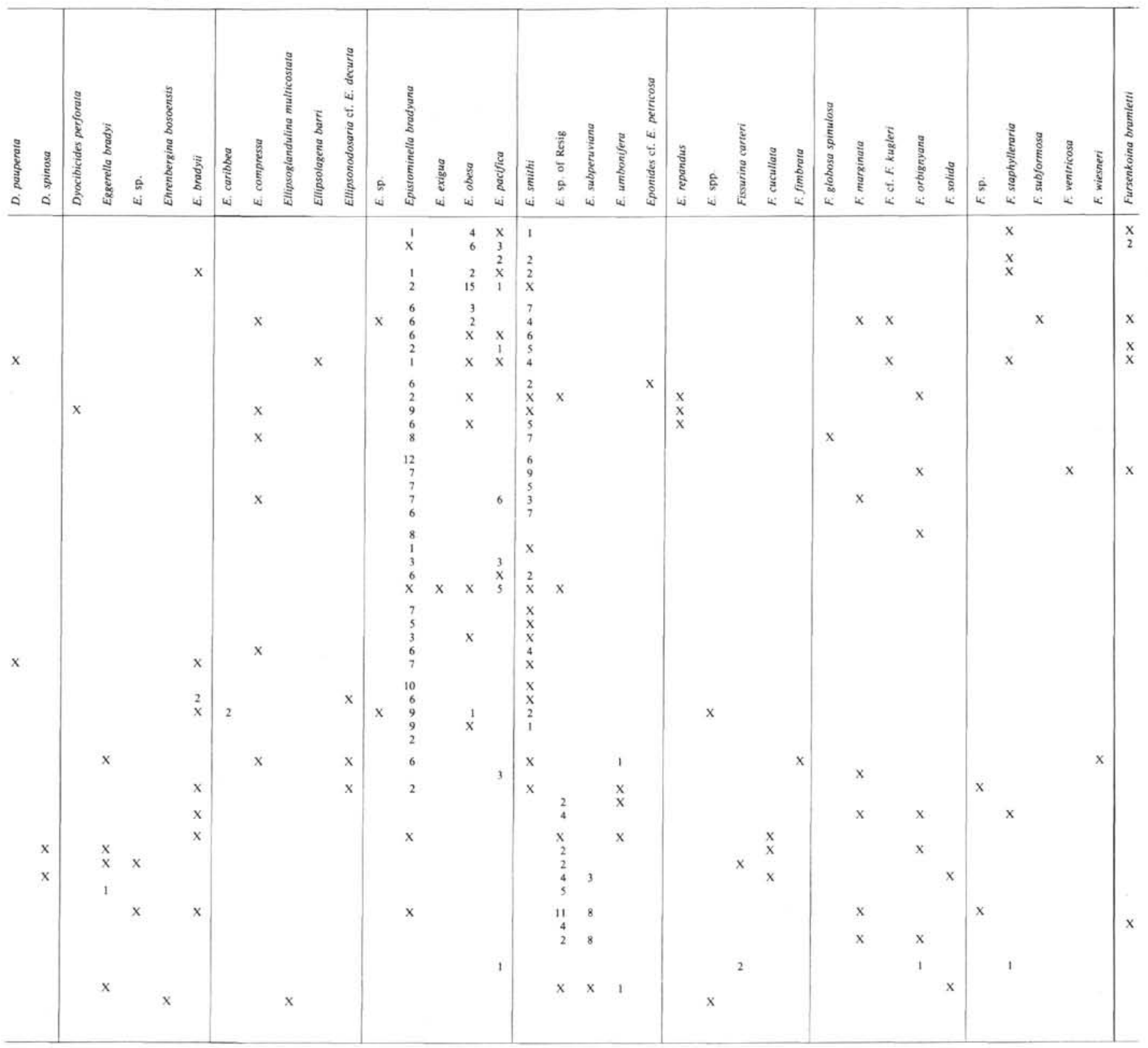

in Sample 568-38-1, 80-85 $\mathrm{cm}$ is transitional between the underlying and overlying sequences, so the change between the two assemblages is gradational. This interval is interpreted as having been deposited near the boundary between the lower middle bathyal and lower bathyal biofacies and near the boundary between the early Miocene intermediate and bottom water masses.

The rapid changes in the biofacies pattern in the upper part of Core 568-34 and the lower part of Core 568-33 are believed to result entirely from downslope transport. Nodosaria longiscata and other cylindrical forms are common to abundant in these assemblages. Although these species have broad water-depth ranges, the concentration of a particular shape and size suggests transport or winnowing of sediments. Additional transport- ed species are from the upper middle bathyal biofacies. The in situ fauna is believed to have been dissolved by corrosive bottom waters (AABW). This interpretation is based on the age determined from planktonic foraminifers and on the ecology of the adjacent samples. The age according to planktonic foraminifers equates this interval with the time of deep-sea hiatus $\mathrm{NH} 2$, and with intensification of the bottom currents (Stone and Keller, this volume; Keller and Barron, 1983). Biofacies patterns in the upper part of Core 568-33 show a dominance of lower bathyal species, particularly the solution-resistant forms associated with the AABW, such as Gyroidina soldanii, G. planulata, Sigmoilina tenuis, and Uvigerina hispida. Thus, sediments in the upper part of Core 568-34 and in Core 568-33 are interpreted as hav- 


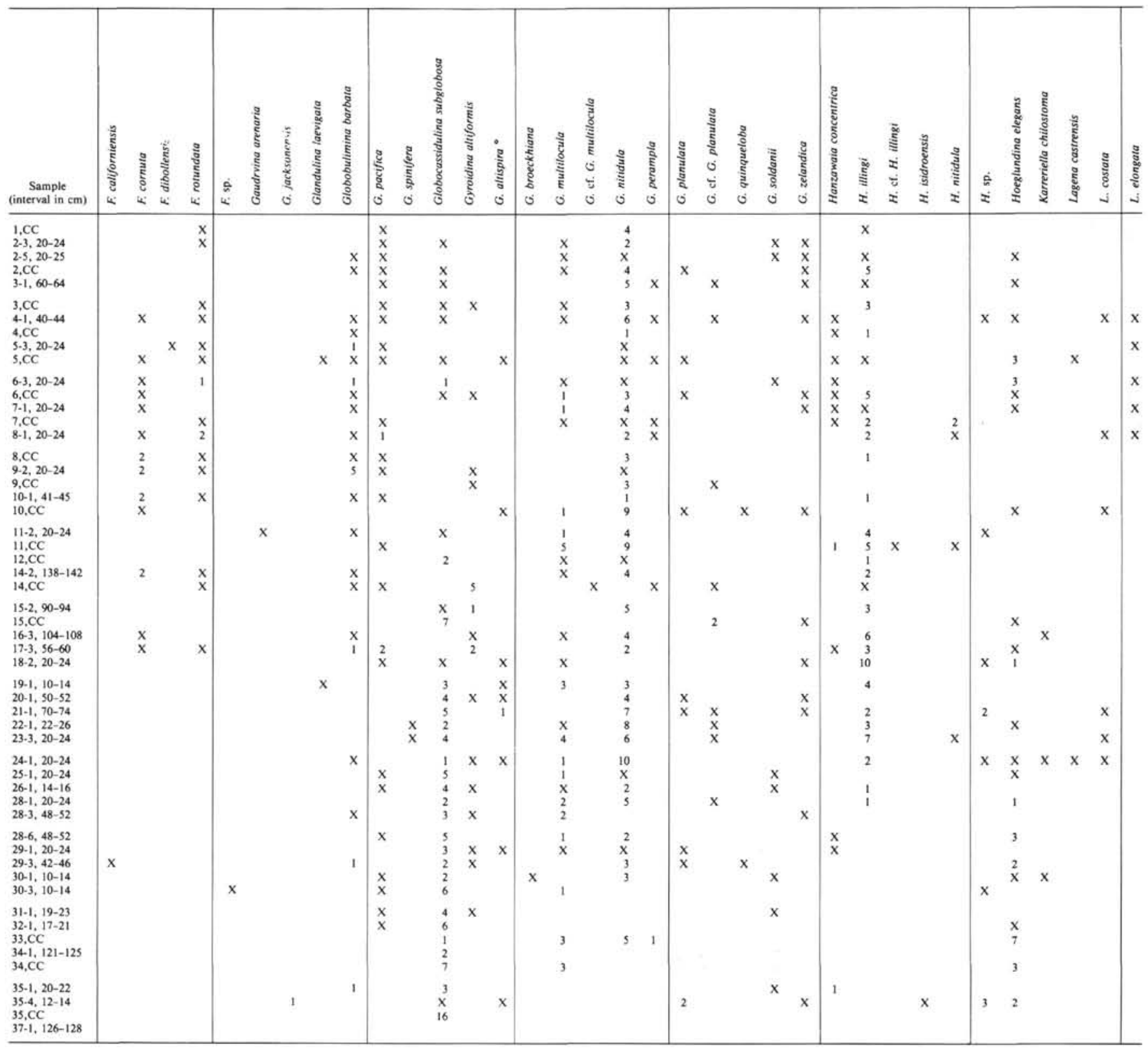

ing been deposited in the lower bathyal biofacies under the influence of corrosive bottom water and with considerable amounts of downslope transport.

Biofacies patterns in Cores 568-32 to 568-26 indicate that deposition occurred in the lower middle bathyal biofacies, with moderate transport from the shelf and upper slope. Species characteristic of PIW are common, and include Bulimina alazaensis, Osangularia culteri, and Siphogenerina multicostata. Also in this interval, there is a gradual turnover in the fauna, that is, there are numerous first and last occurrences between Cores 568-33 and 568-25.

Dissolution characterizes many of the foraminiferal faunas in Cores 568-22 to 568-25. The lower part of this interval correlates with the deep-sea hiatus NH3 of Kel- ler and Barron (1983). The effects of NH3 extend as high as Section $568-23, C C$, as indicated by the presence of middle Miocene benthic foraminifers, such as Siphogenerina basispinata. The stratigraphically higher dissolved or barren samples in this interval may also be part of the NH3 dissolution, but may represent a younger hiatus. All that remains of the probable in situ fauna is Martinottiella pallida, a lower-slope to abyssal arenaceous species which uses siliceous cement and is, therefore, more resistant to dissolution.

The biofacies distribution in the Pleistocene section of Site 568 is fairly uniform. The in situ fauna is from the lower bathyal biofacies. The only change in the biofacies pattern is the decrease in the abundance of the lower middle bathyal biofacies in Cores 568-6 to 568-1, 
Table 1. (Continued).

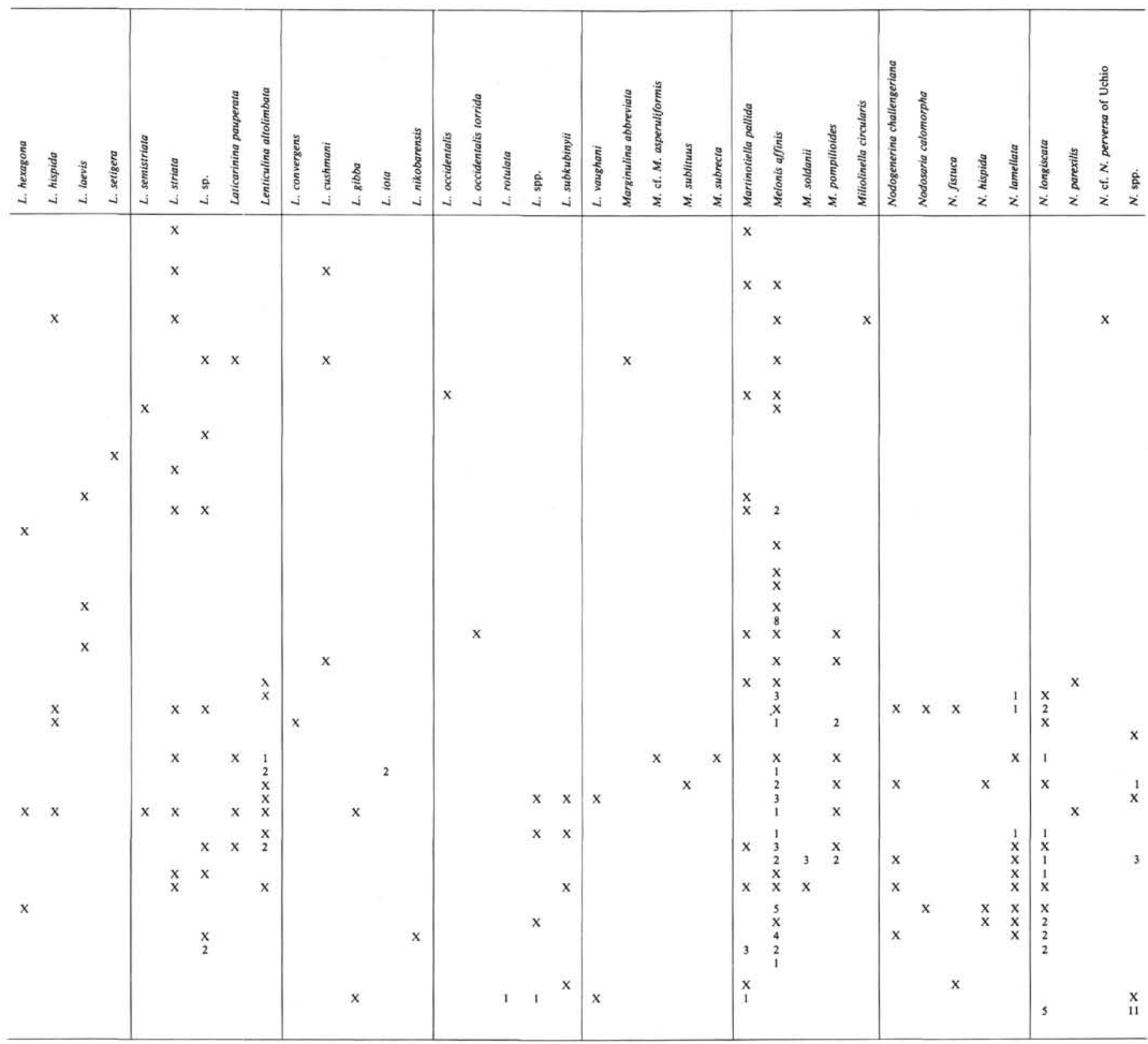

with a corresponding increase in the lower bathyal and abyssal faunas and no corresponding decrease in the shallower-water biofacies.

Transported faunas are common at Site 568. Patterns observed here are the same as at Site 570 .

\section{SITE 569}

Site 569 is $32 \mathrm{~km}$ landward of the trench axis, on the lower slope (water depth $2799 \mathrm{~m}$ ) (Fig. 1). Currently this site is in the lower bathyal biofacies and under the influence of the PDW (Fig. 2). Two holes were drilled at the site, Hole 569 (Cores 1-27) and Hole 569A (Cores H1 to 10), from which lower Eocene to Pleistocene material was recovered. Planktonic organisms place the Eocene/ Oligocene boundary in Cores 569A-5 to 569A-7. Above this boundary, age interpretations based on planktonic foraminifers indicate that there are sediments from the upper Oligocene to lower Miocene (Cores 569A-6 to 569A-H1, and 569-27 to 569-22), lower Miocene (Cores 569-20 to 569-14), middle Miocene (Cores 569-13 to 569-10), Miocene-Pliocene undifferentiated (Cores 569-9 and 569-8), lower Pliocene (the upper part of Core 569-8), and Pleistocene (Cores 569-7 to 569-1) (Filewicz, this volume; Stone and Keller, this volume). In the Oligocene to lower Miocene interval, there are numerous barren samples or samples with low diversity and low numbers of foraminifers. The age interpretations based on planktonic foraminifers and the benthic foraminiferal interpretations of the paleoceanography indicate that the dissolved or barren intervals stratigraphically higher in the 
Table 1. (Continued).

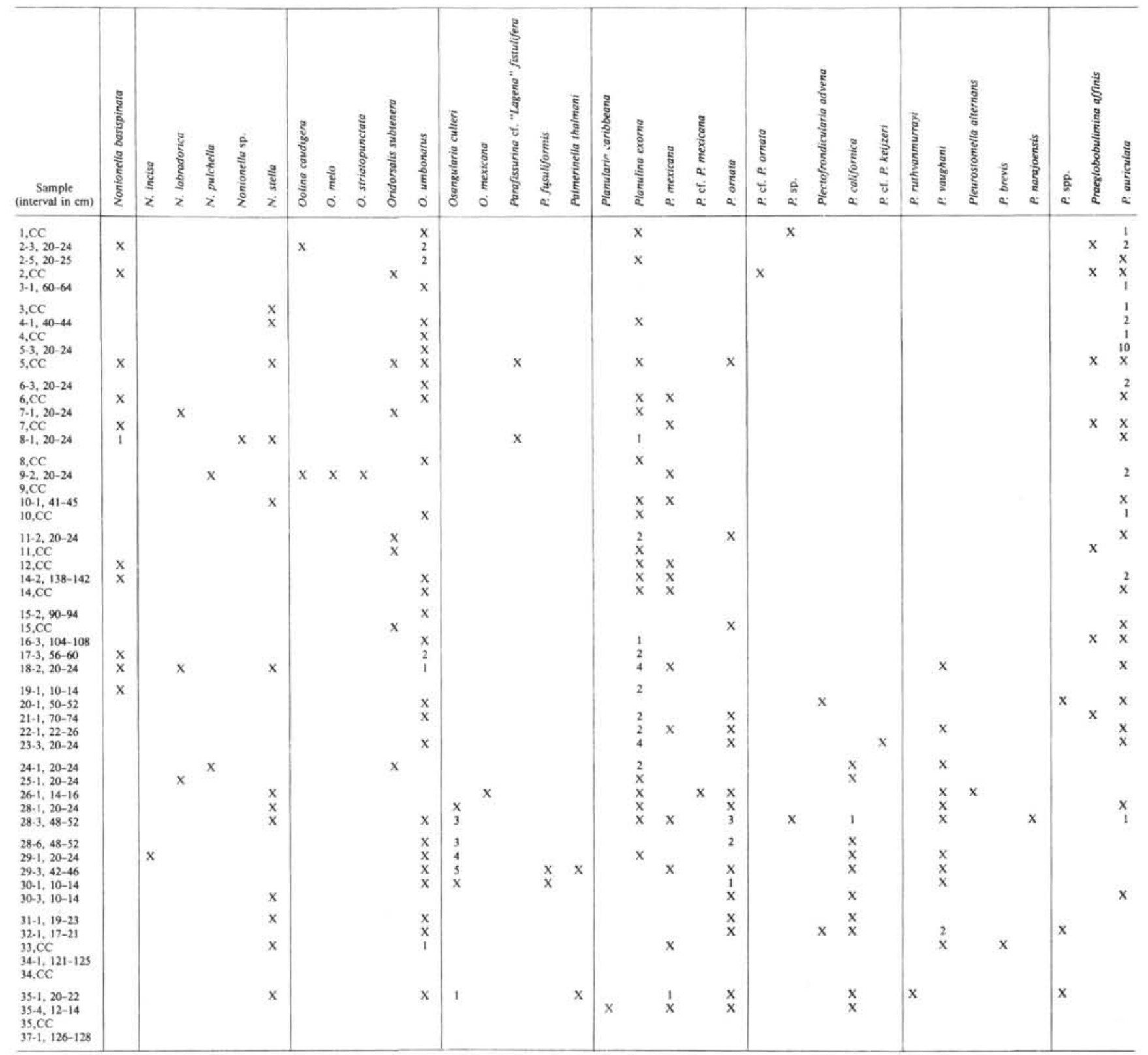

section correspond to deep-sea hiatuses NH1 (Core 569-15 to 569-17), NH2 (Core 569-12), and NH3 (Cores 569-8 and 569-9) (Fig. 3).

Biofacies analysis of Site 569 indicates that this site has fluctuated between the lower bathyal biofacies (Cores $569-14$ to $569-13$; 569-11 to 569-10; and 569-7 to 569-1) and abyssal biofacies (Cores 569A-6 to 569A-H1; 569-27 to $569-15$; $569-12$; and $569-9$ to $569-8$ ) (Fig. 6 [back pocket]; Table 3 and 4). The benthic foraminiferal assemblages also indicate that water masses influencing this area included the early Miocene bottom water, ABW, PDW, and PIW (Fig. 6 [back pocket]).

Biofacies distribution of the assemblages in Cores $569 \mathrm{~A}-6$ to $569 \mathrm{~A}-\mathrm{H} 1$ and $569-27$ to $569-24$ is very erratic, and primarily reflects the transported assemblages. Outer-shelf and upper-slope species are poorly preserved forms with heavy, robust tests. Specimens from the middle to lower slope are better preserved and have more variable shapes. Quinqueloculina venusta represents the abyssal biofacies and the in situ fauna for this interval. The thick calcite test of this species is not easily dissolved. This species also indicates the early Miocene bottom waters (Woodruff, in press). Similar abyssal, early Miocene bottom-water assemblages were seen at Site 568, and are interpreted as correlating with deep-sea hiatus $\mathrm{PH}$.

The in situ and the transported faunas in Cores 56923 to $569-21$ are similar to those in the underlying dissolution interval. The primary differences are the better preservation and an increase in the number and diversity of foraminifers. The large pulse of shelf specimens in Samples 569-21,CC, and 569-21-1, 43-47 cm contains 
Table 1. (Continued).

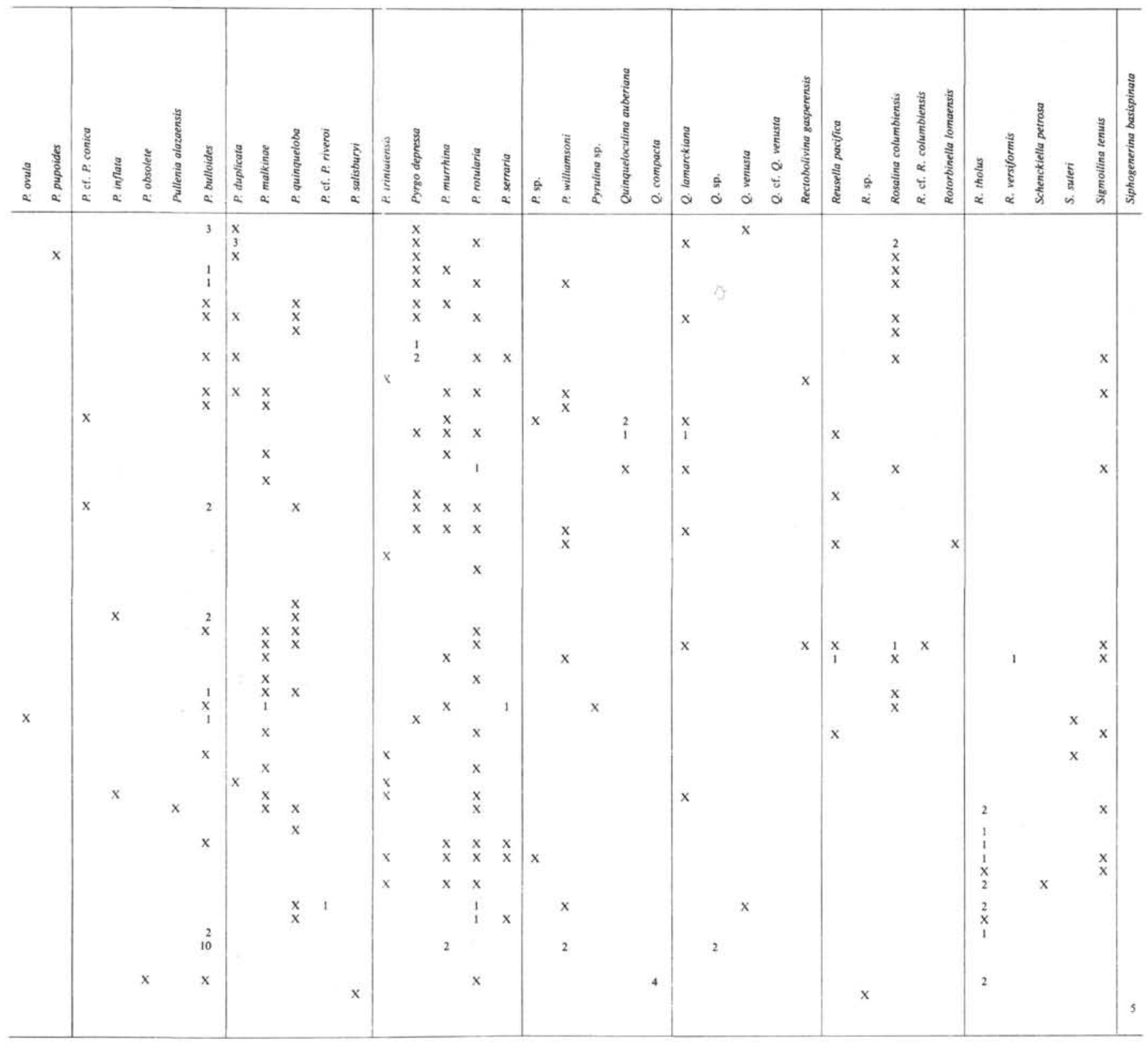

abundant Amphistegina lessonii, indicating tropical conditions and thus a general climatic warming during the early Miocene.

The abrupt shift of the biofacies and decrease in shelf and upper-slope faunas in Cores 569-20 through 569-17 suggests the presence of an unconformity or hiatus between Cores 569-20 and 569-21, or a major change in water-mass distribution, water depth currents, or sediment transport patterns. The deepest benthic foraminiferal fauna in this interval suggests that deposition occurred at lower bathyal to abyssal depths, as in the underlying samples, but the influence of an early Miocene bottom water is easily recognized because of the presence of Epistominella umbonifera, Quinqueloculina venusta, Gyroidina planulata, Pullenia quinqueloba, and species of Siphonodosaria. Many of these species are al- so associated with the AABW (Woodruff, 1979 and in press).

Biofacies patterns in Samples 569-17-1, 47-51 cm to 569-15-1, 104-108 cm suggest that deposition was at lower bathyal to abyssal depths under the influence of the early Miocene bottom water or AABW. Most of the species and trends discussed previously, for Cores 569-17 to 569-21, continue through Sample 569-15-1, 104-108 cm. Additional species such as Sigmoilina tenuis appear and further indicate the presence of the AABW. The barren or dissolved samples result from increased carbonate dissolution associated with the cooler climatic conditions, intensification of the AABW, and probably a rise in the $\mathrm{CCD}$, which occurred in the early Miocene, planktonic foraminiferal Zones N5-N6 (Bukry, 1982; Keller and Barron, 1983). Shelf and upper-slope faunas reappear in 
Table 1. (Continued).

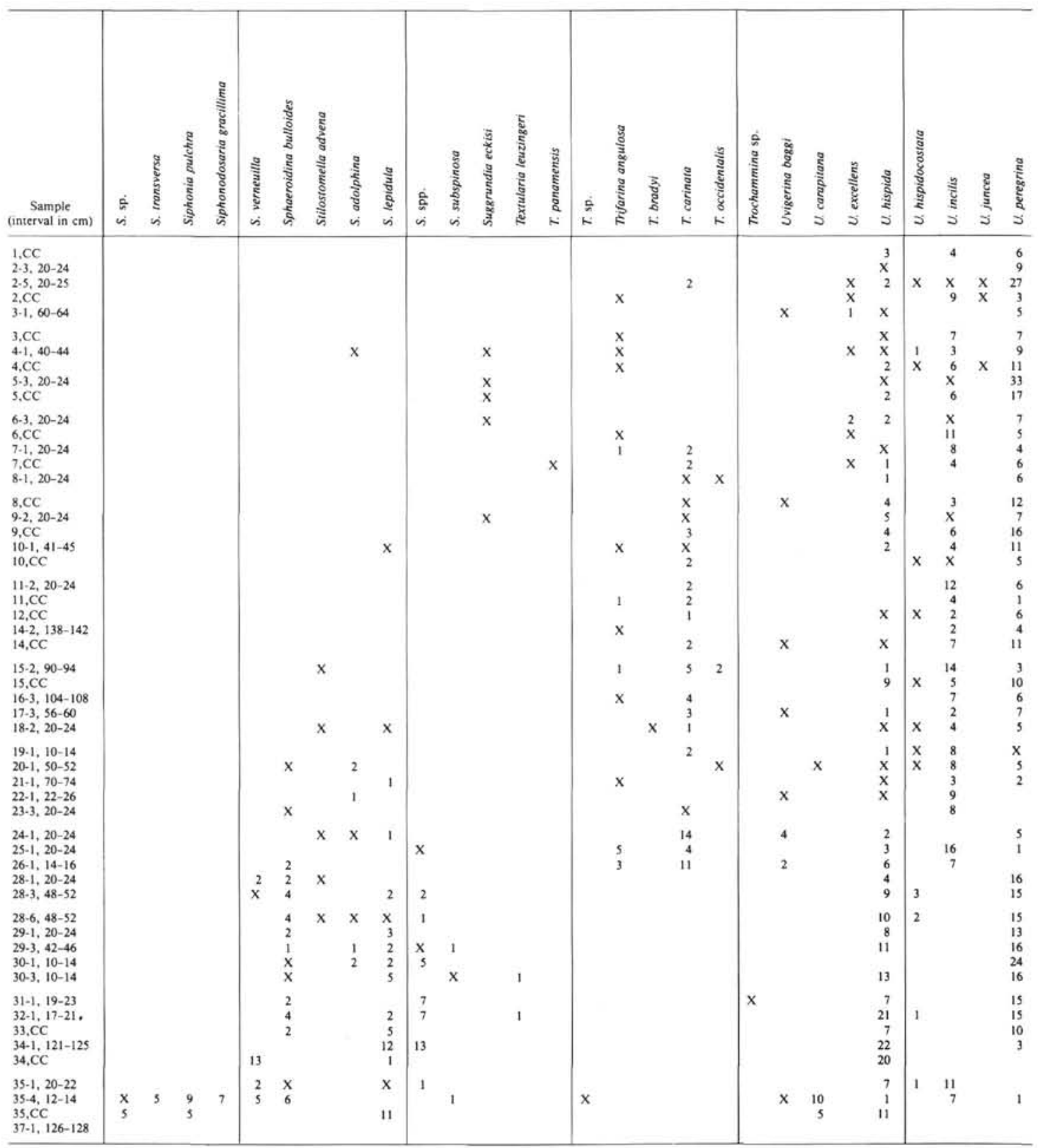

this dissolution interval, and become increasingly abundant upsection.

The change in diversity and biofacies patterns between Cores 569-15 and 569-14 may define a hiatus or unconformity, but more likely reflects a change in water depth or water mass. In Samples 569-14,CC to 569-12-5, $20-24 \mathrm{~cm}$, foraminiferal diversity and number are high, and specimens are well preserved. Transported shelf and upper-slope species become increasingly common and diverse in this interval; lenticulinids are a major component of this group. Although the lower bathyal and abyssal biofacies occur in about the same abundance, species diagnostic of the AABW decrease in abundance, and species associated with the PIW and PDW are common. Included in this last group are the species Osangularia culteri, Bulimina alazaensis, Cibicidoides bradyi,
Siphogenerina multicostata, and S. basispinata. The age of the faunas corresponds to a time of eustatic rise in sea level (Vail and Hardenbol, 1979) and generally warmer climates. The AABW is thus interpreted as having withdrawn from this part of the slope, to be replaced by the PIW and PDW masses. Tectonic activity and uplift in Central America (Weyl, 1980) could also have contributed to a decrease in water depths, as is suggested by the presence of faunas associated with shallower-water masses and dominance of species from shallower biofacies.

Planktonic foraminiferal and nannofossil ages which bracket the two barren samples in Core 569-12 indicate that this dissolution interval correlates with the NH2 hiatus observed in the deep sea (Keller and Barron, 1983). The dissolution is assumed to be the result of corrosive bottom waters. The fossiliferous sample in Core 569-12 
Table 1. (Continued).

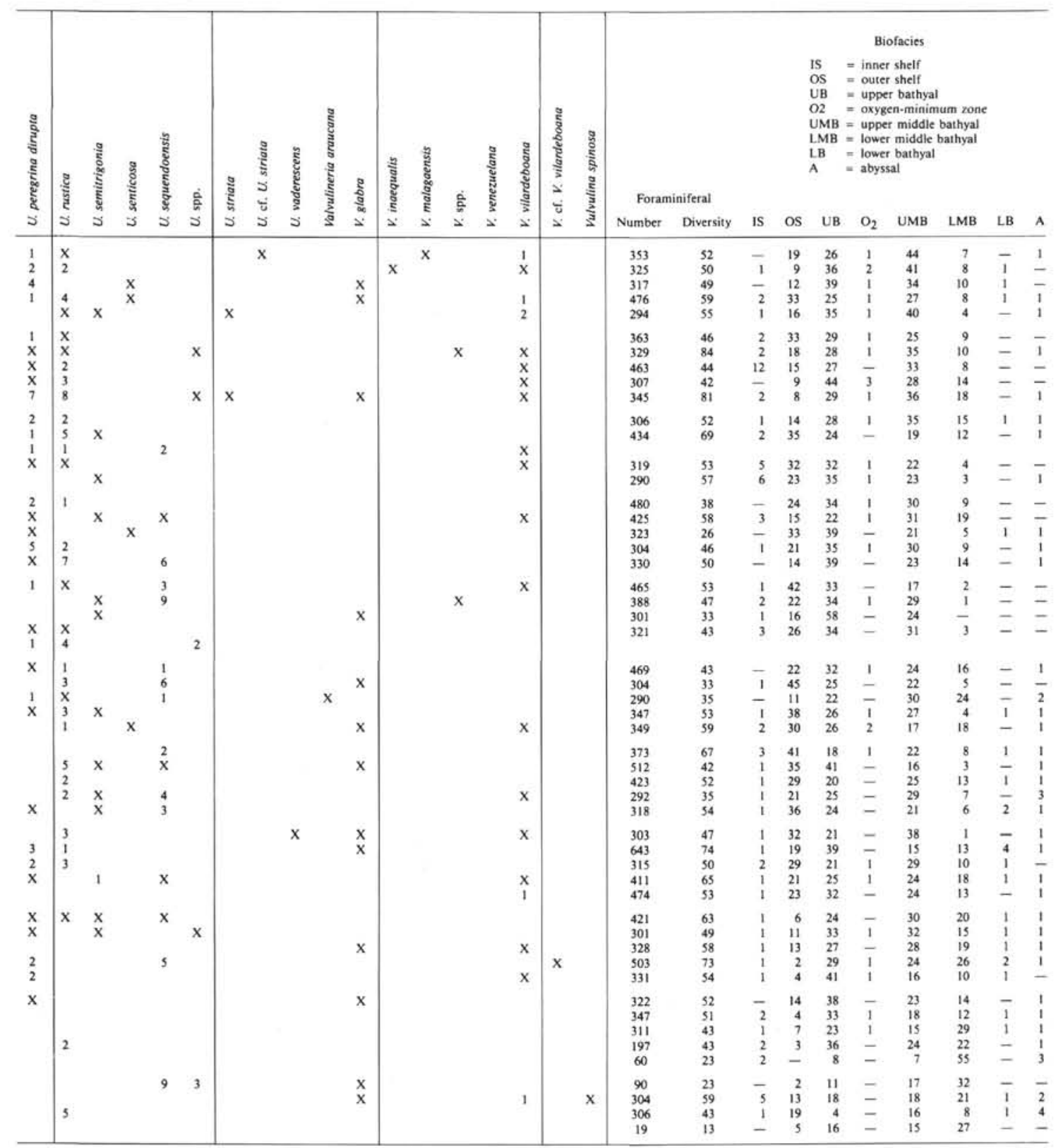

(569-12-1, 20-24 cm) contains transported shelf and slope species and no abyssal biofacies or AABW species. The shelf and slope species are assumed to be transported because of the size, shape, and condition of the foraminiferal tests: long cylindrical forms or heavy robust forms with worn or abraded tests. A similar situation was observed at Site 568, where coeval sediments contained only transported foraminiferal assemblages.

Overlying the dissolution interval, biofacies patterns indicate moderate amounts of transported shelf and upper-slope material similar to the younger lower and middle Miocene assemblages. The in situ fauna is from the lower bathyal biofacies. This fauna contains a mixture of rare abyssal AABW species-Epistominella exigua, various pleurostomellids, Anomalinoides globosus, and Gyroidina lamarkiana - and more common occurrences of species associated with the early Miocene intermediate water mass and the PIW. These species suggest that deposition occurred near the boundary between the PIW and the AABW, or under the influence of the PDW, which today is found between the PIW and the AABW.

Samples $569-8-3,18-22 \mathrm{~cm}$ to $569-9, \mathrm{CC}$ contain barren or dissolved faunas which are correlated with the deep-sea hiatus $\mathrm{NH} 3$, and possibly with a younger hiatus. The age of this dissolution is unknown, since planktonic foraminifers are absent, nannofossils are not diagnostic, and long-ranging benthic foraminifers occur in the interval with middle Miocene species below and Pliocene and younger species above. Biofacies analysis indicates that the in situ fauna is from the abyssal biofacies, and the transported faunas from the shelf and upper slope comprise less than $20 \%$ of the assemblage, where- 
Table 3. Faunal distribution, Hole 569.

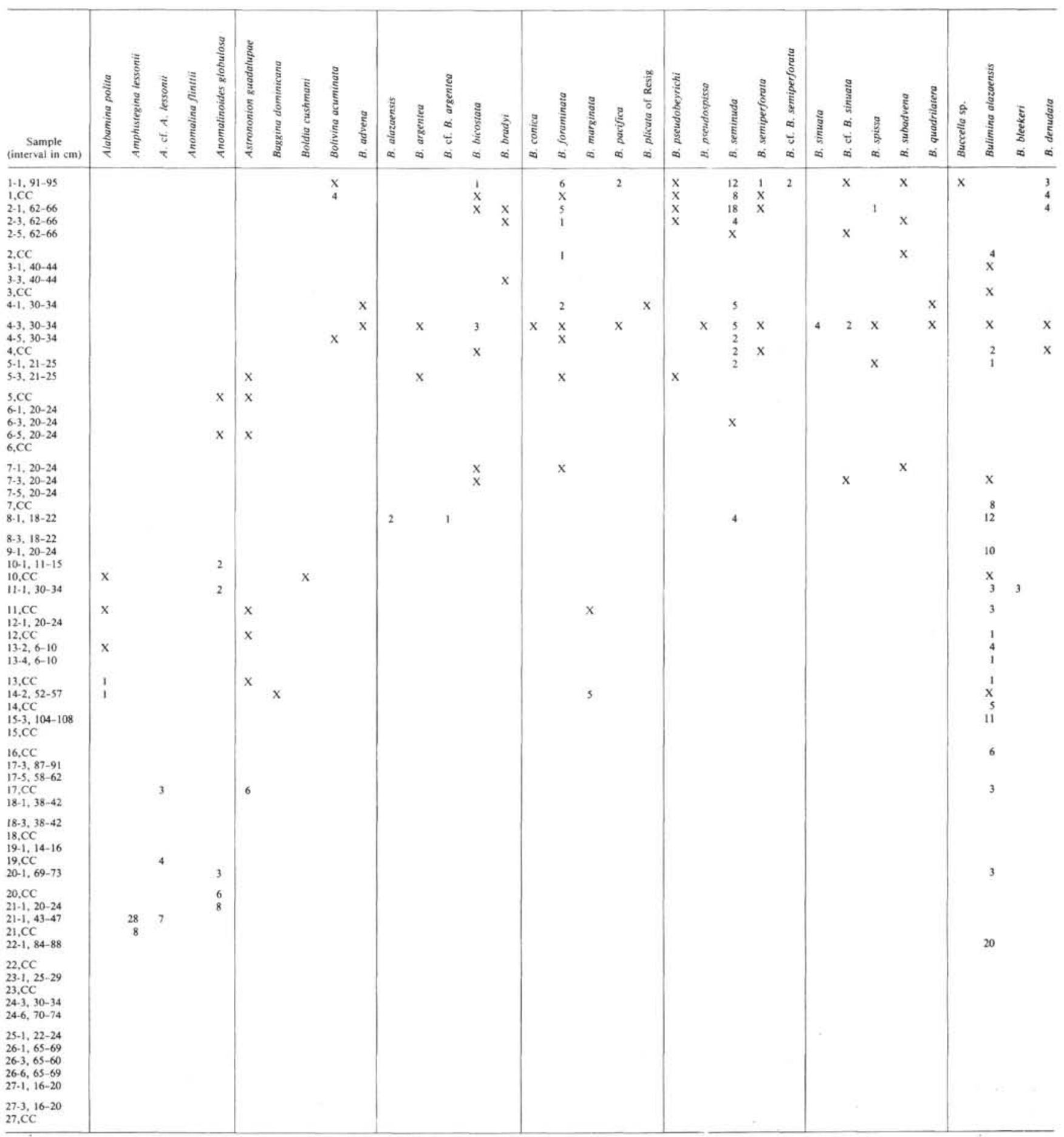

Note: Benthic foraminiferal occurrences are given as percent of the total fauna, and $X=$ less than $1 \%$. Biofacies abundances are also given in percent of the total fauna.

as transported middle- to lower-slope faunas are the dominant species. Martinottiella pallida is often the only species in the dissolved samples, indicating that deposition occurred at lower bathyal to abyssal depths under the influence of a cold corrosive water mass. This interpretation is further supported by the rare to few occurrences of Epistominella umbonifera and E. exigua and by common occurrences of Cibicidoides bradyi in the better-preserved samples, which indicate the presence of the AABW.
Biofacies patterns continue to suggest deposition at abyssal depths or no shallower than lower bathyal in Samples 569-7,CC and 569-8-1, 18-22 cm, despite the marked age difference indicated by the planktonic foraminiferal age interpretations. The abyssal depths are favored because of the presence of numerous, though not abundant, species characteristic of the AABW. Included in this group are Epistominella exigua, Laticarinina pauperata, Pleurostomella praegerontia, various gyroidinids, and Uvigerina hispida. 
Table 3. (Continued).

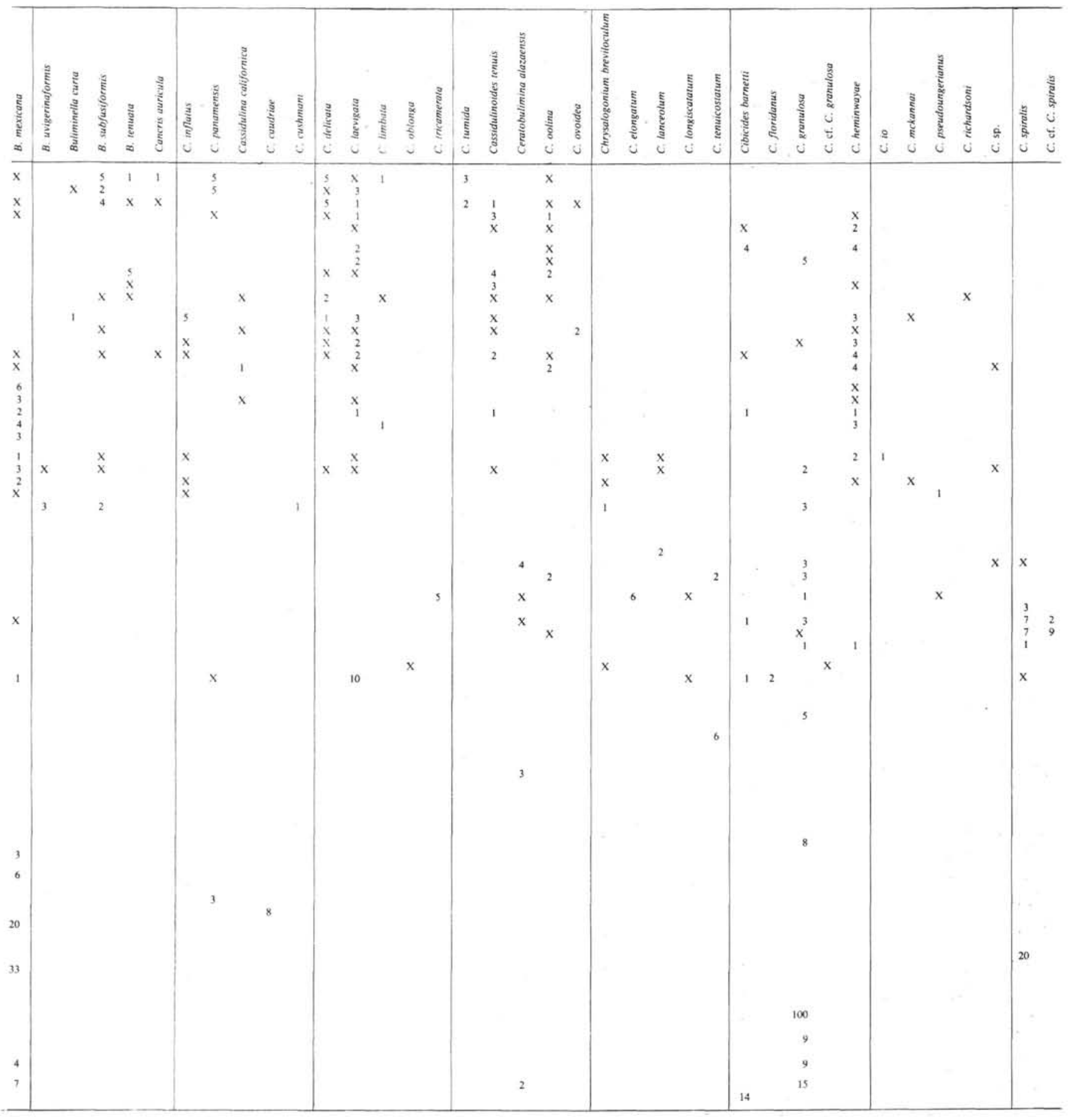

Biofacies distribution is fairly uniform in Pleistocene Cores 569-7 to 569-1. Except for an occasional pulse of transported material, shelf and upper-slope species are present in minor amounts. The major source of the transported material is the middle and lower slope. The in situ fauna is from the abyssal and lower bathyal biofacies. Species indicative of the AABW occur throughout these Pleistocene assemblages. Epistominella exigua occurs rarely in Cores 569-6 and 569-7. Uvigerina vaderes- cens, $U$. hispida, and $U$. senticosa are common to abundant in these cores, but decrease or are absent in the younger samples. In the younger samples, species diagnostic of the AABW have decreased in abundance as a result of either increased downslope transport or a slight shoaling of the site. A change in fauna occurs in Core 569-5, where $U$. vaderescens decreases sharply in abundance and $U$. peregrina increases. This change is believed to represent a slight shallowing, which would have 
Table 3. (Continued).

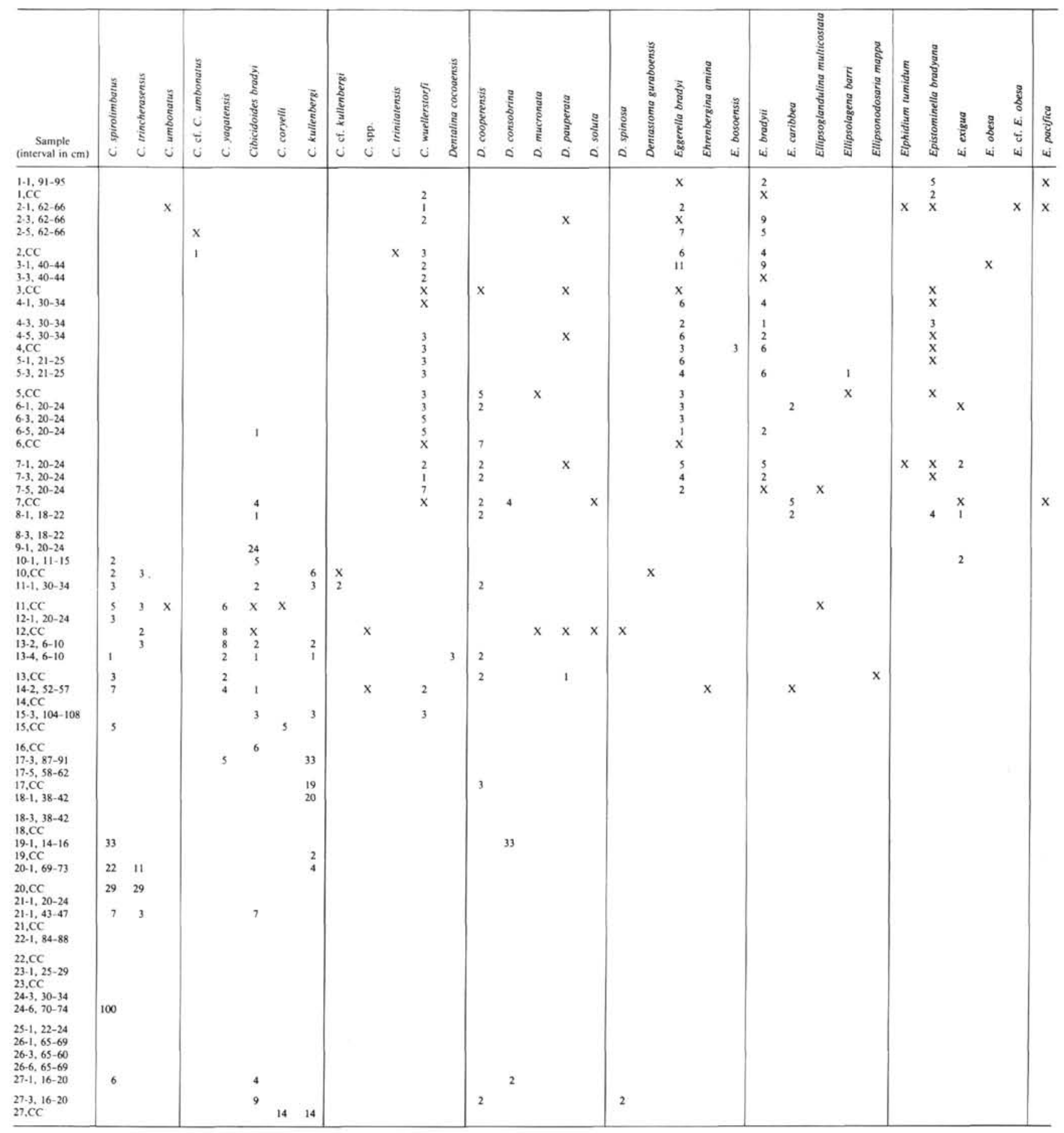

caused the faunas to be more strongly influenced by a shallower-water mass such as the PDW.

\section{SITE 566}

Site 566 lies in a canyon slightly to the south of the other Guatemalan sites. Four short holes were drilled here. Microfossils examined from three of the holes are few, poorly preserved, and seem to represent a mixture of ages. Material from the fourth hole was not examined for microfossils. Faunal lists for the fossiliferous holes are given in Table 5. The age and ecology of this site are discussed in the site chapter, and will not be considered further here.

\section{SITE 567}

Site 567 is near the base of the landward slope of the Middle America Trench, $3 \mathrm{~km}$ from the trench axis, at a water depth of $5529 \mathrm{~m}$ (Fig. 1). Presently this site is within the abyssal biofacies, and is affected by the AABW (Fig. 2). Miocene to Pleistocene sediments are recog- 
Table 3. (Continued).

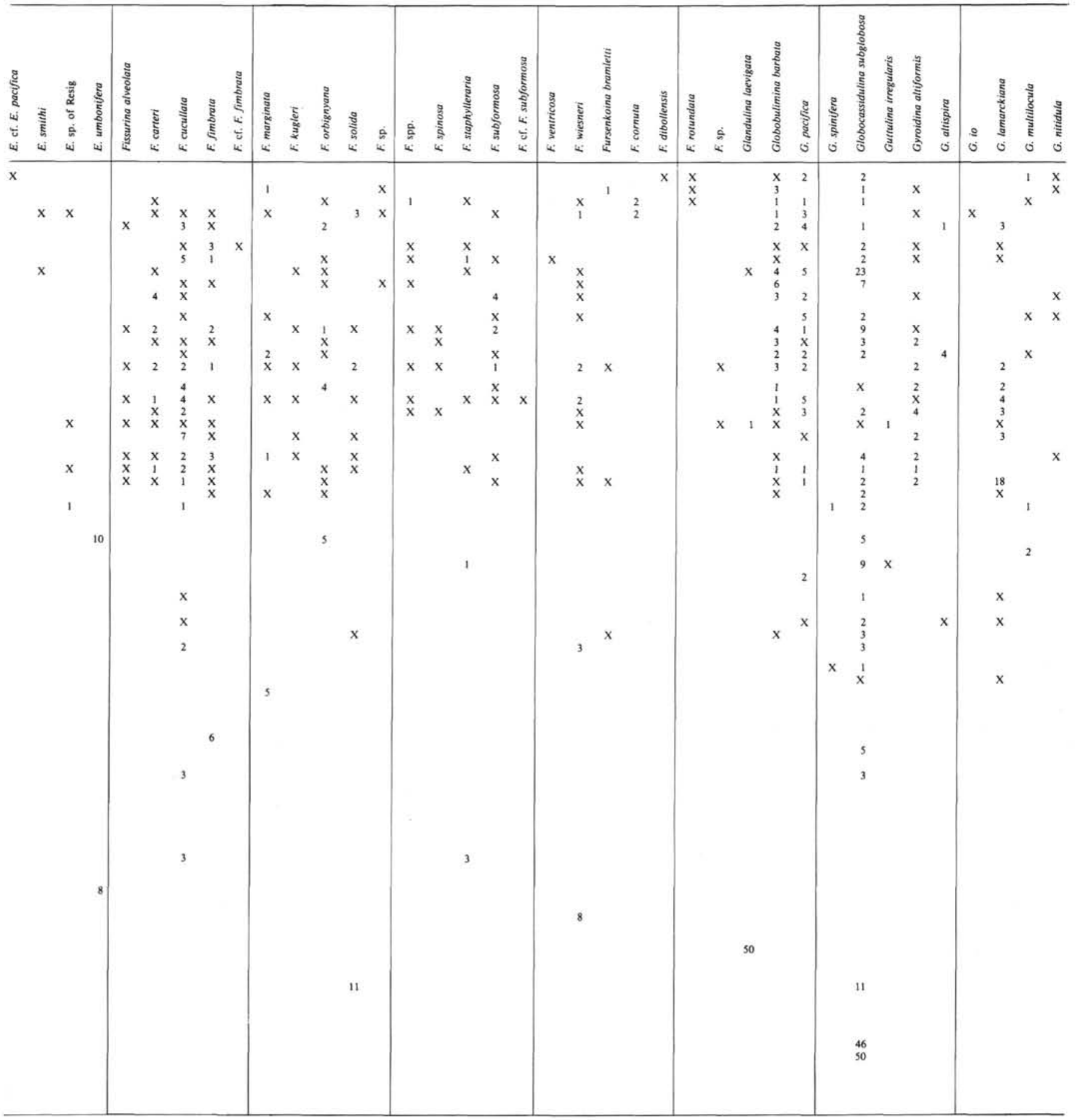

nized by the planktonic foraminifers lower Miocene (Cores 567A-13 to 567A-3), Pliocene (Cores 567A-3 to 567A-1), and Pleistocene (Cores 567-H1 and 567A-2 to 567A-H1) (Filewicz, this volume; Stone and Keller, this volume). Hole 567 and the upper cores in Hole 567A contain mixed faunas, so the age assignments are not as precise as in the Site 569 Pleistocene section. Below Core 567A-13, the section is barren of foraminifers, except for a single sample in Core 567A-19, which is Cretaceous. Extensive dissolution has occurred below Core 567A-12, and in Cores 567A-6 and 567A-7. Barren and dissolved samples are also present in Cores 567A-3 and 567A-4 (Tables 6 and 7). Planktonic foraminiferal ages suggest that the oldest interval is correlative with deep-sea hiatus $\mathrm{PH}$ and that the dissolution interval in Cores 567A-6 and 567A-7 correlates with deep-sea hiatus NH1. Middle Miocene benthic foraminifers such as Siphogenerina basispinata occur as high as Section 567A-3-6 in the young- 
Table 3. (Continued).

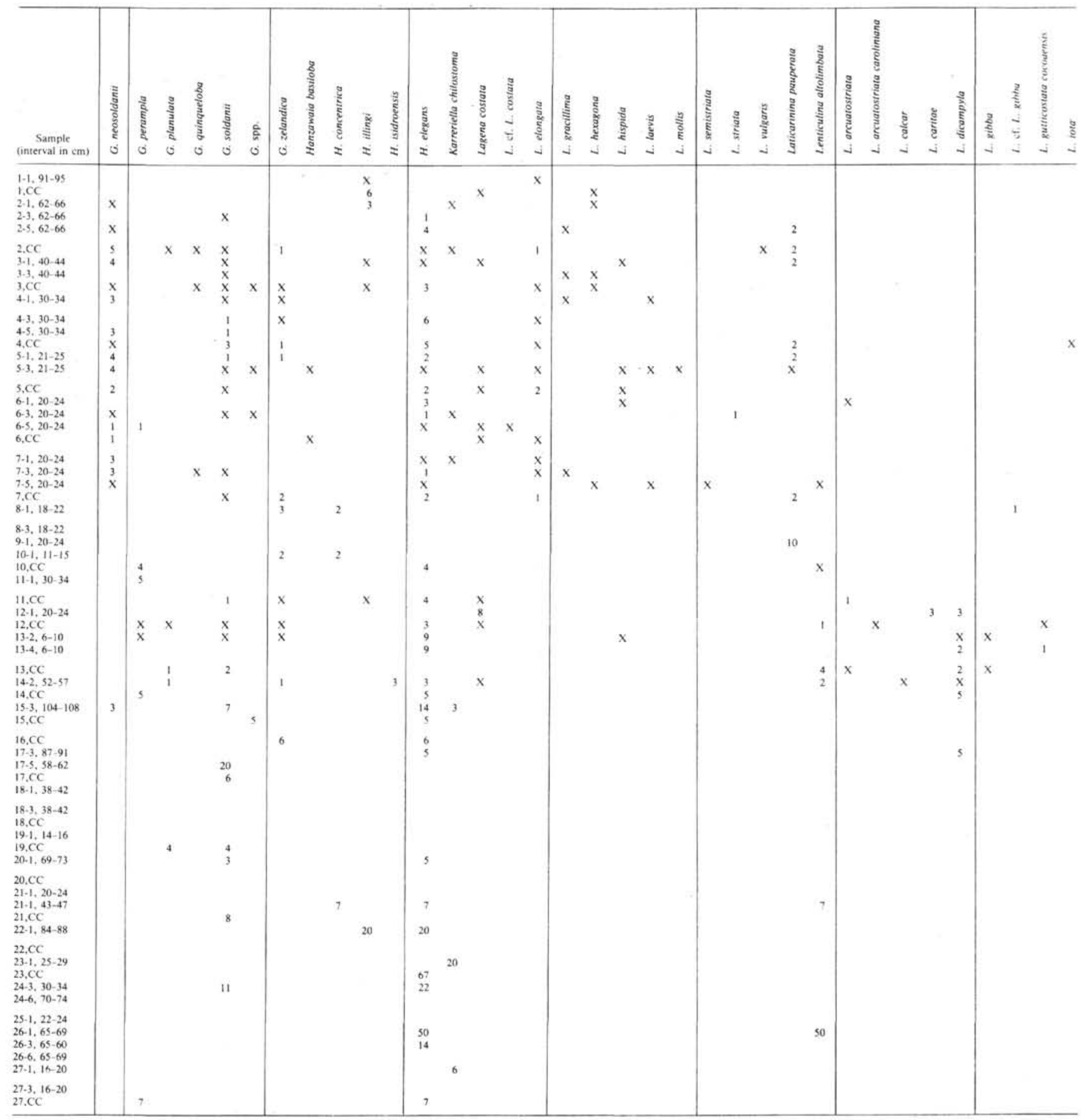

est dissolved interval (Cores 567A-4 and 567A-3). The benthic and planktonic foraminiferal ages therefore indicate that the barren and dissolved samples, from Sample $567 \mathrm{~A}-4-1,84-88 \mathrm{~cm}$ to $567 \mathrm{~A}-3-6,76-80 \mathrm{~cm}$, correlate with deep-sea hiatus NH3. The dissolved and lowerdiversity assemblages which continue to occur higher in Core 567A-3 contain a mixture of Miocene and younger species, suggesting reworking, and may therefore represent one or several Miocene through Pliocene erosional events (Fig. 3). Biofacies analysis of Site 567 indicates that deposition in both the early Miocene and in the Pliocene-Pleistocene interval has been within the abyssal biofacies and under the influence of the AABW or its early Miocene equivalent (Fig. 7 [back pocket]; Table 6).

Benthic foraminiferal assemblages (Cores 567A-12 to 567A-8) above the older dissolution interval contain few to common transported shelf and slope species, such as Globocassidulina subglobosa, various species of Lentic- 
Table 3. (Continued).

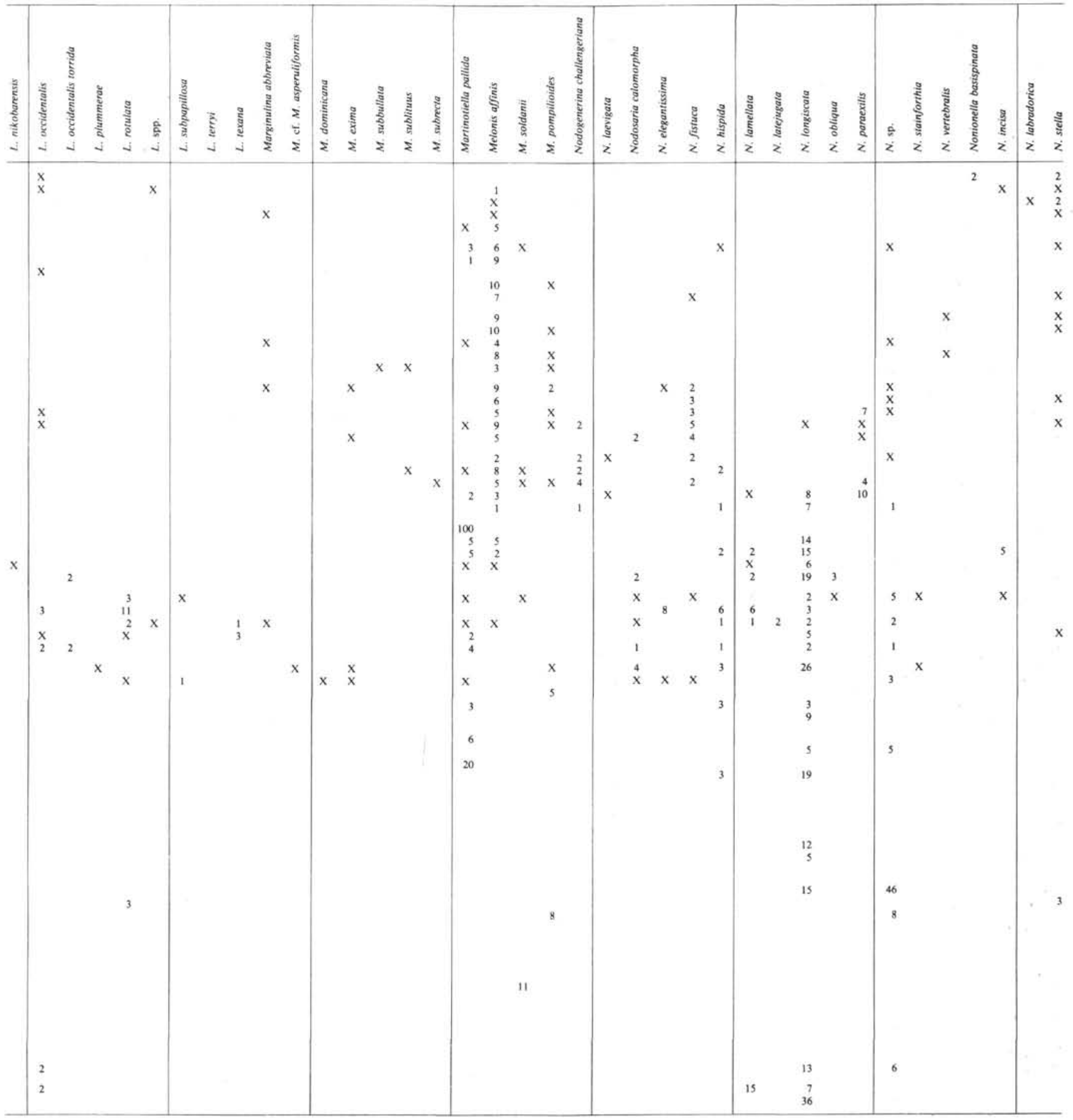

ulina, and the costate uvigerinids. All these forms have thick heavy tests, which can more easily withstand transport and dissolution. Transported middle bathyal species include many forms which are also diagnostic of the PIW, such as the siphogenerinids, Osangularia culte$r i$, and Bulimina rostrata. The in situ fauna, however, is from the lower bathyal to abyssal biofacies. Species diagnostic of the early Miocene bottom water are not abundant, but include Gyroidina planulata, Pullenia quin- queloba, Quinqueloculina venusta, Cibicidoides grimsdalei, and Laticarinina pauperata. The dominant species in these assemblages are frequently species of Siphonodosaria, Stilostomella, and Chrysalongonium, which were often associated with the early Miocene bottom water and, later, the AABW (Woodruff, in press).

Overlying the barren interval (Cores 567A-6 and 567A7), the benthic foraminiferal faunas continue to show the effects of strong dissolution: foraminiferal number 
Table 3. (Continued).

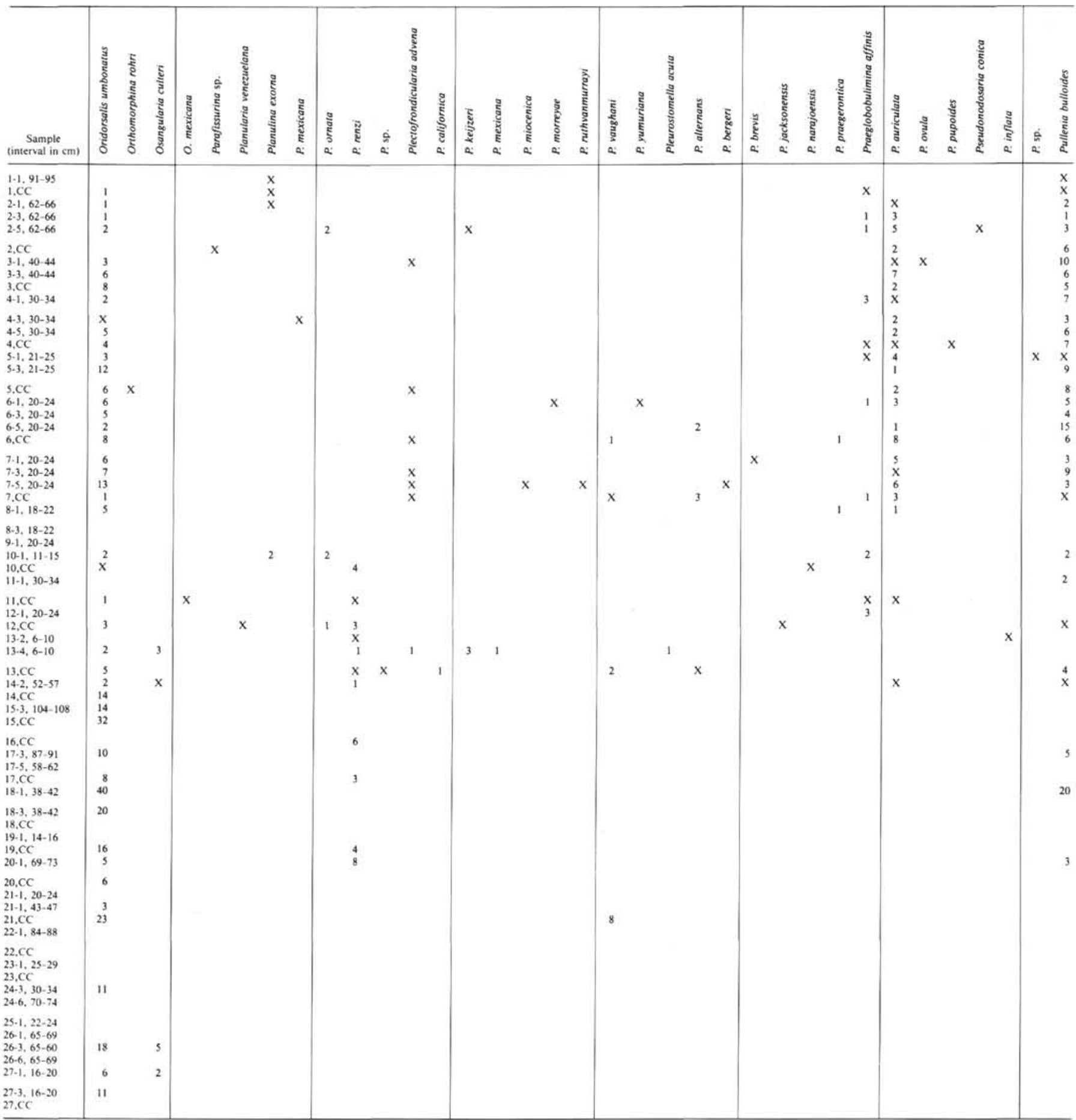

and diversity are low, and biofacies patterns indicate considerable transport from the shelf and upper slope (Core 567A-5 and the upper part of Core 567A-6). In samples $567 \mathrm{~A}-5-1,65-72 \mathrm{~cm}$ through $567 \mathrm{~A}-4-2,84-88 \mathrm{~cm}$, dissolution decreases and the benthic foraminiferal faunas reappear and are similar to those in Cores 567A-8 and 567A-9. Differences between the two faunas result from evolution and the extinction of the costate uvigerinids. Nevertheless, the faunas continue to suggest that depo- sition occurred in the abyssal biofacies and under the influence of the early Miocene bottom water. The latter interpretation is based on the presence of species already cited as being associated with early Miocene bottom water, as well as by the appearance of various species of Pleurostomella and Ehrenbergina.

Barren and dissolved samples in Core 567A-4 (Samples $567 \mathrm{~A}-4-1,84-88 \mathrm{~cm}$ to $567 \mathrm{~A}-3-2,76-80 \mathrm{~cm}$ ) and Core 567A-3 are mixed with several fossiliferous sam- 
Table 3. (Continued).

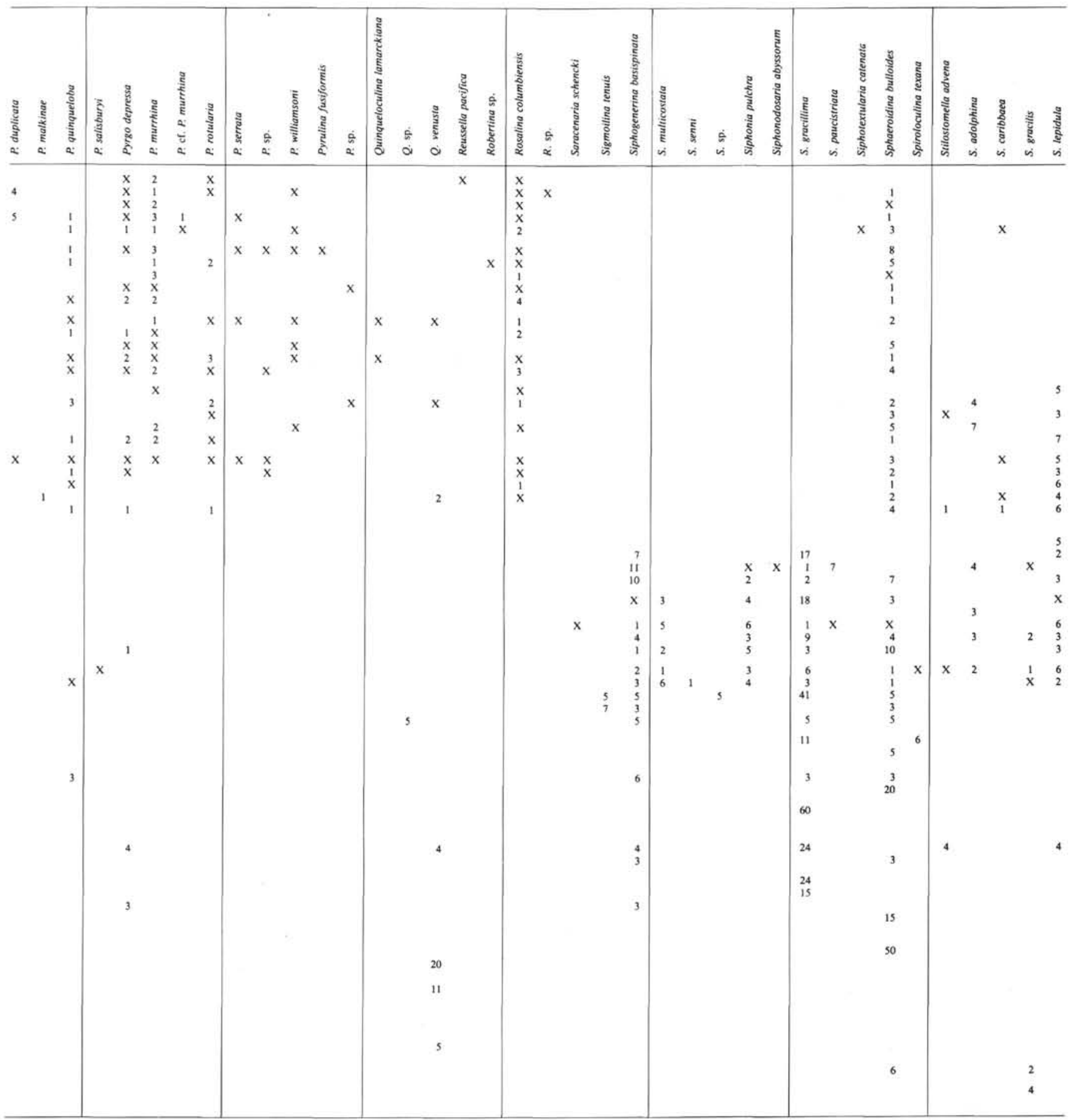

ples. Age interpretations, biofacies patterns, and species present are confusing, and suggest major reworking of faunas, possibly as the result of several erosional events. Deep-sea hiatuses NH3 through NH7 occurred during the time represented by this interval, and erosion associated with any of these events could be responsible. Benthic foraminifers present suggest that deposition occurred in the abyssal biofacies and under the influence of the AABW, but the mixed nature of the assemblage makes this interpretation unreliable.
Biofacies analysis of the foraminiferal assemblages in Samples 567A-3-1, 76-80 cm and 567A-2,CC indicate that deposition occurred in the lower bathyal to abyssal biofacies. Species indicative of a particular water mass are rare and overshadowed by species diagnostic of the shallower biofacies. AABW species present include Sigmoilina tenuis and Gyroidina planulata, which together comprise only $3 \%$ of the fauna. Nevertheless, deposition is interpreted as having occurred in the abyssal biofacies and under the influence of the AABW. 
Table 3. (Continued).

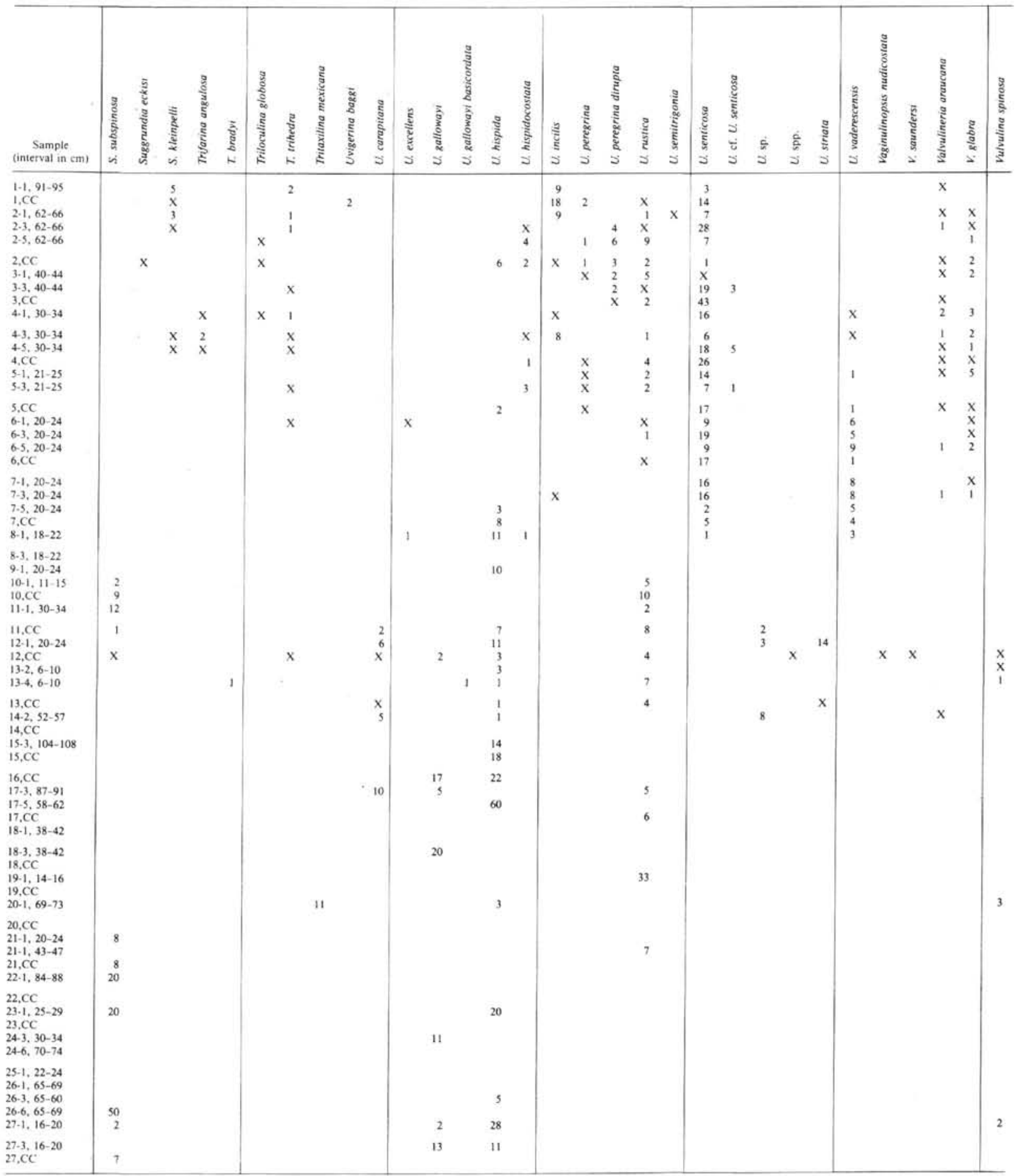

Similar low-diversity Pliocene faunas continue as high as Sample 567A-2-1, 59-63 cm, with little change other than the first occurrences of species of Bolivina, which dominate the Pleistocene faunas.

The shift in the biofacies pattern between Cores $567 \mathrm{~A}-2$ and 567A-1 may represent an unconformity or hiatus. Based on planktonic foraminiferal ages and the similarity of the benthic foraminiferal fauna, this shift is believed to represent a major slide or slump originating in the outer shelf-upper slope region, and to be Pliocene.
The change in biofacies pattern between Samples 567$1, \mathrm{CC}$ and $567-\mathrm{H} 1, \mathrm{CC}$ is correlated with the cold event (glacial) frequently associated with the Pliocene/Pleistocene boundary cold event 1.2 to $2.5 \mathrm{Ma}$ ago (Ingle 1967, 1973; Keller, 1978; Keller and Ingle, 1981). This cold event was caused by intensification of the AABW. The foraminiferal faunas immediately above the sediment record of this event are dominated by lower-slope and abyssal species, particularly Gyroidina planulata, Melonis affinis, Uvigerina hispida, and $U$. senticosa. The 
Table 3. (Continued).

\begin{tabular}{|c|c|c|c|c|c|c|c|c|c|}
\hline \multicolumn{2}{|c|}{ Foraminiferal } & \multirow[b]{2}{*}{ is } & \multirow[b]{2}{*}{ os } & \multirow[b]{2}{*}{ UB } & $\begin{array}{l}\text { Is } \\
\text { O } \\
\text { L } \\
0 \\
\text { L } \\
\text { L } \\
\text { L } \\
\text { A }\end{array}$ & $\begin{aligned} & =1 \\
& =1 \\
& =1 \\
& =0 \\
A B & =1 \\
A B & =1 \\
& =1 \\
& =\end{aligned}$ & $\begin{array}{l}\text { Bofofacic } \\
\text { ner shelt } \\
\text { ther shelt } \\
\text { per bat } \\
\text { ygen-mi } \\
\text { pper mid } \\
\text { wer mid } \\
\text { wer bath } \\
\text { wysal }\end{array}$ & $\begin{array}{l}\text { al } \\
\text { imum } \\
\text { le bat } \\
\text { le bath } \\
\text { al }\end{array}$ & $\begin{array}{l}\text { zone } \\
\text { yal } \\
\text { yal }\end{array}$ \\
\hline Number & Diversity & & & & $\mathrm{O}_{2}$ & UMB & LMB & $1 B$ & A \\
\hline 314 & 51 & 6 & 28 & 15 & 10 & 28 & 5 & 3 & 2 \\
\hline 298 & 49 & i & 45 & 8 & 1 & 17 & 6 & 14 & $i$ \\
\hline 388 & 59 & 4 & 19 & 11 & 5 & 38 & 10 & 7 & - \\
\hline 276 & 56 & 1 & 2 & 3 & 5 & 28 & $?$ & 29 & 9 \\
\hline 283 & 48 & - & 5 & 6 & 5 & 26 & 30 & 7 & 8 \\
\hline 304 & 60 & 1 & 2 & 5 & 1 & 24 & 36 & 1 & 8 \\
\hline 223 & 45 & i & i & 4 & i & 20 & 38 & 1 & 11 \\
\hline 419 & 33 & - & 3 & 23 & 12 & 23 & 14 & 23 & $i$ \\
\hline 394 & 40 & - & $i$ & 10 & $i$ & 15 & 24 & 44 & - \\
\hline 331 & 50 & 1 & 6 & 6 & 3 & 22 & 26 & 17 & 4 \\
\hline 298 & 63 & - & 19 & 14 & 6 & 26 & 18 & 7 & 2 \\
\hline 440 & 47 & 1 & 3 & 10 & 3 & 17 & 27 & 24 & 2 \\
\hline 315 & so & - & 2 & 10 & $i$ & 19 & 25 & 29 & 9 \\
\hline 267 & 52 & 1 & $i$ & 5 & 3 & 29 & 23 & is & - \\
\hline 447 & 62 & i & 3 & 4 & 4 & 24 & 23 & 8 & 8 \\
\hline 331 & 44 & - & 1 & 5 & - & 18 & 30 & 20 & 2 \\
\hline 300 & 51 & - & i & 4 & 5 & 22 & 25 & 9 & 8 \\
\hline 154 & 40 & - & $i$ & 7 & 3 & 19 & 23 & 20 & 3 \\
\hline 314 & 48 & 1 & 2 & 4 & - & 22 & 43 & 9 & 5 \\
\hline 289 & 35 & $i$ & - & 2 & 1 & 24 & 22 & 17 & 4 \\
\hline 339 & 58 & 1 & 1 & 8 & - & 19 & 22 & 16 & 9 \\
\hline 370 & 57 & - & 2 & 4 & 1 & 18 & 34 & 17 & 3 \\
\hline 407 & 50 & - & I & 5 & - & 32 & 22 & 4 & 19 \\
\hline 199 & 44 & - & $i$ & 6 & - & 13 & 30 & 6 & 13 \\
\hline 102 & 42 & 5 & $s$ & 7 & - & 20 & 35 & 1 & 4 \\
\hline 1 & 1 & - & - & - & - & - & - & - & 100 \\
\hline 21 & 11 & - & - & 5 & - & 24 & 38 & - & 14 \\
\hline 41 & 24 & 7 & 5 & - & - & 19 & 15 & - & 7 \\
\hline 139 & 36 & - & 8 & 13 & - & 12 & 22 & - & i \\
\hline 59 & 26 & - & 4 & 4 & - & 21 & 15 & - & - \\
\hline 355 & 52 & 1 & 10 & 6 & - & 9 & 19 & 1 & 1 \\
\hline 36 & 17 & - & 20 & 14 & - & 9 & iI & - & - \\
\hline 424 & 67 & 3 & 18 & - & 1 & 22 & is & 1 & 1 \\
\hline 117 & 38 & $i$ & 10 & 12 & i & 26 & is & $i$ & 2 \\
\hline 92 & 42 & - & 12 & 12 & - & 23 & 14 & - & 5 \\
\hline 202 & 49 & - & 13 & 2 & - & 9 & 18 & 4 & 1 \\
\hline 291 & 56 & - & ii & 8 & - & 29 & 7 & - & 2 \\
\hline 22 & 12 & - & 5 & 5 & - & 27 & 5 & 5 & - \\
\hline 29 & 16 & - & 7 & 14 & - & 27 & 28 & 7 & 3 \\
\hline 22 & 12 & - & 5 & - & 59 & - & - & - & - \\
\hline 18 & 12 & - & - & 6 & - & 22 & 28 & - & 6 \\
\hline 21 & 13 & + & 5 & 10 & - & 19 & 43 & - & - \\
\hline 5 & 3 & - & - & - & - & - & 60 & 20 & 20 \\
\hline 37 & .18 & 3 & 3 & 3 & - & 19 & 27 & 6 & - \\
\hline 5 & 4 & - & - & - & - & 60 & 40 & - & - \\
\hline 3 & 3 & - & - & - & - & 40 & - & - & - \\
\hline i & i & - & - & - & - & - & - & - & - \\
\hline 3 & 3 & - & - & - & - & - & 33 & - & - \\
\hline 25 & 14 & - & - & - & - & 24 & 12 & 4 & 4 \\
\hline 37 & 19 & - & - & 5 & - & 16 & iI & 3 & - \\
\hline 17 & 6 & - & - & - & - & 18. & - & - & - \\
\hline 13 & 5 & - & - & - & - & 8 & - & - & 8 \\
\hline 29 & 15 & 45 & 14 & 7 & - & 15 & $?$ & - & - \\
\hline 13 & 10 & 8 & - & - & - & 38 & 8 & 8 & $I$ \\
\hline 15 & 5 & - & 20 & 20 & - & 20 & 20 & - & - \\
\hline 2 & 2 & - & - & - & - & 100 & - & - & - \\
\hline 5 & 5 & - & 20 & 20 & - & 20 & 20 & - & - \\
\hline 3 & 2 & - & - & 67 & - & 33 & - & - & - \\
\hline 9 & 8 & - & - & 33 & - & 22 & 11 & 11 & 11 \\
\hline 3 & 1 & - & - & - & - & - & - & - & - \\
\hline 1 & 1 & - & - & - & - & - & - & - & - \\
\hline 2 & 2 & - & 50 & 50 & - & - & - & - & - \\
\hline 22 & 7 & - & - & 59 & - & 23 & 5 & - & 3 \\
\hline 2 & 2 & - & - & 50 & - & - & - & - & - \\
\hline 54 & 17 & - & - & - & - & 23 & 28 & - & \\
\hline 46 & 13 & - & 2 & - & - & 40 & 11 & - & - \\
\hline 14 & $\quad 7$ & - & - & 7 & - & - & 14 & - & - \\
\hline
\end{tabular}

first two of these species are associated with the AABW in the Miocene (Woodruff, in press). Thus, deposition of this Pleistocene interval was in the abyssal biofacies and under the influence of the AABW.

\section{PALEOCEANOGRAPHIC INTERPRETATION}

The early Miocene of the Middle America slope off Guatemala was characterized by improved preservation of the benthic foraminiferal assemblages, increased foraminiferal diversity, decreased influence of the bottom waters, and decreased water depths. After a period of nondeposition, or erosion and dissolution, in the Oligocene (Thompson, 1982), sediments began accumulating at the base of the slope (lower bathyal biofacies, Fig. 8). Corrosive early Miocene bottom waters initially prevented the accumulation of calcium carbonate, so that the in situ faunas were rarely preserved, and transported upper-slope and shelf faunas are only occasionally preserved. As climatic conditions stabilized, the corrosive nature of this bottom water decreased, downslope transport decreased, and both the transported and in situ faunas were preserved. Increased dissolution followed this brief period of stabilization, and is correlated with deep-sea hiatus NH1, a major cold event, eustatic lowering of sea level, and a global increase in corrosive bottom waters during the early Miocene (Vail and Hardenbol, 1979; Bukry, 1982; Keller and Barron, 1983).

Benthic foraminiferal faunas characteristic of the deep central Pacific bottom water, which first appeared at Site 570 between 18 and $20 \mathrm{Ma}$ ago (NH1 hiatus), migrated downslope and appeared at Sites 568 and 569 between 18 and $15 \mathrm{Ma}$ ago (Fig. 8). These faunal occurrences represent the first appearance of this new dense bottom water on the Middle America slope, and indicate the presence of a deep-water corridor and presumably a deep-water connection between the Caribbean and the Pacific, as well as the restriction of cold bottom waters to greater depths. Species associated with the early Miocene intermediate water mass are also common to abundant in these assemblages; therefore, deposition probably occurred near the interface between the two water masses. Alternatively, this mixture of assemblages may indicate that the interface between the two water masses was poorly defined because the oceans were not well stratified at this time, and a distinct low-oxygen PIW may not have developed yet, as also suggested by Woodruff (in press). In addition to water-mass changes, benthic foraminifers indicate that the water depth decreased and downslope transport increased. These faunal changes coincide with uplift in Central America, and probably indicate initiation of the closure of the deep marine connection across Panama (van Andel et al., 1975; Weyl, 1980; Keller and Barron, 1983). The shallow-water connection with the Caribbean still exists numerous species with Caribbean affinities appear in the transported upper-shelf and slope assemblages. Predicted warmer temperatures (Douglas and Savin, 1973) are reflected by the high diversity of the benthic foraminifers.

The increased number of deep-sea hiatuses in the middle Miocene is evident on the Middle America slope, where this interval is characterized mostly by missing sections and numerous dissolved intervals. Dissolution at Sites 568 and 569 correlates with $\mathrm{NH} 2$ and $\mathrm{NH} 3$ and the expansion of the corrosive bottom waters. Hiatus $\mathrm{NH} 2$ is not well represented in these sections. Benthic foraminiferal faunas overlying the $\mathrm{NH} 2$ dissolution are relatively unchanged from the underlying upper lower Miocene faunas, suggesting a continuation of the warm surface waters. An increase in transported material and further decreases in the water depth suggest that uplift in Central America continued and at least a shallow wa- 
ter connection was maintained with the Caribbean. Benthic foraminiferal faunas associated with expanded bottom waters and the $\mathrm{NH} 3$ hiatus are characteristic of the AABW. Benthic foraminiferal faunas overlying the $\mathrm{NH} 3$ dissolution interval at Site 570 are characteristic of a low-oxygen PIW. These interpretations and the middle Miocene foraminiferal changes corroborate the occurrence of several major paleoceanographic events: (1) development of the AABW and PIW masses, (2) closure of the intermediate and deep-water connection across the isthmus of Panama, and (3) the establishment of modern water masses and circulation patterns.

The late Miocene is represented only at Site 570, where its sediments are characterized by faunas associated with the PIW (Fig. 8). Transported material is moderately well preserved and fairly consistent in abundance, and contains decreasing abundances of species with Caribbean affinities. The latter characteristic implies both a decline in temperatures and a restriction in the shallow water connection with the Caribbean. Expansion of the AABW interrupted this pattern only once during this period, and the resulting dissolution is correlated with NH5. Erosion associated with deep-sea hiatus $\mathrm{NH} 7$ and the Miocene/Pliocene boundary appears to have affected all sections on the slope, and is probably responsible for much of the missing sediments at Sites 567, 568, 569, and 570 .

Pliocene faunas and sediments are rare, and occur only in the lower-slope sites (Sites 567 and 569; Fig. 8). The strongly dissolved faunas indicate the presence of a corrosive AABW.

Pleistocene sediments are characterized by a general reduction in the AABW, decrease in water depths, and development of the present water-mass configuration on the Middle America margin. Variation in the benthic fo. raminiferal diversity and biofacies trends suggests glacial-interglacial cycles. The oldest glacial cycle recognized in these Pleistocene faunas corresponds to the cold event dated at 1.2 to $2.5 \mathrm{Ma}$ ago. Lower Pleistocene faunas on the lower slope (Sites 567, 569, and 568) are dissolved as a result of the expansion of the AABW during the glacial maxima. The effect of this water mass decreases markedly between Sites 568 and 570 . Site 570, which is interpreted as having been under the influence of the PDW and PIW at this time, contains only rare specimens which could be associated with any deeper water masses.

Although the AABW undoubtedly expanded and impinged on the shallower parts of the slope during the glacial or cold intervals, this water mass appears to have been progressively confined to deeper parts of the slope, finally affecting only the abyssal biofacies. A similar trend occurs in the benthic foraminiferal faunas associated with the PIW and the PDW. Progressive downslope movement of faunas and water masses may have resulted from the contraction of the AABW and a general warming of the climatic conditions in the latter part of the Pleistocene. Uplift of the continental margin and a corresponding decrease in the water depths could also have produced a similar change. The combined effect of some or all of these possibilities resulted in a distribution of benthic foraminiferal biofacies, water masses, and water depths which approximated those of the present (Fig. 2).

\section{CONCLUSIONS}

Benthic foraminiferal assemblages indicate that each of the Middle America sites considered has been on the landward side of the trench since the early Miocene and has been subjected to a nearly continuous reign of shelf and upper-slope material. These faunas also indicate that water depths on the slope sites have generally decreased from the early Miocene to the present. Deviations from this shallowing trend include the shallow water depths indicated for the late early to early middle Miocene (Fig. 8). Water masses affecting the margin included an early Miocene bottom water, a deep Pacific bottom water, early Miocene intermediate water, Antarctic Bottom Water, Pacific Deep Water, and Pacific Intermediate Water. Periods of erosion or nondeposition are responsible for gaps in the lower Miocene at Sites 567 and 570, the middle upper Miocene at Site 567, and the Pliocene at each of the sites. Dissolution was common at all sites in the early Miocene, early middle Miocene, early Pliocene, and early Pleistocene. These periods of dissolution and erosion can be directly correlated with deep-sea hiatuses and expansion of the corrosive bottom waters. Benthic foraminiferal assemblages and biofacies analysis provide clues to the development of a stratified ocean leading to the present water-mass distribution, the uplift in Central America, the closure of the deep-water connection across Panama, and the later shallow-water closing of this connection.

\section{ACKNOWLEDGMENTS}

I thank John Barron and Peter Thompson for critically reviewing the manuscript and offering valuable suggestions, and Greta Keller for invaluable discussions on Miocene paleoceanography and for critically reviewing the manuscript. Special thanks are given to Christeen Cochram for assistance during all phases of the research.

\section{REFERENCES}

Bandy, O. L., 1956. Ecology of Foraminifera in northeastern Gulf of Mexico, Prof. Pap. U.S. Geol. Surv., 274-G:179-204.

1972. Neogene planktonic foraminiferal zones, California and some geologic implications. In Lipps, J. H. (Ed.), Eastern Pacific Plankton Biostratigraphy and Paleocology. Paleogeogr., Paleoclimatol., Paleoecol., 12:1-131.

Bandy, O. L., and Arnal, R. E., 1957. Distribution of Recent Foraminifera off west coast of Central America. Am. Assoc. Petrol. Geol. Bull., 41:2927-2053.

Blow, W. H., 1969. Late middle Eocene to Recent planktonic foraminiferal biostratigraphy. In Brönnimann, P., and Renz, H. H. (Eds.), Proc. First Planktonic Conf.: Leiden (E. J. Brill), pp. 199-422.

Bukry, D., 1982. Cenozoic silicoflagellates from offshore Guatemala, Deep Sea Drilling Project Site 459. In Aubouin, J., von Huene, R., et al. Init. Repts. DSDP, 67: Washington (U.S. Govt. Printing Office), 425-446.

Burke, S. C., 1981. Recent benthic Foraminifera of the Ontong-Java Plateau. J. Foram. Res., 11:1-19.

Cadet, J. P., Pauclet, A., Thisse, Y., Berdintzeff, J. M., and Azema, J., 1982. Middle America Neogene explosive volcanism and ash layers: evidence from the Middle America Trench transect, Deep Sea Drilling Project Leg 67. In Aubouin, J., von Huene, R., et al., Init. Repts. DSDP, 67: Washington (U.S. Govt. Printing Office), 475-492.

Corliss, B. H., Honjo, S., 1981. Dissolution of deep-sea benthic Foraminifera, Micropaleontology., 27:356-378. 
Cushman, J. A., 1922. The foraminifera of the Atlantic Ocean; Part 3-Textulariidae. U.S. Nat. Mus. Bull., 104:1-149.

Douglas, R. G., 1979. Benthic foraminiferal ecology and paleoecology: a review of concepts and methods. In Lipps, J. H., Berger, W. H., Buzas, M. A., et al. (Eds.), Foraminiferal Ecology and Paleoecology: Tulsa (Soc. Econ. Paleontol. Mineral.), SEPM Short Course No. 6, pp. 21-53.

1981. Paleoecology of continental margin basins: a modern case history from the borderland of southern California. In Douglas, R. G., Colburn, I. P., and Gorsline, D. S. (Eds.), Depositional Systems of Active Continental Margin Basins: Short Course Notes: Los Angeles (Pacific Sec. Soc. Econ. Paleontol. Mineral.), pp. 121-156.

Douglas, R. G., and Heitman, H. L., 1979. Slope and basin benthic foraminifera of the California borderland. In Doyle, L. J., and Pilkey, O. H. (Eds.), Geology of Continental Slopes. Soc. Econ. Paleontol. Mineral. Spec. Publ., 27:231-246.

Douglas, R. G., and Savin, S. M., 1973. Oxygen and carbon isotope analysis of Cretaceous and Tertiary foraminifers from the central North Pacific. In Winterer, E. L., Ewing, J. I., et al., Init. Repts. DSDP, 17: Washington (U.S. Govt. Printing Office), 591-605.

Douglas, R. G., and Woodruff, F., 1981. Deep sea benthic foraminifera. In Emiliani, C. (Ed.) The Sea, (Vol. 7): New York (Interscience), 1233-1327.

Golik, A., and Phleger, F. B., 1977. Benthic Foraminifera from the Gulf of Panama. J. Foram. Res., 7:83-99.

Ingle, J. C., Jr., 1967. Foraminiferal biofacies variation and the Miocene-Pliocene boundary in southern California. Am. Paleontol. Bull., 52:217-394.

1973. Neogene Foraminifera from the northwestern Pacific Ocean, Leg 18, DSDP. In Kulm, L. D., von Huene, R., et al., Init. Repts. DSDP, 18: Washington (U.S. Govt. Printing Office), 517-567.

1980. Cenozoic paleobathymetry and depositional history of selected sequences within the southern California continental borderland. In Sliter, W. V. (Ed.), Studies in Marine Micropaleontology and Paleoecology: A Memorial Volume to Orville L. Ban$d y$. Cushman Found. Foram. Res. Spec. Pub., 19:163-195.

Ingle, J. C., Jr., and Keller, G., 1980. Benthic foraminiferal biofacies of Western Pacific Margin between $40^{\circ} \mathrm{S}$ and $32^{\circ} \mathrm{N}$. In Field, M. E., Douglas, R. G., Bouma, A. H., et al. (Eds.), Quarternary Depositional Environments of the Pacific Coast: Pacific Coast Paleogeography, Symposium 4: Los Angeles (Pacific Sec. Soc. Econ. Paleontol. Mineral.), pp. 341-355.

Keller, G., 1978. Late Neogene planktonic foraminiferal biostratigraphy and paleoecology of the northwestern Pacific: evidence from DSDP Sites 173 and 310 at the North Pacific Front. J. Foram. Res., 8:332-349.

Keller, G., and Barron, J. A., 1983. Paleoceanographic implications of Miocene deep sea hiatuses. Geol. Soc. Am. Bull., 94:590-613.

Keller, G., and Ingle, J. C., Jr., 1981. Planktonic foraminiferal biostratigraphy, paleoceanographic implications, and deep sea correlations of the Plio-Pleistocene Centerville Beach Section, Northern California. Spec. Pap. Geol. Soc. Am., 184:127-136.

Kennett, J. P., Houtz, R. E., Andrews, P. B., Edwards, A. R., Gostin, V. A., et al., 1973. Cenozoic paleoceanography in the southwest Pacific Ocean, Antarctic glaciation, and the development of the Circum-Antarctic Current. In Creager, J. S., Scholl, D. W., et al. Init. Repts. DSDP, 19: Washington (U.S. Govt. Printing Office), 1155-1170.

Kent, D., Opdyke, N. D., and Ewing, M., 1971. Climatic change in the North Pacific using ice rafted detritus as a climatic indicator. Geol. Soc. Am. Bull., 82:2741-2754.

Lohmann, G. P., 1978. Abyssal benthonic foraminifera as hydrographic indicators in the western South Atlantic Ocean. J. Foram. Res., 8: 6-34.

Loeblich, A. R., Jr., and Tappan, H., 1953. Studies of Arctic Foraminifera. Smithson. Misc. Collect., 121:1-143.

McDougall, K., 1982. Microfaunal analysis of late Quaternary deposits of the northern Bering Sea. Geol. Mijnbouw, 61:19-27.

Murray, J. W., 1973. Distribution and Ecology of Living Benthic Foraminiferids: New York (Crane, Russakand Co., Inc.).

Olsson, R. K., 1974. Pleistocene paleoceanography and Globigerina pachyderma (Ehrenberg) in Site 36, DSDP, northwestern Pacific. J. Foram. Res., 4:47-60.
Pflum, C. E., and Frerichs, W. E., 1976. Gulf of Mexico deep water foraminifers. Cushman Found. Foram. Res. Spec. Publ., 14.

Phleger, F. B., 1960. Ecology and Distribution of Recent Foraminifera: Baltimore (Johns Hopkins Press).

Poag, C. W., 1981. Ecologic Atlas of Benthic Foraminifera of the Gulf of Mexico: Woods Hole (Marine Science Internat.).

Resig, J. M., 1981. Biogeography of benthic Foraminifera of the northern Nazca Plate and adjacent continental margin. Mem. Geol. Soc. Am., 154:619-665.

Shackleton, N. J., and Kennett, J. P., 1975. Paleotemperature history of the Cenozoic and the initiation of Antarctic glaciation: oxygen and carbon isotope analysis in DSDP Sites 277,279 , and 281 . In Kennett, J. P., Houtz, R. E., et al., Init. Repts. DSDP, 29: Washington (U.S. Govt. Printing Office), 743-755.

Shackleton, N. J., and Opdyke, N. D., 1977. Oxygen isotope and paleomagnetic evidence for early Northern Hemisphere glaciation. Nature, 270:216-219.

Seely, D. R., Vail, P. R., and Walton, G. G., 1974. Trench slope mode. In Burke, C. A., and Drake, C. L., (Eds.), The Geology of Continental Margins: New York (Springer Verlag), pp. 249-260.

Smith, P. B., 1964. Ecology of benthonic species. Prof. Pap. U.S. Geol. Surv., 429-B:B1-B55.

1973. Foraminifera of the North Pacific Ocean. Prof. Pap. U.S. Geol. Surv., 766:1-27.

Streeter, S. S., 1972. Living benthonic foraminifera of the Gulf of California, a factor analysis of Phleger's (1964) data. Micropaleontology, 18:64-73.

1973. Bottom water and benthonic foraminifera in the North Atlantic-glacial-interglacial contrasts. Quat. Res., 3:131-141.

Thompson, P. R., 1982. Foraminifers of the Middle America Trench. In Aubouin, J., von Huene, et al., Init. Repts. DSDP, 67: Washington (U.S. Govt. Printing Office), 351-381.

Uchio, T., 1960. Ecology of living benthonic foraminifera from San Diego, California area. Cushman Found. Res. Spec. Publ., 5: $1-71$.

Vail, P. R., and Hardenbol, J., 1979. Sea-level changes during the Tertiary. Oceanus, 22:71-79.

van Andel, T. H., Heath, G. R., and Moore, T. C., Jr., 1975. Cenozoic history and paleoceanography of the central equatorial Pacific Ocean. Mem. Geol. Soc. Am., 14:1-134.

Weyl, R., 1980. Geology of Central America: Berlin (Gebruder BornTraeger).

Woodruff, F., 1979. Deep sea benthic foraminiferal changes associated with the middle Miocene oxygen isotopic event, DSDP Site 289, equatorial Pacific [Master's thesis]. University of Southern California, Los Angeles.

Woodruff, F., in press. Changes in Miocene deep-sea benthic foraminiferal distribution in the Pacific Ocean: relationship to paleoceanography. Geol. Soc. Am. Spec. Publ.

Woodruff, F., and Douglas, R. G., 1981. Response of deep sea benthic foraminifera to Miocene paleoclimatic events, DSDP Site 289. Mar. Micropaleontol., 6:617-632.

Wyrtki, K., 1966. Oceanography of the eastern equatorial Pacific Ocean. Oceanogr. Mar. Biol. Ann. Rev., 4:33-68.

\section{APPENDIX \\ Taxonomic Notes}

Alabamina polita Becker and Dusenbury, 1958, Cushman Found. Foram. Res. Spec. Publ., no. 4, p. 40, pl. 7, figs. 3 a-c. This paper, Pl. 6, Fig. 10.

Alveolophragmium crassimargo (Norman)-Haplophragmoides crassimargo Norman, 1892, Museum Normanianum, Pt. 7-8, p. 17. This paper, Pl. 1, Fig. 3. Ecology: inner shelf (Loeblich and Tappan, 1953).

Ammonia breccarii (Linné)-Nautilus beccarii Linné, 1758, Systemma naturae (Vol. 1, 10th Ed.), p. 710, pl. 1, figs. la-c. Ecology: inner shelf (Smith, 1964; Ingle, 1980).

Amphistegina lessonii d'Orbigny, 1826, Ann. Sci. Nat. Paris, Ser. 1, Vol. 7, p. 304, Modeles no. 98, 4me livraison. Ecology: inner shelf (Murray, 1973).

Anomalina alazaensis Nuttall, 1932, J. Paleontol., Vol. 6, p. 31, pl. 8, figs. 5-7.

Anomalina cicatricosus Schwager, 1966, Geol. Theil, Bd. 2, Abt. 2, p. 260 , pl. 7 , figs. 4,108 . 
Anomalina flintii Cushman, 1931, U.S. Nat. Mus. Bull., no. 104, p. 108 , pl. 18 , fig. 5 .

Anomalinoides globulosus (Chapman and Parr)-Anomalina globulosa Chapman and Parr, 1937, Australasioan Antarctic Exped., 1911-1914, Sci. Repts. Sydney, Australia, Ser. C (Zool., Botany), Vol. 1, p. 117, pl. 9, fig. 27. Ecology: upper middle bathyal (Anomalina globulosa of Pflum and Frerichs, 1976).

Anomalinoides pompilioides (Galloway and Heminway)-Anomalina pompilioides Galloway and Heminway, 1941, N.Y. Acad. Sci., Sci. Survey Puerto Rico and Virgin Islands, Vol. 3, p. 389, pl. 22, fig. 3.

Anomalinoides semicribratus (Beckman)-Anomalina pompilioides Galloway and Heminway semicribrata Beckman, 1953, Eclogae Geol. Helv., Vol. 10, pp. 400-401. pl. 27, fig. 3, text-figs. 24-25.

Astigerina guraboensis Bermudez, 1949, Cushman Lab. Foram. Res. Spec. Publ., no. 25, pp. 265-266. pl. 19, figs. 34-36.

Astrononion guadalupae (Parker)-Melonis guadalupae Parker, 1964, J. Paleontol., Vol. 38, p. 633, pl. 100, figs. 13-14.

Baggina dominicana Bermudez, 1949, Cushman Lab. Foram. Res. Spec. Publ., no. 25 , p. 260 , pl. 18 , figs. $37-39$.

Boldia cushmani (Nuttall)—Cibicides cushmani Nuttall, 1930, J. Paleontol., Vol. 4, p. 291, pl. 25, figs. 3, 5, 6.

Bolivina acuminata Natland-Bolivina subadvena var. acuminata Natland, 1946, in Cushman, J. A., and Gray, H. B., Cushman Lab. Foram. Res. Spec. Publ., no. 19, p. 34, pl. 5, fig. 46. Ecology: outer shelf (Smith, 1964).

Bolivina advena Cushman, 1925, Contr. Cushman Lab. Foram. Res., Vol. 1, p. 29, pl. 5, figs. la-b. Ecology: upper bathyal (Ingle, 1980).

Bolivina advena striatella Cushman-Bolivina advena Cushman striatella Cushman, 1925, Contr. Cushman Lab. Foram. Res., Vol. 1, p. 30, pl. 5, fig. 3. Ecology: upper bathyal (Ingle, 1980).

Bolivina alazaensis Cushman, 1926, Contr. Cushman Lab. Foram. Res., Vol. 1, p. 82, pl. 12, fig. 1.

Bolivina alta (Sequenza)-Valvulina alata Sequenza, 1862, Att. Acad. Gioenia. Sci. Nat., Ser. 22, Vol. 18, p. 115. pl. 2, fig. 5.

Bolivina argentea Cushman, 1926, Contr. Cushman Lab. Foram. Res., Vol. 2, pl. 6, fig. 5. Ecology: upper middle bathyal (Smith, 1964).

Bolivina beyrichi Reuss, 1851, Z. Deut. Geol. Ges. (Berlin), Bd. 3, p. 83 , pl. 6 , fig. 51 . This paper, Pl. 3, Fig. 3. Ecology: outer shelf (Smith, 1964). Smith (1964) synonomizes this species with Bolivina brady, which ranges from 80 to $450 \mathrm{~m}$ (outer shelf to upper bathyal).

Bolivina bicostata Cushman-Bolivina costata d'Orbigny bicostata Cushman, 1926, Contr. Cushman Lab. Foram. Res., Vol. 2, p. 42. This paper, Pl. 3, Fig. 4. Ecology: outer shelf (Smith, 1964).

Bolivina bradyi Asano, 1938, J. Geol. Soc. Japan, Vol. 45, no. 538, p. 603 , pl. 16, fig. 2. This paper, Pl. 3, Fig. 6. Ecology: outer shelf (Smith, 1964).

Bolivina bramletti Kleinpell, 1938, Miocene Stratigraphy of California: Tulsa, Oklahoma (Am. Assoc. Pet. Geol.), p. 267, pl. 21, figs. 9-11. Ecology: upper bathyal (Ingle, 1980).

Bolivina californica Cushman, 1925, Contr. Cushman Lab. Foram. Res., Vol. 1, p. 32, pl. 15, fig. 10.

Bolivina conica Cushman, 1925, Contr. Cushman Lab. Foram. Res., Vol. 1, p. 30, pl. 5, fig. 4. Ecology: upper middle bathyal (Ingle, 1980).

Bolivina decussata Brady, 1881, Q., J. Microsc. Sci., (London), n. s., Vol. 21, p. 58. Ecology: outer shelf (Smith, 1973).

Bolivina floridana Cushman, 1918, U.S. Geol. Surv. Bull., no. 676, p. 49 , pl. 10, fig. 4. Ecology: upper middle bathyal (Ingle, 1980).

Bolivina foraminata Stewart and Stewart-Bolivina seminuda Cushman foraminata Stewart and Stewart, J. Paleontol., Vol. 4, p. 66, pl. 8, fig. 5. This paper, Pl. 3, Fig. 7. Ecology: upper bathyal (Resig, 1981).

Bolivina gasparensis Bermudez, 1949, Cushman Lab. Foram. Res. Spec. Publ., no. 25, p. 190, pl. 12, figs. 33-34.

Bolivina globulosa Cushman, 1933, Contr. Cushman Lab. Foram. Res., Vol. 9 , p. 80 , pl. 8 , fig. 9.

Bolivina granti Rankin, 1934-Cushman and Kleinpell, 1934, Contr. Cushman Lab. Foram. Res., Vol. 10, p. 21, pl. 4, figs. 2-3. Ecology: upper middle bathyal (ingle, 1980).

Bolivina interjuncta Cushman-Bolivina costata d'Orbigny interjuncta Cushman, 1926, Contr. Cushman Lab. Foram. Res., Vol. 2, p. 41, pl. 6, fig. 3. Ecology: upper bathyal-shallow oxygen-minimum zone (Ingle, 1980; Ingle and Keller, 1980).
Bolivina marginata Cushman, 1925, U.S. Geol. Surv. Bull., no. 676, p. 48 , pl. 10, fig. 1. Ecology: upper bathyal (Ingle, 1980).

Bolivina obscuranta Cushman, 1936, Cushman Lab. Foram. Res. Spec. Publ., no. 6, p. 53, pl. 7, fig. 20.

Bolivina pacifica Cushman and McCulloch-Bolivina acerosa Cushman pacifica Cushman and McCulloch, 1942, Allan Hancock Pacific Exped. Repts., (Vol. 6): Los Angeles (University Southern California), p. 185, pl. 21 figs. 2-3. Ecology: upper bathyal-shallow oxygen-minimum zone (Smith, 1964; Ingle, 1980; Ingle and Keller, 1980).

Bolivina plicata d'Orbigny, 1839, Voyage dans l'Amerique Meridionale: Foraminiferes (Vol. 5): Strasbourg, France (Levrault). Pt. 5 , p. 62 , pl. 8 , figs. $4-7$.

Bolivina plicata d'Orbigny of Resig, 1981, Mem. Geol. Soc. Am., 154 , p. 646 , pl. 1, figs. 3-4. This paper, Pl. 3, Fig. 8. Ecology: upper bathyal (Resig, 1981).

Bolivina pseudobeyrichi Cushman, 1911, Contr. Cushman Lab. Foram. Res., Vol. 2, p. 45. This paper, Pl. 3, Fig. 9. Ecology: upper bathyal (Smith, 1964; Ingle, 1980).

Bolivina pseudospissa Kleinpell, 1938, Miocene Stratigraphy of California: Tulsa, Oklahoma (Am. Assoc. Pet. Geol.), p. 279, pl. 21, fig. 6. Ecology: upper middle bathyal (Ingle, 1980).

Bolivina scabrata Cushman and Bermudez, 1936, Contr. Cushman Lab. Foram. Res., Vol. 12, p. 29, pl. 5, figs. 11-12.

Bolivina seminuda Cushman, 1911, U.S. Nat. Mus. Bull., no. 71, p. 34, tf. 55. Ecology: upper bathyal (Smith, 1964).

Bolivina semiperforata Martin, 1952, Contr. Cushman Found. Foram. Res., Vol. 3, p. 129, pl. 21, figs. 10-11. This paper Pl. 3, Fig. 10. Ecology: upper middle bathyal (Smith, 1964; Ingle, 1980).

Bolivina sinuata Galloway and Wissler, 1927, J. Paleontol., Vol. 1, p. 71, pl. 11, fig. 9. Comments: Specimens assigned to this species have four ridges, which are formed by the retral processes and by numerous discontinuous costae. Mega- and microspheric forms are recognized in the Middle America Trench Leg 84 samples. Ecology: upper middle bathyal (Ingle, 1980).

Bolivina cf. B. sinuata Galloway and Wissler. Comments: Specimens included in this species group have a single central ridge rather than four ridges as in Bolivina sinuata Galloway and Wissler. Both mega- and microspheric forms have been found in the Middle America Trench Leg 84 samples.

Bolivina spissa Cushman, 1926-Bolivina subadvena Cushman spissa Cushman, 1926, Contr. Cushman Lab. Foram. Res., Vol. 2, p. 29, p. 45 , pl. 6, fig. 8. Ecology: upper middle bathyal (Ingle and Keller, 1980).

Bolivina striatula Cushman, 1922, Carnegie Inst. Washington Publ. no. 311 , p. 27, pl. 3, fig. 10. Ecology: inner shelf (Smith, 1964).

Bolivina subadvena Cushman 1926, Contr. Cushman Lab. Foram. Res., Vol. 2, p. 44, pl. 6, fig. 6. Ecology: outer shelf (Smith, 1964).

Bolivina subadvena sulpherensi shman-Bolivina subadvena Cushman sulpherensis Cushman, -, Contr. Cushman Lab. Foram, Res., Vol. 11, p. 20, pl. 3, fig Ecology: upper middle bathyal (Ingle, 1980).

Bolivina tectiformis Cushman, 192, Contr. Cushman Lab. Foram. Res., Vol. 1, p. 83 , pl. 12, fig. 6.

Bolivina tongi filacostata Cushman and McCulloch-Bolivir a tongi Cushman filacostata Cushman abd McCulloch, 1942, Allan Hancock Pacific Exped. Repts. (Vol. 6): Los Angeles (Univ. So. Calif.), p. 214, pl. 27, figs. 7-11. Ecology: inner shelf (Smith, 1964).

Bolivina woodringi Kleinpell, 1938, Miocene Stratigraphy of California: Tulsa, Oklahoma (Am. Assoc. Pet. Geol.), p. 285, pl. 21, figs. 4-5. Ecology: upper middle bathyal (Ingle, 1980).

Bolivinita quadrilatera (Schwager)-Textilaria quadrilatera Schwager, 1866, Novara Exped. 1857-1859, Geol. Theil, Bd. 2, Abt. 2, p. 253, pl. 7, fig. 103.

Buccella sp. Ecology: inner shelf (Murray, 1973).

Bulimina alazaensis Cushman, 1927, J. Paleontol., Vol. 1, p. 161, pl. 25, fig. 4. This paper, Pl. 3, Fig. 14. Ecology: lower middle bathyal. Bulimina alazaensis is morphologically similar to $B$. Corrugata and $B$. rostrata, which are assigned upper depth limits within the lower middle bathyal biofacies (Ingle, 1980; Ingle and Keller, 1980).

Bulimina bleekeri Hedberg, 1937, J. Paleontol., Vol. 11, p. 675, pl. 91, figs. 12-13.

Bulimina denudata Cushman and Parker-Bulimina pagoda Cushman denudata Cushman and Parker, 1938, Contr. Cushman Lab. 
Foram. Res., Vol. 14, p. 57, pl. 10, figs. 1-2. This paper, Pl. 3, Fig. 13. Ecology: outer shelf (Smith, 1964; Ingle, 1980).

Bulimina jarvisi Cushman and Parker, 1936, Contr. Cushman Lab. Foram. Res., Vol. 12, p. 39, pl. 7, fig. 1.

Bulimina mexicana Cushman-Bulimina inflata Sequenza var. mexicana Cushman, 1922, U.S. Nat. Mus. Bull., no. 104, p. 95, pl. 21 , fig. 2. This paper, Pl. 3, Fig. 14. Ecology: upper middle bathyal (Ingle and Keller, 1980). Smith (1964) finds that this species occurs no shallower than the lower middle bathyal biofacies off Central America; in this study however, the upper middle bathyal limit will be used.

Bulimina pagoda Cushman, 1927, Scripps Inst. Oceanogr. Tech. Ser., Vol. 1, p. 152, pl. 2, fig. 16.

Bulimina rostrata Brady, 1884, Rept. Challenger Exped. (Zool.), Vol. 9, Pt. 22, p. 408, pl. 51, figs. 14-15. Ecology: lower middle bathyal (Ingle, 1980; Ingle and Keller, 1980).

Bulimina subaccuminata Cushman and Stewart, 1930, in Cushman, Stewart, and Stewart, San Diego Soc. Nat. Hist. Trans., Vol. 6, p. 65, pl. 5, figs. 2, 3a-b. Ecology: lower middle bathyal (Resig, 1981).

Bulimina uvigerinaformis Cushman and Kleinpell, 1934, Contr. Cushman Lab. Foram. Res., Vol. 10, p. 5, pl. 1, fig. 14. Ecology: lower middle bathyal (Ingle, 1980).

Buliminella curta Cushman, 1925, Contr. Cushman Lab. Foram. Res., Vol. 1, p. 33, pl. 5, fig. 13. This paper, Pl. 2, Fig. 11. Ecology: outer shelf (Ingle, 1980).

Buliminella curta basispinata Stewart and Stewart-Buliminella curta Cushman basispinata Stewart and Stewart, 1930, J. Paleontol., Vol. 4 , p. 63 , pl. 8 , figs. 6 .

Buliminella subfusiformis Cushman, 1925, Contr. Cushman Lab. Foram. Res., Vol. 1, p. 33, pl. 5, fig. 12. This paper, Pl. 3, Fig. 1. Ecology: upper bathyal (Ingle, 1980).

Buliminella tenuata Cushman-Buliminella subfusiformis Cushman tenuata Cushman, 1927, Scripps Inst. Oceanogr. Tech. Ser., Vol. 1, p. 149, pl. 2, fig. 9. Ecology: upper bathyal, shallow oxygenminimum zone (Ingle and Keller, 1980).

Cancris auricula (Fitchel and Moll)-Nautilus auricula Fitchel and Moll var. $\alpha$ and var. $\beta$ Fitchel and Moll, 1798, Microsopische und andere kleine Schalthiere aus den Geschlechtern Argonaute und Schiffer, p. 108. Ecology: inner shelf (Ingle, 1980).

Cancris carmenesis Natland, 1950, Mem. Geol. Soc. Am., no. 43, p. 32, pl. 9, fig. 1. Ecology: upper bathyal (Resig, 1981). Smith (1964) finds this species occurring at upper middle bathyal depths off Central America.

Cancris inflatus (d'Orbigny) - Valvulina inflata d'Orbigny, 1839, Voyage dans l'Amerique Meridionale: Foraminiferes (Vol. 5): Strasbourg, France (Levrault), Pt. 5, p. 48, pl. 7, figs. 7-9. This paper, Pl. 5, Fig. 3. Ecology: upper bathyal (Smith, 1964).

Cancris oblonga (d'Orbigny) - Valvulina oblonga d'Orbigny, 1839, in Barker-Webb, P., and Berthelot, S. (Eds.), Histoire Naturelle des l'iles Canaries (Vol. 2, Foraminifères): Paris (Bethune), p. 136, pl. 1, figs. 40-42. Ecology: upper middle bathyal (Smith, 1964).

Cancris panamensis Natland, 1938, Scripps Inst. Oceanogr. Bull. Tech. Ser., Vol. 4, p. 148, pl. 6, fig. 1. Ecology: outer shelf (Smith, 1964).

Cancris sagra (d'Orbigny)-Rotalina (Rotalina) sagra d'Orbigny, 1839, "Foraminifères," in de la Sagra, R. (Ed.), 1839, Histoire physique et naturelle de l'ile de Cuba (Vol. 8): Paris (Bertrand), p. 77, pl. 5, figs. 13-15. This paper, Pl. 5, Fig. 2. Ecology: inner shelf (Smith, 1964).

Cassidulina californica Cushman and Hughes, 1925, Contr. Cushman Lab. Foram. Res., Vol. 1, p. 12, pl. 2, fig. 1. This paper, Pl. 6, Fig. 4. Ecology: upper bathyal (Ingle, 1964).

Cassidulina caudriae Cushman and Stainforth, 1945, Cushman Lab. Foram. Res. Spec. Publ., no. 14, p. 64, pl. 12, figs. 2-3.

Cassidulina crassa d'Orbigny, 1839, Voyage dans l'Amerique Meridionale: Foraminiferes (Vol. 5): Strasbourg, France (Levrault), Pt. 5, p. 56, pl. 7, figs. 18-20. Ecology: upper middle bathyal (Smith, 1964; Ingle and Keller, 1980). Smith (1964) does note rare occurrence of this species as shallow as $435 \mathrm{~m}$ (upper bathyal) off Central America.

Cassidulina cushmani Stewart and Stewart, 1930, J. Paleontol., Vol. 4, p. 71, pl. 9, fig. 5. Ecology: upper middle bathyal (Smith, 1964; Ingle and Keller, 1980).
Cassidulina delicata Cushman, 1927, Scripps Inst. Oceanogr. Tech Ser., Vol. 1, p. 168, pl. 6, fig. 5. Ecology: upper middle bathyal (Ingle, 1980).

Cassidulina depressa Asano and Nakamura-Cassidulina subglobosa Brady depressa Asano and Nakamura, 1937, Japan. J. Geol., Geogr., Vol. 14, p. 148, pl. 13, fig. 8.

Cassidulina laevigata d'Orbigny, 1826, Ann. Sci. Nat., Ser. 1, Vol. 7, p. 282 , pl. 15 , figs. $4-5,5$ bis. This paper, Pl. 6, Fig. 7. Ecology: upper bathyal to upper middle bathyal (Smith, 1964; Ingle, 1980). Outer shelf forms with an acute periphery but no carinae were included in this species by Smith (1964) and considered an ecologic variation. Only forms with carinae were recognized in the Leg 84 samples, so the upper bathyal biofacies was used as the upper depth limit for this species.

Cassidulina laevigata carinata Silvestri- Cassidulina laevigata d'Orbigny carinata Silvestri, 1896, Accad. Pont. Nuovi Lincei (Italy), Vol. 12, p. 104, pl. 2, figs. 10a-c. Comments: Only forms with a distinct keel described as thin carinae by Cushman (1922) are included in this species. This variation is probably an ecologic variation of $C$. laevigata d'Orbigny, since the trend recognized by Smith (1964) indicates that the periphery becomes more acute and develops a keel as depth increase off Central America. Ecology: upper middle bathyal (Ingle, 1980).

Cassidulina limbata Cushman and Hughes, 1925, Contr. Cushman Lab. Foram. Res., Vol. 1, p. 12, pl. 2. fig. 2. This paper, Pl. 6, Fig. 5. Ecology: upper bathyal (Ingle, 1980).

Cassidulina minuta Cushman, 1933, Contr. Cushman Lab. Foram. Res., Vol. 9, p. 92, pl. 10, fig. 3. Ecology: outer shelf (Smith, 1964).

Cassidulina oblonga Reuss, 1850, K. Akad. Wiss. Wien, Math-Na. Cl, Denkschr., Vol. 1, p. 376, pl. 48, figs. 5-6. Ecology: outer shelf (Smith, 1964; Ingle, 1980).

Cassidulina quadrata Cushman and Hughes-Cassidulina subglobosa Brady quadrata Cushman and Hughes, 1925, Contr. Cushman Lab. Foram. Res., Vol. 1. p. 15, pl. 2, fig. 7.

Cassidulina reflexa Galloway and Wissler, 1927, J. Paleontol., Vol. 1, p. 80 , pl. 12 , fig. 13 .

Cassidulina spinifera Cushman and Jarvis, 1929, Contr. Cushman Lab. Foram. Res., Vol. 5, p. 17, pl. 3, fig. 1.

Cassidulina tortuosa Cushman and Hughes, 1925, Contr. Cushman Lab. Foram. Res., Vol. 1, p. 14, pl. 2, fig. 4.

Cassidulina tricamerata Galloway and Heminway, 1941, N.Y. Acad. Sci., Sci. Survey Puerto Rico and Virgin Islands, Vol. 3, p. 425, pl. 32 , fig. 3.

Cassidulina tumida Natland, 1938, Scripps Inst. Oceanogr. Bull. Tech. Ser., Vol. 4, p. 148, pl. 6, figs. 2-3. Ecology: upper middle bathyal (Smith, 1964). Smith (1964) also noted that the forms with broadly rounded peripheries were present from 435 to $450 \mathrm{~m}$, and that the forms with serrated keels had an upper depth limit of 800-885 m off Central America. Similar morphologic variations were noted in the Leg 84 samples, and the two forms are indicated on the fossil lists as C. tumida and C. tumida (keel)

Cassidulinella renulinaformis Natland, 1940, J. Paleontol., Vol. 14, p. 571 , pl. 69 , figs. $1-4$.

Cassidulinoides bradyi (Norman)-Cassidulina bradyi Norman, 1881 , Q. J. Microsc. Sci. (London), n. s., Vol. 21, p. 59. This paper, Pl. 3, Fig. 12.

Cassidulinoides tenuis Phleger and Parker, 1951, Mem. Geol. Soc. $A m$., no. 46 , p. 27 , pl. 4 , figs. 14-17. Ecology: upper middle bathyal (Smith, 1964).

Cassidulinoides waltoni Uchio, 1960, Cushman Found. Foram. Res. Spec. Publ., no. 5, p. 69, pl. 9, figs. 24-27.

Ceratobulimina alazaensis Cushman and Harris, 1927, Contr. Cushman Lab. Foram. Res., Vol. 3, p. 174, pl. 29, fig. 5, pl. 30, figs. 3-5.

Chilostomella fimbrata Cushman, 1926, Contr. Cushman Lab. Foram. Res., Vol. 1, p. 78 , pl. 11, figs. 22a-c.

Chilostomella globata Galloway and Heminway, 1941, N.Y. Acad. Sci., Sci. Survey Puerto Rico and Virgin Islands, Vol. 3, p. 409, pl. 28, fig. 2 .

Chilostomella oolina Schwager, 1878, Uff. Geol. (R. Com. Geol. Ital.) Boll. (Italy), Vol. 9, p. 527, pl. 1, fig. 16.

Chilostomella ovoidea Reuss, 1850, K. Akad. Wiss. Wien, Math.-Naturwiss. Kl., Denkschr., Vol. 1, p. 380, pl. 48, fig. 12. Ecology: upper middle bathyal-shallow oxygen-minimum zone (Ingle, 1980). 
Uchio (1960) reports this species living at depths as shallow as 61 fathoms $(+112 \mathrm{~m}$, outer shelf) in the California borderland. Ingle's upper depth limit and oxygen-minimum association thus represent the most probable depth at which this species would be preserved, and not an upper depth limit. Similar problems have been noted with thin-walled or delicate species such as Suggrundia, which tend to be associated with low-oxygen conditions (Douglas and Heitman, 1979).

Chrysalogonium breviloculum Cushman and Jarvis, 1934, Contr. Cushman Lab. Foram. Res., Vol. 10, p. 74, pl. 10, fig. 13.

Chrysalogonium elongatum Cushman and Jarvis, 1934, Contr. Cushman Lab. Foram. Res., Vol. 10, p. 73, pl. 10, figs. 10-11.

Chrysalogonium lanceolum Cushman and Jarvis, 1934, Contr. Cushman Lab. Foram. Res., Vol. 10, p. 75, pl. 10, fig. 16.

Chrysalogonium longiscatatum Cushman and Jarvis, 1934, Contr. Cushman Lab. Foram. Res., Vol. 10, p. 74, pl. 10, fig. 12.

Chrysalogonium teniucostatum Cushman and Bermudez, 1936, Contr. Cushman Lab. Foram. Res., Vol. 12, p. 27, pl. 5, figs. 3-5.

Cibicides barnetti Bermudez, 1949, Cushman Lab. Foram. Res. Spec. Publ., p. 295, pl. 24, figs. 7-9.

Cibicides dohmi Bermudez, 1949, Cushman Lab. Foram. Res. Spec. Publ., no. 25, p. 297 , pl. 24 , figs. $25-27$.

Cibicides fletcheri Galloway and Wissler, 1927, J. Paleontol., Vol. 1, p. 64, pl. 10. figs 8-9. Comments: Specimens included in this species were restricted to forms with a flat spiral side and a convex umbilical side. Ecology: inner shelf (Ingle, 1980).

Cibicides cf. C. fletcheri Galloway and Wissler. Comments: This group includes forms which deviated from the restrictions already noted (C. fletcheri). The primary variation was a concave spiral side, which could indicate that the specimens were attached and that the shape was altered by the surface of attachment.

Cibicides floridanus (Cushman)-Truncatulina floridana Cushman, 1918, U.S. Geol. Surv. Bull., no. 676, p. 62, pl. 19, fig. 2. Comments: Specimens included in this species are unequally biconvex, and have thickened calcite deposits on the spiral side and sutures which are limbate and slightly raised. These specimens may be confused with C. yaquatensis Bermudez; $C$. floridanus is, however, larger and more equally biconvex. Ecology: lower middle bathyal (Ingle, 1980). Smith (1964) finds specimens of $C$. floridanus in the outer-shelf biofacies. Her specimens are not $C$. floridanus as used in this study.

Cibicides cf. C. floridanus (Cushman). Comments: A few specimens were observed at Site $570(570-26-1,14-16 \mathrm{~cm}$ and 570-30-1, 10-14 $\mathrm{cm}$ ) which have thicker calcite umbos than typical. These specimens were separated from the typical forms, because of the probable ecologic significance of this character.

Cibicides gramulosa Bermudez, 1949, Cushman Lab. Foram. Res. Spec. Publ. no. 25, p. 298 , pl. 24 , figs. $10-12$.

Cibicides guraboensis Bermudez, 1949, Cushman Lab. Foram. Res. Spec. Publ., no. 25, p. 299, pl. 26, figs. 31-33.

Cibicides hunteri Bermudez, 1949, Cushman Lab. Foram. Res. Spec. Publ., no. 25. p. 300 , pl. 24 , figs. $31-33$.

Cibicides heminwayae Bermudez, 1949, Cushman Lab. Foram. Res. Spec. Publ., no. 25, p. 299, pl. 24, figs. 1-3.

Cibicides io Cushman-Cibicides pseudoungeriana (Cushman) io Cushman, 1931, U.S. Nat. Mus. Bull., no. 104, p. 125, pl. 23, figs. 1-2.

Cibicides matanzaensis (Hadley) - Planulina matanzaensis Hadley, 1934, Bull. Am. Paleontol., Vol. 20, no. 70A, p. 27, pl. 4, figs. 1-3.

Cibicides mckannai Galloway and Wissler, 1927, J. Paleontol., Vol. 1, p. 65 , pl. 10, figs. 5-6.

Cibicides mexicanus Nuttall, 1932, J. Paleontol., Vol. 6, p. 33, pl. 9, figs. 7-9.

Cibicides nucleatus (Sequenza)-Truncatulina nucleata Sequenza, 1880, Mem. R. Accad. Lincei, Cl. Sci. Fis., Mat., Nat., Ser. 3, Vol. 6, p. 64 , pl. 7 , fig. 8 .

Cibicides pseudoungerianus (Cushman)-Truncatulina pseudoungeriana Cushman, 1922, U.S. Geol. Surv. Prof. Pap., 129-E, p. 97, pl. 20 , fig. 9.

Cibicides richarsoni Bermudez, 1949, Cushman Lab. Foram. Res. Spec. Publ., no. 25, p. 305, pl. 26, figs. 22-24.

Cibicides spiralis Natland, 1938, Scripps Inst. Oceanogr. Bull. Tech. Ser., Vol. 4, p. 151, pl. 7, fig. 7. This paper, Pl. 5, Fig. 9. Ecology: upper middle bathyal (Ingle, 1980; Ingle and Keller, 1980).
Cibicides spirolimbatus Galloway and Heminway, 1941, N.Y. Acad. Sci., Sci. Survey Puerto Rico and Virgin Islands, Vol. 3, p. 397, pl. 25 , fig. 1 .

Cibicides trincherasensis Bermudez, 1949, Cushman Lab. Foram. Res. Spec. Publ., no. 25, p. 307, pl. 25, figs. 1-3.

Cibicides umbonatus Phleger and Parker, 1951, Mem. Geol. Soc. Am., no. 46 , p. 31 , pl. 17, figs. 7-8, 9a-b. Ecology: outer shelf to upper bathyal (Pflum and Frerichs, 1976).

Cibicides yaqatensis Bermudez, 1949, Cushman Lab. Foram. Res. Spec. Publ., no. 25, p. 308, pl. 26, figs. 16-18. This paper, Pl. 5, Fig. 11.

Cibicidoides bradyi (Trauth)-Truncatulina bradyi Trauth, 1918, K. Akad. Wiss. Wien, Math.-Naturwiss. Kl., Denkschr., Vol. 95, p. 235. Ecology: upper middle bathyal (Ingle and Keller, 1980).

Cibicidoides coryelli (Bermudez)-Cibicides coryelli Bermudez, 1949, Cushman Lab. Foram. Res. Spec. Publ., no. 25, pl. 25, figs. 7-9.

Cibicidoides grimsdalei (Nuttall)-Cibicides grimsdalei Nuttall, 1930, J. Paleontol., Vol. 4, p. 291, pl. 25, figs. 7-8, 11.

Cibicidoides kullenbergi (Parker)-Cibicides kullenbergi Parker, 1953, Swedish Deep-Sea Exped., 1947-1948, Repts., Vol. 7, p. 49, pl. 11, figs. 7-8. Ecology: lower middle bathyal (Pflum and Frerichs, 1976; Ingle and Keller, 1980). Woodruff and Douglas (1981) note that $C$. kullenbergi (Parker) was rare at depths greater than $2.5 \mathrm{~km}$ (lower bathyal) before $16 \mathrm{Ma}$ ago and that after $12 \mathrm{Ma}$ ago it was associated with warm waters in the Miocene and Quaternary.

Cibicidoides mundulus (Brady, Parker and Jones)-Truncatulina mundulus Brady, Parker and Jones, 1888, Trans. Zool. Soc. London, Vol. 12 , p. 228 , pl. 45 , figs. 25 a-c.

Cibicidoides sinstralis (Coryell and Rivero)-Cibicidoides sinistralis Coryell and Rivero, 1940, J. Paleontol., Vol. 14, p. 335, p. 44, figs. $12 \mathrm{a}-\mathrm{c}$.

Cibicidoides cf. C. sinistralis (Coryell and Rivero). Comments: Specimens assigned to this group have a poorly developed keel and are not sinistrally coiled.

Cibicidoides trinitatensis (Nuttall) - Truncatulina trinitatensis Nuttall, 1928, Geol. Soc. Q. J. (London) Vol. 84, pl. 7, figs. 3, 5-6.

Cibicidoides wuellerstorfi (Schwager)-Anomalina wuellerstorfi Schwager, 1866, Novara Exped., 1857-1859, Geol. Theil, Bd. 2, Abt. 2, p. 258 , pl. 7, figs. 105, 107. Ecology: upper middle bathyal, depths greater than $3000 \mathrm{ft} .( \pm 1000 \mathrm{~m})$ (Pflum and Frerichs, 1976).

Cyclammina cancellata Brady, 1879, Q. J. Microsc. Sci., n.s. Vol. 19, p. 62 .

Cyclogyra foliacea (Philippi)-Orbis foliaceus Philippi, 1844, Enumeratio molluscorum Siciliae cum viventum tum in tellure Tertiaria fossilium quae in itinere euo observavit: Halle, Saxony, Germany (E. Anton), Vol. 2, p. 147, pl. 24, fig. 26.

Dentalina baggi Galloway and Wissler, 1927, J. Paleontol., Vol. 1, p. 49 , pl. 8 , figs. $14-15$.

Dentalina cocoaensis (Cushman)-Nodosaria cocoaensis Cushman, 1925, Contr. Cushman Lab. Foram. Res., Vol. 1, p. 66, pl. 10, figs. 5-6.

Dentalina consobrina d'Orbigny, 1846, Die Fossilen Foraminiferen des Tertiaeren Beckens von Wien: (Gide et Comp.), p. 46, pl. 2, figs. $1-3$.

Dentalina cooperensis Cushman, 1933, Contr. Cushman Lab. Foram. Res., Vol. 9, p. 8, pl. 1, fig. 17.

Dentalina ittai Loeblich and Tappan, 1953, Smithsonian Inst. Misc. Coll., Vol. 121, p. 56, pl. 10, figs. 10-12.

Dentalina nucronata Neugeboren, $1856, \mathrm{~K}$. Akad. Wiss., Math.-Naturwiss. Kl., Denkschr., Bd. 12, Abt. 2, p. 83, pl. 3, figs. 8-11.

Dentalina paupertata d'Orbigny, 1846, Die Fossilen Foraminiferen des Tertiaeren Beckens von Wien: (Gide et Comp.), p. 46, pl. 1. figs. 57-58.

Dentalina soluta Reuss, 1851, Z. Deut. Geol. Ges., Bd. 3, p. 60, pl. 3, figs. $4 a-b$.

Dentalina spinosa d'Orbigny, 1846, Die Fossilen Foraminiferen des Tertiaeren Beckens von Wien: (Gide et Comp.), p. 55, pl. 2, figs. 36-37.

Dentostomina guraboensis Bermudez, 1949, Cushman Lab. Foram. Res. Spec. Publ., no. 25, p. 104, pl. 6, fig. 2.

Dyocibicides perforata Cushman and Valentine, 1930, Stanford Univ. Dept. Geol. Contr., Vol. 1, p. 31, pl. 10, fig. 3. Ecology: inner shelf (Cushman and Valentine, 1930). 
Eggerella bradyi (Cushman)-Verneuillina bradyi Cushman, 1911, U.S. Nat. Mus. Bull., no. 71 , p. 54, tf. 87. Ecology: lower middle bathyal (Ingle and Keller, 1980).

Eggerella pusilla (Goes)-Verneuillina pusilla Goes, 1896, Harvard College Mus. Comp. Zool. Bull., Vol. 29, p. 39, pl. 5, figs. 6-8. Comments: This species is longer and less flaring than $E$. bradyi. Ecology: lower middle bathyal (Goes, 1896). Type species is from $1990 \mathrm{~m}$ in the Pacific off Mexico. No additional information on the occurrence has been found.

Ehrenbergina. Species of this genus are most common at depths of 2.3 to $4.2 \mathrm{~km}$ in the Atlantic (Lohmann, 1978). This depth association has been adopted for all species of Ehrenbergina in this study. Examples of depth associations in the Pacific Ocean are given under the species. Deviations from the lower bathyal to abyssal association are stressed.

Ehrenbergina amina Bermudez, 1949, Cushman Lab. Foram. Res. Spec. Publ., no. 25, p. 270, pl. 20, figs. 44-46.

Ehrenbergina bosoensis Takayanagi, 1951, Paleontol. Soc. Japan Trans. Proc., n.s., no. 3 , p. $87-88$, tf. 8 .

Ehrenbergina bradyii Cushman, 1922. U.S. Nat. Mus. Bull., no. 104, p. 134 , pl. 26, fig. 5. This paper, Pl. 6, Fig. 8.

Ehrenbergina caribbea Galloway and Heminway, 1941, N.Y. Acad. Sci., Sci. Survey Puerto Rico and Virgin Islands, Vol. 3, p. 426, pl. 32 , fig. 4

Ehrenbergina compressa Cushman, 1927, Scripps Inst. Oceanogr. Tech. Ser., Vol. 1, p. 168, pl. 6, fig. 7. This paper, Pl. 6, Fig. 9. Ecology: upper bathyal (Ingle, 1980).

Ehrenbergina hystrix Brady, 1881, Q. J. Microsc. Sci. London, n.s., Vol. 21, p. 60.

Ellipsoglandulina multicostata (Galloway and Morrey)—Daucina multicostata Galloway and Morrey, 1929, Bull Am. Paleontol., Vol. 15, p. 42 , pl. 6 , fig. 13 .

Ellipsolagena barri Cushman and Stainforth, 1945, Cushman Lab. Foram. Res. Spec. Publ., no. 14, p. 59, pl. 10, fig. 14.

Ellipsonodosaria decurta Bermudez, 1949, Cushman Lab. Foram. Res. Spec. Publ., no. 25, p. 56, pl. 10, fig. 1.

Ellipsonodosaria mappa Cushman and Jarvis, 1934, Contr. Cushman Lab. Foram. Res., Vol. 10, p. 73, pl. 10, fig. 8.

Elphidium sagra (d'Orbigny)-Polystomella sagra d'Orbigny, 1839, in de la Sagra, R. (Ed.), Histoire physique et naturelle de l'ile de $\mathrm{Cu}$ $b a$ (Vol. 8): Paris (Bertrand), p. 55, pl. 6, figs. 19-20. Ecology: inner shelf (Murray, 1973).

Elphidium tumidum Natland, 1938, Scripps Inst. Oceanogr. Tech. Ser. Vol. 3, no. 10, chart, line 5. Ecology: inner shelf (Smith, 1964)

Epistominella bradyana (Cushman)-Pulvinulinella bradyana Cushman, 1927, Scripps Inst. Oceanogr. Tech. Ser., Vol. 1, p. 165, pl. 5, figs. 11-13. Ecology: outer shelf (Smith, 1964).

Epistominella cf. E. bradyana (Cushman). Comments: Specimens assigned to this group have a lobate periphery, more robust test and the sutures on the spiral side are more loosely curved.

Epistominella exigua (Brady)-Pulvinulinella exigua Brady, 1884, Rept. Challenger Exped. (Zool.), Vol. 9, Pt. 22, p. 696, pl. 103, figs. 13-14.

Epistominella obesa Bandy and Arnal, 1957, Contr. Cushman Lab. Foram. Res., Vol. 8, p. 56, pl. 7, fig. 8. Ecology: upper middle bathyal (Smith, 1964).

Epistominella pacifica (Cushman)-Pulvinulinella pacifica Cushman, 1927, Scripps Inst. Oceanogr. Tech. Ser., Vol. 1, p. 165, pl. 5, figs. 14-15. Ecology: upper middle bathyal (Ingle, 1980; Ingle and Keller, 1980).

Epistominella smithi (Stewart and Stewart)-Pulvinulinella smithi Stewart and Stewart, 1930, J. Paleontol., Vol. 4, p. 70, pl. 9, fig. 4. This paper, Pl. 4, Fig. 12. Ecology: upper middle bathyal (Smith, 1964). Off Central America, this species is associated with temperatures of $3-5^{\circ} \mathrm{C}$ and salinities of $34.56-34.61 \% 0$ (Smith, 1964).

Epistominella sp. of Resig, 1981, Mem. Geol. Soc. Am., no. 154, pl. 3 , figs. 3,6 .

Epistominella subperuviana (Cushman)_Pulvinulinella subperuviana Cushman, 1926, Contr. Cushman Lab. Foram. Res., Vol. 2, p. 63 , pl. 9, fig. 9. Ecology: upper bathyal (Ingle, 1980; Resig, 1981). Resig (1981) finds this species associated with temperatures of $7-13^{\circ} \mathrm{C}$, a salinity range of $34.6 \%$, and an oxygen content of less than $1 \mathrm{ml} / \mathrm{L}$.
Epistominella umbonifera (Cushman)-Pulvinulinella umbonifera Cushman, 1933, Contr. Cushman Lab. Foram. Res., Vol. 9, p. 90, pl. 9 , fig. 9.

Eponides repandus (Fitchell and Moll)-Nautilus repandus Fitchell and Moll, 1798, Microscopische und andere kleine Schalthiere aus den Geschlectern Argonaute und Schiffer, p. 35, pl. 3, figs. a-d. Ecology: outer shelf (Smith, 1964). Pflum and Frerichs (1976) also note that this species is characteristic of tropical to warm-temperate shelf seas.

Fissurina alveolata (Brady) - Lagena alveolata Brady, 1884, Rept. Challenger Expedition (Zool.), Vol. 9, p. 487. pl. 60, figs, 30, 32. This paper, Pl. 2, Fig. 7.

Fissurina auriculata (Brady) - Lagena auriculata Brady, 1881, Q. J. Microsc. Sci., n.s., Vol. 21, p. 61.

Fissurina carteri (McLean)-Lagena (Entosolenia?) Carteri McLean, 1956, Bull. Am. Paleontol., Vol. 36, p. 330, pl. 39, fig. 13.

Fissurina cucullata Silvestri, 1902, Accad. Pont., Romana Nuovi Lincei., Vol. 19, p. 146, tf. 23-25.

Fissurina dominicana (Bermudez) - Lagena dominicana Bermudez, 1949, Cushman Lab. Foram. Res. Spec. Publ., no. 25, p. 116, pl. 11, figs. 2-3.

Fissurina exsculpta (Brady)-Lagena exsculpta Brady, Q. J. Microsc. Sci., n.s., Vol. 21 , p. 61.

Fissurina fimbrata (Brady)-Lagena fimbrata Brady, 1881, Q. J. Microsc. Sci., n.s., Vol. 21, p. 61 .

Fissurina globosa spinulosa (Reuss) - Lagena globosa (Montagu) spinulosa Reuss, 1870, K. Akad. Wiss. Wien, Math.-Naturwiss. Kl. Sitzber., Bd. 62, Abt. 1, p. 466.

Fissurina kugleri (Cushman and Stainforth)-Entosolenia kugleri Cushman and Stainforth, 1945, Cushman Lab. Foram. Res. Spec. Publ., no. 14 , p. 45 , pl. 7 , fig. 5 .

Fissurina marginata (Montagu)—Verminulum marginata Montagu, 1803, Testacea Britannica: Romsey, England (Hollis), p. 524.

Fissurina orbignyana Sequenza-Fissurina (Fissurine) orbignyana $\mathrm{Se}-$ quenza, 1862, Dei terreni Terziarii del distretto di Messina, Parte II: Italy (T. Capra), p. 66, pl. 2, figs. 25-26.

Fissurina solida Sequenza, 1862, Dei terreni Terziarii del distretto di Messina, Parte II: p. 56, pl. 1, fig. 42.

Fissurina spinosa (Sidebottom)-Lagena fascinata (Egger) spinosa Sidebottom, 1912, J. Quekett Microsc. Club, Ser. 2, Vol. 11 (19101912 ), no. 70 , p. 402 , pl. 17 , figs. 16 a-b.

Fissurina staphylleraria Schwager, 1866, Novara Exped. 1857-1859, Geol. Theil, Bd. 2, Abt. 2, p. 209, pl. 5, fig. 24. This paper, Pl. 2 , Fig. 10.

Fissurina subformosa Parr, 1950, Antarctic Research Exped. 19291931, Repts., Ser. B, Vol. 5, pt. 6, p. 313, pl. 9, figs. 9a-b. This paper, Pl. 2, Fig. 8.

Fissurina trigonomarginata (Parker and Jones)—Lagena sulcata Walker and Jacob var. trigono-marginata Parker and Jones, 1865, Philos. Trans. R. Soc. London, Vol. 155, p. 348, 352, 419, pl. 18, figs. 1a-b.

Fissurina ventricosa (Wiesner)-Lagena (Entosolenia) marginata (Montagu) venticosa Wiesner, 1931, in Drygalski, E. von (Ed.), Deutsche Sudpolar-Expedition 1901-1903 (Bd. 20 [Zool. Bd. 12]): Berlin u. Leipzig (de Grutter), p. 120, pl. 19, fig. 222.

Fissurina wiesneri Barker, 1960, Taxonomic Notes, Soc. Econ. Paleontol. Mineral. Spec. Publ., no. 9, p. 24, pl. 59, fig. 23.

Frondiculara compressa Costa, 1855, Mem. Accad. Sci Napoli, Vol. 2, p. 372 , pl. 3 , fig. 2 .

Frondicularia yaquensis Bermudez, 1949, Cushman Lab. Foram. Res. Spec. Publ., no. 25 , p. 160 , pl. 10, fig. 32 .

Fursenkoina bramletti (Galloway and Morrey)-Virgulina bramletti Galloway and Morrey, 1929, Bull. Amer. Paleontol., Vol. 15, no. 55 , p. 37 , pl. 5, fig. 14. This paper, Pl. 6, Fig. 1. Ecology: upper bathyal (Ingle, 1980).

Fursenkoina californiensis (Cushman)_Virgulina californiensis Cushman, 1925, Contr. Cushman Lab. Foram. Res., Vol. 1, no. 8, p. 32, pl. 5, fig. 11. Ecology: upper bathyal (Ingle, 1980).

Fursenkoina complanata (Egger)-Virgulina schreibersiana Czjzek complanata Egger, 1893, K. Bayer. Akad. Wiss., Math-Physik Kl., Abh., Bd. 18, Abt., 2, p. 292, pl. 8, figs. 91-92.

Fursenkoina cornuta (Cushman)-Virgulina cornuta Cushman, 1913, U.S. Nat. Mus. Proc., vol. 44, no. 1973, p. 637, pl. 80, fig. 1. This paper, Pl. 6, Fig. 2. 
Fursenkoina dibollensis (Cushman and Applin)_Virgulina dibollensis Cushman and Applin, 1926, Am. Assoc. Pet. Geol. Bull., Vol. 10 , p. 168 , pl. 7 , fig. 7 .

Fursenkoina fusiformis (Cushman)_Virgulina fusiformis Cushman, 1930, Florida State Geol. Surv. Bull., no. 4, p. 45, pl. 8, fig. 8.

Fursenkoina punctata (d'Orbigny) -Virgulina punctata d'Orbigny, 1839, in de la Sagra, R. (Ed.), Histoire physique et naturelle de l'ile de Cuba (Vol. 8): Paris (Bertrand), p. 139, pl. 1, figs. 35-36. Ecology: outer shelf (Smith, 1964).

Fursenkoina rotundata (Parr)-Virgulina rotundata Parr, 1950, Antarctic Research Exped. 1929-1931, Repts. (Adelaide), Ser. B, Vol. 5, Pt. 6, p. 337, pl. 12, fig. 14. This paper, Pl. 6, Fig. 3.

Fursenkoina seminuda (Natland)_Virgulina seminuda Natland, 1950, Scripps Inst. Oceanogr. Tech. Ser., Vol. 4, no. 5, p. 145, pl. 5, fig. 12. Ecology: upper middle bathyal (Bandy and Arnal, 1957).

Fursenkoina squammosa (d'Orbigny)-Virgulina squammosa d'Orbigny, 1826, Ann. Sci. Nat., Ser. 1, Vol. 7, p. 267, modeles no. 64.

Gaudryina arenaria Galloway and Wissler, 1927, J. Paleontol., Vol. 1, p. 68 , pl. 11, fig. 5. Ecology: outer shelf (Ingle, 1980).

Gaudryina atlantica (Bailey)-Textularia atlantica Bailey, 1851, Smithsonian Inst. Contr. Knowledge, Vol. 2, art. 3, p. 12, figs. 38-43, 67.

Gaudryina jacksonesis Cushman, 1926, Contr. Cushman Lab. Foram. Res., Vol. 2, p. 33, pl. 5, fig. 1.

Glandulina laevigata (d'Orbigny)-Nodosaria (Glandulina) laevigata d'Orbigny, 1826, Ann. Sci. Nat., Ser. 1, Vol. 7, p. 252, pl. 10, figs. 1-3. Ecology: Upper middle bathyal (Ingle, 1980).

Globobulimina barbata (Cushman)-Bulimina barbata Cushman, 1927, Scripps Inst. Oceanogr. Tech. Ser., Vol. 1, p. 151, pl. 2, fig. 11. This paper, Pl. 4, Fig. 2. Ecology: lower middle bathyal (Ingle and Keller, 1980).

Globobulimina pacifica Cushman, 1927, Contr. Cushman Lab. Foram. Res., Vol. 3, p. 67, pl. 14, fig. 12. This paper, Pl. 4, Fig. 1. Ecology: upper bathyal, shallow oxygen-minimum zone (Smith, 1964; Ingle, 1980; Ingle and Keller; 1980)

Globulimina spinifera (Cushman)-Bulimina spinifera Cushman, 1927, Scripps Inst. Oceanogr. Tech. Ser., Vol. 1, p. 151, pl. 2, fig. 15. Comments: Specimens assigned to this group have chambers which do not overlap as much as in G. barbata. The spines are also heavier and cover more of the test than in G. barbata.

Globocassidulina subglobosa (Brady) - Cassidulina subglobosa Brady, 1881, O. J. Microsc. Sci. (London), n.s., Vol. 21, p. 60. Ecology: upper bathyal. Depth, water-mass and biofacies associations of this species are highly variable. In the Gulf of Mexico, G. subglobosa occurs in the upper bathyal biofacies (Pflum and Frerichs, 1976); in the Atlantic Ocean, Lohman(1978) associates this species with a depth of $2.5 \mathrm{~km}$, and in the Pacific, Woodruff (in press) associated this species with shallow, early Miocene assemblages (less than $2.5 \mathrm{~km}$ ).

Goesella flintii Cushman, 1936, Cushman Lab. Foram. Res. Spec. Publ., no. 6, p. 34, pl. 5, fig. 8. Ecology: upper middle bathyal.

Goesella guraboensis Bermudez, 1949, Cushman Lab. Foram. Res. Spec. Publ., no. 25 , p. 88 , pl. 5 , figs. 1-4.

Guttulina caudata d'Orbigny, 1826, Ann. Sci. Nat., Vol. 7, p. 266.

Guttulina irregularis (d'Orbigny)-Globulina irregularis d'Orbigny, 1846, Die Fossilen Foraminiferen des Tertiaeren Beckens von Wien: (Gide et Comp.), p. 226, pl. 13, figs. 9-10.

Gyroidina altiformis Stewart and Stewart-Gyroidina soldanii d'Orbigny var. altiformis Stewart and Stewart, 1930, J. Paleontol., Vol. 4, p. 67, pl. 9, fig. 2. Ecology: lower middle bathyal (Smith, 1964). Ingle (1980) associates this species with the upper bathyal depths.

Gyroidina altispira Cushman and Stainforth, 1945, Cushman Lab. Foram. Res. Spec. Publ., no. 14, p. 61, pl. 11, fig. 1.

Gyroidina broeckhiana Karrer, 1878, in Drasche, Fragmente zu einer Geologie der Insel Luzon (Philippinen): (K. Gerold's Sohn), p. 98, pl. 5 , fig. 26.

Gyroidina condoni (Cushman and Schenck)-Eponides condoni Cushman and Schenck, 1928, Calif. Univ. Dept. Geol. Sci. Bull., Vol. 17 , p. 313 , pl. 44 , figs. $6-7$.

Gyroidina girardana (Reuss)-Rotalina giradana Reuss, 1851, Z. Deut. Geol. Ges., Bd. 3, p. 73, pl. 5, fig. 34 .

Gyroidina io Resig, 1958, Micropaleontology., Vol. 4, p. 304, tf. 15a-c.

Gyroidina lamarckiana d'Orbigny, 1839, in Barker-Webb, P. and Berthelot, S. (Eds.), Histoire Naturelle des l'iles Canaries (Vol. 2):
(Bethume), Pt. 2, Zool., p. 131, pl. 2, figs. 13-15. Ecology: lower middle bathyal. Pflum and Frerichs (1976) find this species living at $8010 \mathrm{Ft} .( \pm 2670 \mathrm{~m})$ in the Gulf of Mexico. Similar depths are noted in the southwest Pacific, where Burke (1981) finds $G$. Iamarckiana at depths of 1611-4332 m, associated with the deep oxygen-minimum zone. Off Central America, the deep oxygen-minimum zone impinges on the lower slope (Smith, 1964, Wyrtki, 1966).

Gyroidina medicea Emiliani, 1954, Paleontography., Vol. 48 (n.s., vol. 18) (1952-1953), p. 136, pl. 24, figs. 6a-c.

Gyroidina multilocula Coryell and Mossman-Gyroidina soldanii d'Orbigny multilocula Coryell and Mossman, J. Paleontol., Vol. 16, p. 237 , pl. 36, fig. 20. Ecology: upper middle bathyal (Smith, 1964). Off the North American coast, this species has an upper depth limit within the lower bathyal biofacies (Ingle, 1980).

Gyroidina neosoldanii Brotzen, 1936, Sver. Geol. Unders. Avh., Ser. C, no. 396 (Arsb. 30, no. 3), p. 158.

Gyroidina nitidula (Schwager)-Rotalia nitidula Schwager, 1866, Novara Exped. Geol. Theil, Bd. 2, Abt. 2, p. 263, pl. 7, fig. 110. Ecology: upper bathyal (Smith, 1964).

Gyroidina orbicularis d'Orbigny, 1826, Ann. Sci. Nat., Ser. 1, Vol. 7 , p. 278, modeles no. 13.

Gyroidina perampla Cushman and Stainforth-Gyroidina girardana (Reuss) perampla Cushman and Stainforth, 1945, Cushman Lab. Foram. Res. Spec. Publ., no. 14, p. 61, pl. 10, fig. 19.

Gyroidina planulata Cushman and Renz, 1941, Contr. Cushman Lab. Foram. Res., Vol. 17, p. 23, pl. 4, fig. 1. Ecology: abyssal. G. planulata is assigned to abyssal depths because it is associated with the early Miocene and middle-late Miocene bottom water (Woodruff, in press). The bottom water impinges on the Central American slope at depths of $3.5 \mathrm{~km}$ and greater.

Gyroidina quinqueloba Uchio, 1960, Cushman Found. Foram. Res. Spec. Publ., no. 5, p. 66, pl. 8, figs. 22-25.

Gyroidina rotundimargo Stewart and Stewart-Gyroidina soldanii d'Orbigny rotundimargo Stewart and Stewart, 1930, J. Paleontol., Vol. 4 , p. 68 , pl. 68 , pl. 9 , fig. 3 .

Gyroidina soldanii d'Orbigny, 1826, Ann. Sci. Nat., Ser. 1, Vol. 7, p. 278 , modeles no. 36. Ecology: lower bathyal (Ingle, 1980).

Gyroidina zelandica Finlay, 1939, Roy. Soc. New Zealand, Trans. Proc., Vol. 69 , Pt. 3, p. 323 , pl. 28 , figs. $138-140$

Hanzawaia basiloba (Cushman)-Truncatulina basiloba Cushman, 1918, U.S. Geol. Surv. Bull., no. 676, p. 64, pl. 21, fig. 2. Ecology: inner shelf (Ingle, 1980).

Hanzawaia concentrica (Cushman)-Truncatulina concentrica Cushman, 1918, U.S. Geol. Surv. Bull., no. 676, p. 64, pl. 21, fig. 3. Ecology: inner shelf (Smith, 1964).

Hanzawaia illingi (Nuttall)-Truncatulina illingi Nuttall, 1928, Q. J. Geol. Soc. London, Vol. 84, p. 99, pl. 7, figs. 11, 17, p. 99, tf. 5 . Ecology: outer shelf (Ingle, 1980).

Hanzawaia isidroensis (Cushman and Renz)-Cibicides isidroensis Cushman and Renz, 1941, Contr. Cushman Lab. Foram. Res., Vol. 17, p. 26, pl. 4, fig. 10.

Hanzawaia mantaensis (Galloway and Morrey)-Anomalina mantaensis Galloway and Morrey, 1929, Bull. Amer. Paleontol., Vol. 15, p. 28 , pl. 4 , figs. $5 \mathrm{a}-\mathrm{c}$.

Hanzawaia nitidula (Bandy)-Cibicidina basiloba (Cushman) nitidula Bandy, 1953, J. Paleontol., Vol. 27, p. 178, pl. 22, fig. 3.

Hoeglundina elegans (d'Orbigny)-Rotalia elegans d'Orbigny, 1826 , Ann. Sci. Nat., Vol. 7, p. 276, modeles no. 6. Ecology: upper bathyal (Smith, 1964, Ingle 1980).

Karreriella alticamerata Cushman and Stainforth, 1945, Cushman Lab. Foram. Res. Spec. Publ., no. 14, p. 19, pl. 2, fig. 10.

Karreriella bradyi (Cushman)-Gaudryina bradyi Cushman, 1911, U.S. Nat. Mus. Bull., no. 71 , p. 67 , tf. 107. This paper, Pl. 1, Fig. 4. Ecology: outer shelf (Pflum and Frerichs, 1976).

Karreriella chilostoma (Reuss)-Textularia chilostoma Reuss, 1852, Z. Deut. Geol., Ges., Bd. 4, p. 18, tf. a-b.

Lagena becki Sullivan, 1962, Calif. Univ. Publs. Geol. Sci., Vol. 37, p. 266 , pl. 10 , figs. $16 \mathrm{a}-\mathrm{b}$.

Lagena castrensis Schwager, 1866, Novara Exped. 1857-1859, Geol. Theil, Bd. 2, Abt. 2, p. 208, pl. 5, fig. 22.

Lagena costata (Williamson)-Entosolenia costata Williamson, 1858, On the Recent Foraminifera of Great Britain: London (R. Soc.), p. 9, pl. 1, fig. 18. This paper, Pl. 2, Fig. 2. 
Lagena crenulata capistriata Cushman and Stainforth-Lagena crenata Parker and Jones capistrata Cushman and Stainforth, 1945, Cushman Lab. Foram. Res. Spec. Publ., no. 14, p. 30. pl. 4, fig. 16.

Lagena elongata (Ehrenberg)-Miliola elongata Ehrenberg, 1844, $K$. Preuss. Akad. Wiss. (Berlin), p. 371.

Lagena gracillima (Sequenza)-Amphorina gracillima Sequenza, 1862, Dei terreni Terziarii del distretto di Messina, Parte II: Messina, Italy (T. Capra), p. 51, pl. 1, fig. 37.

Lagena hexagona (Williamson)-Entosolenia squamosa (Montagu) var. $\gamma$ hexagona Williamson, 1848, Ann. Mag. Nat. Hist. (England), Ser. 2, Vol. 1, p. 20 , pl. 2, fig. 23.

Lagena hispida Reuss, 1863, K. Akad. Wiss. Wien, Math.-Naturwiss. Kl., Sitzber., Bd. 46, Abt. 1, p. 335, pl. 6, figs. 77-79.

Lagena laevis (Montagu)-Vermiculum laeve Montagu, 1803, Testacea Britannica, Romsey, England (Hollis), p. 524.

Lagena limbata Matthes, 1939, Palaeontography, Bd. 90, Abt. A, p. 81, pl. 6, fig. 112 .

Lagena lineata (Williamson)-Entosolenia lineata Williamson, 1848 , Ann. Mag. Nat. Hist. (England), Ser. 2, Vol. 1, p. 18, pl. 2, fig. 18.

Lagena meridionalis Wiesner-Lagena gracilis Williamson meridionalis Wiesner, 1931, in Drygalski, E. von (Ed.), Deutsche SudpolarExpedition, 1901-1903 (Bd. 20), (Zool., Bd. 12): p. 117, pl. 18 fig. 211.

Lagena mollis Cushman-Lagena gracillima (Sequenza) mollis Cushman, 1944, Cushman Lab. Foram. Res. Spec. Publ. no. 12, p. 21, pl. 3 , fig. 3 .

Lagena nuttalli Galloway and Heminway, 1928, N.Y. Acad. Sci., Sci. Survey Puerto Rico and Virgin Islands, Vol. 3, Pt. 4, p. 346, pl. 10. fig. 8 .

Lagena semilineata Wright, 1886, Belfast Nat. Field Club Proc. (Ireland), n.s. Vol. 1, appendix 9 , p. 320 , pl. 26, fig. 7.

Lagena semistriata Williamson-Lagena striata (Montagu) var. semistriata Williamson, 1848, Ann. Mag. Nat. Hist. (England), Ser. 2, Vol. 1, p. 14, pl. 1, figs. 9-10.

Lagena setigera Millett-Lagena clavata (d'Orbigny) setigera Millett, 1901, J. R. Microsc. Soc. London, p. 491, pl. 8, fig. 9.

Lagena striata (d'Orbigny)-Oolina striata d'Orbigny, 1839, Voyage dans l'Amerique Meridionale: Foraminiferes (Vol. 5): p. 21, pl. 5, fig. 12. This paper, Pl. 2, Fig. 4.

Lagena vulgaris Williamson, 1858, On the Recent Foraminifera of Great Britain: London (R. Soc.), p. 3, pl. 1, figs. 5-5a.

Laticarinina pauperata (Parker and Jones)-Pulvinulina repanda menardii pauperata Parker and Jones, 1865, Philos. Trans. R. Soc. London, Vol. 155, p. 395, pl. 16, figs. 50, 51a-b. This paper, Pl. 4, Fig. 13. Ecology: lower middle bathyal (Ingle, 1980). In the early Miocene, Douglas (1980) and Woodruff (in press) associate this species with depths of greater than $3000 \mathrm{~m}$ and the Antarctic Bottom Water.

Lenticulina alatolimbatus (Gumbel)-Robulina alato-limbata Gumbel, 1868, K. Bayer. Akad. Wiss. München, Math.-Physik. Kl. Abh., Bd. 10, Abt. 2, p. 641, pl. 1, fig. 70.

Lenticulina arcuatostriata (Hantken)-Cristellaria (Robulina) arcuato-striata Hantken, 1868, Magyarh. Foldt. Tars., Munk (Pest, Magyarorszag), Vol. 4, p. 93, pl. 2, figs. 30a-c.

Lenticulina arcuatostriatus carolinianus (Cushman)-Robulus arcuato-striatus (Hantken) carolinianus Cushman, 1933, Contr. Cushman Lab. Foram. Res., Vol. 9, p. 4, pl. 1, fig. 9.

Lenticulina calcar (Linné)-Nautilus calcar Linné, 1758, Systemma Naturae (Vol. 1, 10th Ed.), p. 709.

Lenticulina caritae Bermudez, 1949, Cushman Lab. Foram. Res. Spec. Publ., no. 25, p. 122, pl. 7, figs. 35-36. This paper, Pl. 1, Fig. 10.

Lenticulina colorata (Stache)-Cristellaria (Cristellaria) colorata Stache, 1865, Novara Exped. 1857-1859, Geol. Theil., Bd. 1, Abt. 2, p. 229 , pl. 23 , fig. 9 .

Lenticulina convergens (Bornemann)-Cristellaria convergens Bornemann, 1855, Z. Deut. Geol Ges., Bd. 7, Heft 2, p. 327, pl. 13, figs. 16-17.

Lenticulina crassa d'Orbigny, 1846, Die fossilen foraminiferen des tertiaeren Beckens von Wien: (Gide et Comp.), p. 90, pl. 4, figs. 1-3.

Lenticulina cushmani (Galloway and Wissler)-Robulus cushmani Galloway and Wissler, 1927, J. Paleontol., Vol. 1, p. 51, pl. 8, fig. 11. Ecology: outer shelf (Uchio, 1960).

Lenticulina dicampyla (Franzenau)-Cristellaria dicampyla Franzenau, Math. term. Kozl. (Hungary), Kot. 26, szam 1, p. 13, pl. 1, figs. $8 \mathrm{a}-\mathrm{b}$. This paper, Pl. 1, Fig. 10.
Lenticulina gibba d'Orbigny-Cristellaria gibba d'Orbigny, 1839, in de la Sagra, R. (Ed.), 1839, Histoire physique et naturelle de L'ile de Cuba, (Vol. 8): Paris (Bertrand), p. 40, (plate published separately) pl. 7 , figs. $20-21$.

Lenticulina gutticostatus cocoaensis (Cushman)-Cristellaria gutticostatus (Gumbel) cocoaensis Cushman, 1925, Contr. Cushman Lab. Foram. Res., Vol. 1, p. 67, pl. 10, fig. 11.

Lenticulina iota (Cushman)-Cristellaria iota Cushman, 1923, U.S. Nat. Mus. Bull., 104, p. 111, pl. 29, fig. 2, pl. 30. fig. 1. This paper, Pl. 1, Fig. 11.

Lenticulina limbosa (Reuss)-Robulus limbosus Reuss, 1863, K. Akad. Wiss., Math.-Naturwiss., Kl., Bd. 48, Abt. 1, p. 55, pl. 6, figs. $69 \mathrm{a}-\mathrm{b}$.

Lenticulina melvilli (Cushman and Renz)-Robulus melvilli Cushman and Renz, 1941, Contr. Cushman Lab. Foram. Res., Vol. 17, p. 12, pl. 2, fig. 12 .

Lenticulina miocenica (Chapman)-Cristellaria miocenica Chapman, 1900, Calif. Acad. Sci., Proc., Geol., Ser. 3, Vol. 1 (1897-1904), p. 250 , pl. 30 , figs. $1-1 \mathrm{a}$.

Lenticulina nikobarensis (Schager)-Cristellaria nikobarensis Schwager, 1866, Novara Exped., 1857-1859, Geol. Theil., Bd. 2, Abt. 2, p. 243 , pl. 6 , fig. 87 .

Lenticulina occidentalis (Cushman)-Cristellaria occidentalis Cushman, 1923, U.S. Nat. Mus. Bull., no. 104, p. 102, pl. 25, fig. 2, pl. 26, figs. 1-2.

Lenticulina occidentalis glabrata (Cushman)-Cristellaria occidentalis Cushman glabrata Cushman, 1923, U.S. Nat. Mus. Bull., no. 104, p. 103, pl. 25, fig. 3 .

Lenticulina occidentalis torrida (Cushman)-Cristellaria occidentalis Cushman torrida Cushman, 1923, U.S. Nat. Mus. Bull., no. 104, p. 105 , pl. 25 , fig. 1 .

Lenticulina peregrina matanzana (Palmer and Bermudez)-Cristellaria peregrina (Schwager) matanzana Palmer and Bermudez, 1936, Mem. Soc. Cubana Hist. Nat., Vol. 10, p. 254, pl. 13, fig. 5.

Lenticulina plummerae (Cole)-Robulus plummerae Cole, 1928, Bull. Amer. Paleontol., Vol. 14, p. 208, pl. 34, fig. 10.

Lenticulina rotulata Lamarck-Lenticulinites rotulata Lamarck, 1804 , Paris Mus. Nat. hist. Nat. Ann., (An XIII), tome 5, Vol. 8, p. 188, pl. 62 , fig. 11.

Lenticulina subkubinyii (Nuttall)—Cristellaria subkubinyii Nuttall, 1932, J. Paleontol., Vol. 6, p. 11, pl. 1, fig. 16.

Lenticulina submamilligera (Cushman)-Cristellaria submamilligera Cushman, 1917, U.S. Nat. Mus. Proc., Vol. 51, p. 657.

Lenticulina subpapillosa (Nuttall)-Cristellaria subpapillosa Nuttall, 1932, J. Paleontol., Vol. 6, p. 12, pl. 1, fig. 12.

Lenticulina terryi (Coryell and Embich)-Robulus terryi Coryell and Embich, 1937, J. Paleontol., Vol. 11, p. 299, pl. 41, figs. 17a-b.

Lenticulina texana (Cushman and Applin)-Cristellaria articulata Reuss texana Cushman and Applin, 1926, Am. Assoc. Pet. Geol. Bull., Vol. 10, p. 170, pl. 8, figs. la-b, 2.

Lenticulina vaughani (Cushman)-Cristellaria vaughani Cushman, 1918, U.S. Nat. Mus. Bull., no. 103, p. 61, pl. 22, fig. 3.

Lenticulina yaquensis (Bermudez)-Robulus yaquensis Bermudez, 1949, Cushman Lab. Foram. Res. Spec. Publ., no. 5, p. 132, 132, pl. 6, figs. 61-66.

Marginulina abbreviata Neugeboren, 1851, Siebenb. Ver. Naturwiss. Hermannstadt, Verh. Mitt. (Hermannstadt, Hungary), Jahrg. 2, no. 8 , p. 129 , pl. 5 , fig. 4 .

Marginulina alazaensis Nuttall, 1932, J. Paleontol., Vol. 6, p. 13, pl. 3, figs. 3 and 7.

Marginulina asperuliformis (Nuttall)-Cristellaria asperuliformis Nuttall, 1930, J. Paleontol., Vol. 4, p. 282, pl. 23, figs. 9-10.

Marginulina dominicana Bermudez, 1949, Cushman Lab. Foram. Res. Spec. Publ., no. 25, p. 140, pl. 9, fig. 26.

Marginulina dubia Neugeboren, 1851, Siebenb. Ver. Naturwiss. Hermannstadt (Hungary), Jahrg. 2, p. 120, pl. 4, fig. 1.

Marginulina exima Neugeboren, 1851, Siebenb. Ver. Naturwiss. Hermannstadt (Hungary), Jahrg. 2, p. 129, pl. 4, fig. 17.

Marginulina senni (Cushman and Renz)-Robulus senni Cushman and Renz, 1941, Contr. Cushman sab. Foram. Res., Vol. 17, p. 12, pl. 2, figs. 14-15.

Marginulina subbullata Hantkeni, 1875, K. Ungar. Geol. Anst., Mitt. Jahrb. (Hungary), Bd. 4, Heft 1, p. 46, pl. 4, figs. 9-10, pl. 5, fig. 9.

Marginulina sublituus (Nuttall)-Cristellaria sublituus Nuttall, 1932, J. Paleontol., Vol. 6, p. 11, pl. 1, figs. 13-14. 
Marginulina subrecta Franke, 1927, Danmarks Geol. Unders., Raekke 2, Nr. 46, p. 19, pl. 1, fig. 28.

Marginulina yaquatensis Bermudez, 1949, Cushman Lab. Foram. Res. Spec. Publ., no. 25, p. 142, pl. 9, fig. 29.

Martinotiella bradyana (Cushman)-Listerella bradyana Cushman, 1936, Cushman Lab. Foram. Res. Spec. Publ., no. 6, p. 40, pl. 6, fig. 11. Ecology: abyssal (Ingle and Keller, 1980).

Martinotiella communis (d'Orbigny) - Clavulina communis d'Orbigny, 1846, Die Fossilen Foraminiferes des Tertiaeren Beckens von Wien: (Gide et Comp.), p. 196, pl. 12, figs. 1-2. Ecology: upper bathyal, shallow oxygen-minimum zone (Ingle and Keller, 1980).

Martinotiella pallida (Cushman)_Clavulina communis (d'Orbigny) pallida Cushman, 1927, Scripps Inst. Oceanogr. Tech. Ser., Vol. 1, p. 138 , pl. 2, fig. 1 .

Melonis affinis (Reuss)-Nonionina affinis Reuss, 1851, Z. Deut. Geol. Ges., Bd. 3, p. 72, pl. 5, fig. 32. Ecology: lower middle bathyal (Smith, 1964). Woodruff and Douglas (1981) note that $M$. barleanus (M. affinis of this study) is found at depths greater than $3.5 \mathrm{~km}$ before 15.5 $\mathrm{Ma}$ and $1.5-4.0 \mathrm{~km}$ after $14 \mathrm{Ma}$ ago. This depth change has been included in the Leg 84 faunal analysis.

Melonis soldanii (d'Orbigny)-Frerichs, 1969, Contr. Geol. Univ. Wyoming, Vol. 8, figs. 1a-c, 4,5 .

Melonis pompilioides (Fitchell and Moll)—Nautilus pompilioides Fitchel and Moll, 1798, Testacea Microscopia Aliaque Minuta ex Generibus Argonauta et Nautilus (Austria), p. 31, pl. 2, figs. a-c. Ecology: lower bathyal (Ingle, 1980; Ingle and Keller, 1980).

Milliammina fusca (Brady)-Quinqueloculina fusca Brady, 1870, Ann. Mag. Nat. Hist. (England), Ser, 4, Vol. 6, p. 286, pl. 11, figs. 2-3.

Miliolinella circularis (Bornemann)-Triloculina circularis Bornemann, 1855. Z. Deut. Geol. Ges., Bd. 7, Heft 2, p. 349, pl. 19, fig. 4. Ecology: inner shelf (Poag, 1981).

Nodogenerina challengeriana Thalmann, 1937, Eclogae Geol. Helv., Vol. 30 , p. 341.

Nodogenerina laevigata Bermudez, 1949, Cushman Lab. Foram. Res. Spec. Publ., no. 25, p. 179, pl. 11, fig. 59.

Nodosarella subnodosa (Guppy)-Ellipsoidina subnodosa Guppy, 1894, Proc. Zool. Soc. London, p. 650, pl. 41, fig. 12.

Nodosaria calomorpha Reuss, 1866, K. Akad. Wiss. Wien. Math.Naturwiss. Kl., Denkschr., Bd. 25, Abt. 1, p. 129, pl. 1, figs. 15-19.

Nodosaria caribbeana Hedberg-Nodosaria raphanistum (Linné) caribbeana Hedberg, 1937, J. Paleontol., Vol. 11, p. 671, pl. 91, fig. 1.

Nodosaria elegantissima Hantken, 1875, K. Ungar. Geol. Anst. Mitt. Jahrb. (Hungary), Bd. 4, Heft. 1, p. 24, pl. 12, fig. 16.

Nodosaria fistuca Schwager, 1866, Novara Exped. 1837-1839, Geol. Theil, Bd. 2, Abt. 2, p. 216, pl. 5, figs. 36-37.

Nodosaria hispida d'Orbigny, 1846, Die Fossilen Foraminiferen des Tertiaeren Beckens von Wien: (Gide et Comp.), p. 35, pl. 1, figs. 24-25.

Nodosaria lamellata Cushman and Jarvis, 1945, Cushman Lab. Foram. Res. Spec. Publ., no. 14, p. 24.

Nodosaria latejugata Gumbel, 1868, K. Bayer. Akad. Wiss. München, Math.-Physik. Kl., Abh., Bd. 10, Abt. 2, p. 619, pl. 1, fig. 32.

Nodosaria longiscata d'Orbigny, 1846, Die Fossilen Foraminiferen des Tertiaeren Beckens von Wien: (Gide et Comp.), p. 32, pl. 1, figs. $10-12$.

Nodosaria nuttalli Hedberg, 1937, J. Paleontol., Vol. 11. p. 673, pl. 91, fig. 6 .

Nodosaria obliqua (Linné)—Nautilus obliquus Linneaus. 1767, Systemma Naturae (Vol. 1, 10th Ed.), 1758, p. 710.

Nodosaria parexilis Cushman and Stewart, 1930, in Cushman, Stewart and Stewart, 1930, San Diego Soc. Nat. Hist. Trans., Vol. 6, p. 55.

Nodosaria cf. N. perversa (Schwager) of Uchio, 1960, Cushman Found. Foram. Res. Spec. Publ., no. 5, pl. 4, fig. 1.

Nodosaria pyrula d'Orbigny, 1826, Ann. Sci. Nat. France, Ser. 1, tome 7, p. 253.

Nodosaria stainforthia Cushman and Renz, 1941, Contr. Cushman Lab. Foram. Res., Vol. 17, p. 15, pl. 3, fig. 4.

Nodorsaria vertebralis (Batsch)-Nautilis (Ortoceras) vertebralis Batsch, 1791, Sechs Kupfertafeln mit Conchylien des Seesandes Jena: University Press, p. 2, 5, pl. 2, figs. 6a-b.

Nonionella auricula Heron-Allen and Earland, 1930, J. Microsc. Soc. (London), Ser. 3, Vol. 50, p. 192, pl. 5, figs. 68-70.
Nonionella basispinata (Cushman and Moyer)-Nonion pizarrense Berry basispinata Cushman and Moyer, 1930, Contr. Cushman Lab. Foram. Res., Vol. 6, p. 54, pl. 7, fig. 18. Ecology: inner shelf (Smith, 1964; Ingle, 1980).

Nonionella incisa (Cushman)-Nonionina incisa Cushman, 1926, Contr. Cushman Lab. Foram. Res., Vol. 1, p. 90. Ecology: inner shelf (Ingle, 1980).

Nonionella labradorica (Dawson)-Nonionina labradorica Dawson, 1860, Can. Nat., Vol. 5, p. 191, tf. 4.

Nonionella miocenica Cushman, 1926, Contr. Cushman Lab. Foram. Res., Vol. 2, p. 64. Ecology: inner shelf (Smith, 1964; Ingle, 1980).

Nonionella puchella Hada, 1931, Tohoku Imp. Univer. Sci. Repts. (Sendai, Japan), Ser. 4 (Biol.), Vol. 6, p. 120, tf. 79a-c.

Nonionella stella Cushman and Moyer-Nonionella miocenica Cushman stella Cushman and Moyer, 1930, Contr. Cushman Lab. Foram. Res., Vol. 6, p. 56, pl. 7, fig. 17. Ecology: inner shelf (Ingle, $1980)$. Ingle and Keller (1980) associate this species with shallow oxygen-minimum zone. The shallower upper depth limit was used in this study.

Oolina caudigera (Weisner)-Lagena (Entosolenia) globosa (Montaqu) caudiger Weisner, 1931, in Drygalski, Deutsche Sudpolar-Expedition 1901-1903 (Bd. 20 [Zool. Bd. 12]): Berlin u. Leipzig (de Gruyter), p. 119, pl. 18, figs. 214.

Oolina desmophora (Rymer Jones) - Lagena vulgaris desmophora $\mathbf{R y -}$ mer Jones, 1874, Linnaean Soc. London Trans., Vol. 30, p. 54, pl. 19, figs. 23-24.

Oolina melo d'Orbigny, 1839, Voyage dans I'Amerique Meridionale: Foraminiferes (Vol. 5): (Levrault), 1839, p. 20, pl. 5, fig. 9.

Oolina squamosa (Montagu)-Vermiculum squamosum Montagu, 1893, Testacea Britannica: p. 526, pl. 14, fig. 2.

Oolina striatopunctata (Parker and Jones)-Lagena sulcata (Walker and Jacob) striatopunctata Parker and Jones, 1865, Philos. Trans. R. Soc. London, Vol. 155, p. 350, pl. 13, figs. 25-27.

Oridorsalis multiseptus (Koch)-Pulvinulina umbonata (Reuss) multisepta Koch, 1926, Eclogae Geol. Helv., Vol. 19, p. 749, tf. 25.

Oridorsalis subtenera (Galloway and Wissler)—Rotalia subtenera Galloway and Wissler, 1927, J. Paleontol., Vol. 1, p. 60, pl. 10. fig. 4. Ecology: upper middle bathyal (Ingle, 1980).

Oridorsalis umbonatus (Reuss)-Rotalia umbonata Reuss, 1851, Z. Deut. Geol. Ges., Bd. 3, p. 75, pl. 5, fig. 35. This paper, Pl. 6, Fig. 11.

Orthomorphina rohri (Cushman and Stainforth)—Nodogenerina rohri Cushman and Stainforth, 1945, Cushman Lab. Foram. Res. Spec. Publ., no. 14, p. 39, pl. 5, fig. 26.

Osangularia culteri (Parker and Jones) - Planorbulina farcta (Fitchel and Moll) ungeriana (d'Orbigny) culteri Parker and Jones, 1865, Philos. Trans. R. Soc. London, Vol. 155, p. 382, 421, pl. 19, figs. 1a-b. This paper, Pl. 6, Fig. 12. Ecology: upper middle bathyal (Pflum and Frerichs, 1976).

Osangularia mexicana (Cole)-Pulvinulinella culteri (Parker and Jones) mexicana Cole, 1927, Bull. Amer. Paleontol., Vol. 14, p. 31, pl. 1, figs. 15-16.

Parafissurina cf. "Lagena" fistulifera Buchner of Parker, 1964, J. Paleontol., Vol. 38, p. 627, pl. 99, fig. 17.

Parafissurina fusuliformis Loeblich and Tappan, 1953, Smithsonian Inst. Misc. Coll., Vol. 121, p. 79, pl. 14, figs. 18-19.

Palmerinella thalmani Stainforth and Stevenson, 1946, J. Paleontol., Vol. 20, p. 563, pl. 86, figs. 7-10.

Palnularia caribbeana Bermudez, 1949, Cushman Lab. Foram. Res. Spec. Publ., no. 25, p. 136, pl. 8, figs. 49-50.

Planularia crepidula (Fitchel and Moll)-Nautilus crepidulus Fitchel and Moll, 1798, Testacea Microscopia Aliaque Minuta ex-Generibus Argonauta et Nautilus: p. 107, pl. 19, figs. g-i.

Planularia venezuelana Hedberg, 1937, Jour. Paleo., vol. 11, p. 670, pl. 90, fig. 14.

Planulina exorna Phleger and Parker, 1951, Mem. Geol. Soc. Am., no. 46, p. 32, pl. 18, figs. 5-7. This paper, Pl. 5, Fig. 6. Ecology: outer shelf (Smith, 1964).

Planulina marialana Hadley, 1934, Bull. Am. Paleontol., Vol. 20, p. 27, pl. 4, figs. 4-6.

Planulina mexicana Cushman, 1927, Contr. Cushman Lab. Foram. Res., Vol. 3, p. 113, pl. 23, fig. 5.

Planulina ornata (d'Orbigny)-Truncatulisa ornata d'Orbigny, 1839. Voyage dans l'Amerique Meridionale: Foraminiferes (Vol. 5): p. 40, 
pl. 6, figs. 7-9. This paper, PI. 5, Fig. 7. Ecology: upper middle bathyal (Smith, 1964). Ingle (1980) uses an upper depth limit of outer shelf, but the deeper limit was used in this study.

Planulina $\mathrm{cf}$. P. ornata d'Orbigny. Comments: Specimens assigned to this group are smaller, less perforate, and have more limbate sutures than typical.

Plamulina renzi Cushman and Stainforth, 1945, Cushman Lab. Foram. Res. spec. Publ., no. 14, p. 72 , pl. 15, fig. 1. This paper, Pl. 5, Fig. 8.

Plectofrondicularia advena (Cushman)-Frondicularia advena Cushman, 1922, U.S. Nat. Mus. Bull., no. 104, p. 141, pl. 20, figs. 1-2. Ecology: lower bathyal (Cushman, 1922).

Plectofrondicularia californica Cushman and Stewart, 1926, Contr. Cushman Lab. Foram. Res., Vol. 2. p. 39, pl. 6, figs. 9-11. This paper, Pl. 2, Fig. 5.

Plectofrondicularia keijzeri Bermudez, 1949, Cushman Lab. Foram. Res. Spec. Publ., no. 25, p. 175 , pl. 11, figs. $49,51$.

Plectofrondicularia miocenica Cushman, 1926, Contr. Cushman Lab. Foram. Res., Vol. 2, p. 58, pl. 7, figs. 10-11, pl. 8, figs. 11-12. Ecology: lower bathyal (Ingle, 1980).

Plectofrondicularia morreyae Cushman, 1929, Contr. Cushman Lab. Foram. Res., Vol. 5, p. 92, pl. 13, fig. 23 .

Plectofrondicularia nuttalli Cushman and Stainforth, 1945, Cushman Lab. Foram. Res. Spec. Publ., no. 14, p. 38, pl. 5, figs. 21-23.

Plectofrondicularia ruthvanmurrayi Cushman and Stainforth, 1945, Cushman Lab. Foram. Res. Spec. Publ., no. 14, p. 37, pl. 5, fig. 14.

Plectofrondicularia vaughani Cushman, 1927, Contr. Cushman Lab. Foram. Res., Vol. 3, p. 112, pl. 23, fig. 3. This paper, Pl. 2, Fig. 6.

Plectofrondicularia yumuriana Palmer, 1940, Mem. Soc. Cubana Hist. Nat., Vol. 14, p. 294, pl. 53, figs. 3-4.

Pleurostomella. Most modern species of Pleurostomella occur at abyssal depths (Pflum and Frerichs, 1976). Unless otherwise noted, this is the depth-association adopted in this study.

Pleurostomella acuminata Cushman, 1922, U.S. Nat. Mus. Bull., no. 104 , p. 50 , pl. 19 , fig. 6 .

Pleurostomella acuta Hatken, 1875, K. Ungar. Geol. Anst., Mitt. Jahrb. (Hungary), Bd. 4, Heft 1, p. 44, pl. 13, fig. 18.

Pleurostomella alternans Schwager, 1866. Novara Exped. 1857-1859, Geol. Theil, Bd. 2, Abt. 2, p. 238, pl. 6, figs. 79-80.

Pleurostomella bierigi Palmer and Bermudez, 1936, Mem. Soc. Cubana Hist. Nat., Vol. 10, p. 294, pl. 17, figs. 7-8.

Pleurostomella brevis Schwager, 1866, Novara Exped. 1857-1859, Geol. Theil, Bd. Abt. 2, p. 239, pl. 6, fig. 81 .

Pleurostomella elliptica Galloway and Heminway, 1941, N.Y. Acad. Sci., Sci. Survey Puerto Rico and Virgin Islands, Vol. 3, p. 438, pl. 35 , fig. 3.

Pleurostomella jacksonensis Cushman and Applin, 1926, Am. Assoc. Pet. Geol. Bull., Vol. 10, p. 168, pl. 7, fig. 9.

Pleurostomella narajoensis Cushman and Bermudez, 1937, Contr. Cushman Lab. Foram. Res., Vol. 13, p. 16, pl. 1, figs 59-60.

Pleurostomella praegerontica Cushman and Stainforth, 1945, Cushman Lab. Foram. Res. Spec. Publ., no. 14, p. 52, pl. 8, figs. 13-14.

Praeglobobulimina affinis (d'Orbigny)-Bulimina affinis d'Orbigny, 1839, in de la Sagra, R. (Ed.), Histoire physique et naturelle de l'ile de Cuba (Vol. 8): Paris (Bertand), p. 105, pl. 2, figs. 25-26. This paper, Pl. 4 Figs. 3-4. Ecology: upper middle bathyal (Ingle, 1980).

Praeglobobulimina auriculata (Bailey)-Bulimina auriculata Bailey, 1851, Smithsonian Inst. Contr. Knowledge, Vol. 2, art. 3, p. 12, figs. 25-27.

Praeglobobulimina ovata (d'Orbigny)-Bulimina ovata d'Orbigny, 1846, Foraminiféres fossiles du bassin tertiaire de Vienne (Autriche) (Die fossilem foraminiferon des tertiaeren Beckens von Wien): Paris (Gide et Comp)., p. 185, pl. 11, figs. 13-14.

Praeglobobulimina ovula (d'Orbigny)-Bulimina ovula d'Orbigny, 1839, Voyage dans l'Amerique Meridionale: Foraminiferes (Vol 5): Pt. 5, p. 51, pl. 1, figs. 10-11. Ecology: upper middle bathyal (Globobulimina ovula of Ingle, 1980).

Praeglobobulimina pupoides (d'Orbigny)—Bulimina pupoides d'Orbigny, 1846, Foraminiferes fossiles du basin tertiare de Vienne: (Gide et Cie), p. 185, pl. 11, figs. 11-12.

Pseudonodosaria conica (Neugeboren)-Glandulina conica Neugeboren, 1850, Siebenb. Ver. Naturwiss. Hermannstadt (Hungary), Jahrg. 1 , no. 4 , p. 51 , pl. 1 , fig. 5a-b.
Pseudonodosaria inflata (Bornemann)-Glandulina inflata Bornemann, 1855, Z. Deut. Geol. Ges., Bd. 7, Heft 2, p. 320, pl. 12, figs. 6-7.

Pseudonodosaria obsolete (Acosta)-Nodogerina obsoleta Acosta, 1940, Algunos Foraminiferos Nuevos de las Costas Cubanas: La Habana (Torreia), num. 5, p. 5, pl. 1, fig. 8 .

Pullenia alazaensis Cushman, 1927, J. Paleontol., Vol. 1, p. 168, pl. 26, figs. 14-15.

Pullenia bulloides (d'Orbigny)—Nonionina bulloides d'Orbigny, 1846, Die Fossilen Foraminiferen des Tertiaeren Beckens von Wien: (Gide et Comp.), p. 107, pl. 5, figs. 9-10. Ecology: lower middle bathyal (Smith, 1964; Ingle, 1980; Ingle and Keller, 1980). Pflum and Frerichs (1976) also reported rare occurrences of this species at upper bathyal depths.

Pullenia duplicata Stainforth, 1949, J. Paleontol., Vol. 23, p. 436. Ecology: lower middle bathyal. This species has been assigned to the lower middle bathyal biofacies because of its morphological similarity to Pullenia bulloides.

Pullenia malkinae Coryell and Mossman, 1942, J. Paleontol., Vol. 16, p. 234, pl. 36, figs. 3-4. Ecology: outer shelf (Ingle, 1980).

Pullenia quatriloba (Sequenza)-Nonionina quatriloba Sequenza, 1880, Mem. R. Accad. Lincei, Rome, Cl. Sci. Fis., Mat., Nat., Ser. 3, Vol. 6, p. 430, and errata, pl. 17, fig. 15 .

Pullenia quinqueloba (Reuss)-Nonionina quinqueloba Reuss, 1851, Z. Deut. Geol. Ges., Bd. 3, p. 71, pl. 5, fig. 31. Ecology: upper middle bathyal (Pflum and Frerichs, 1976, Ingle, 1980).

Pullenia riveroi Bermudez, 1949, Mem. Soc. Cubana Hist. Nat., Vol. 13 , p. 11, pl. 2, figs. 1-6.

Pullenia cf. P. riveroi Bermudez. Comments: Specimens assigned to this group have \pm 7 chambers. Chambers are very inflated, and increase in size as added. Test is asymmetric instead of smoothly rounded as in the typical form. Test is also more robust and fatter than $P$. trinitatensis.

Pullenia salisburyi Stewart and Stewart, 1930, J. Paleontol., Vol. 4, p. 72 , pl. 8, fig. 2. Ecology: upper bathyal (Smith, 1964). Ingle (1980) cites the upper depth limit of this species as outer shelf; the deeper limit was used in this study.

Pullenia trinitatensis Cushman and Stainforth, 1945, Cushman Lab. Foram. Res. Spec. Publ., no. 14, p. 66, pl. 12, fig. 11. Ecology: middle bathyal (Pflum and Frerichs, 1976).

Pyrgo depressa (d'Orbigny)-Biloculina depressa d'Orbigny, 1826, Ann. Sci. Nat. (France), Ser. 1, tome 7, p. 298, modeles no. 91. This paper, Pl. 1, Fig. 8. Ecology: upper middle bathyal (Pflum and Frerichs, 1976)

Pyrgo murrhina (Schwager)-Biloculina murrhina Schwager, 1866, Novara Exped. 1857-1859, Geol. Theil, Bd. 2, Abt. 2, p. 203, pl. 4, fig. 15. Ecology: lower middle bathyal (Bandy and Arnal, 1957).

Pyrgo cf. P. murrhina (Schwager). Ecology: In addition to the two basal spines, specimens assigned to this group have 2-3 spines on each side of the basal spines.

Pyrgo rotalaria Loeblich and Tappan, 1953, Smithsonian Inst. Misc. Coll., Vol. 121, p. 47, pl. 6, figs. 5-6.

Pyrgo serrata (Bailey)-Biloculina serrata Bailey, 1861, Boston J. Nat. Hist., Vol. 7, p. 350, pl. 8, fig. E. Ecology: upper middle bathyal (Pflum and Frerichs, 1976).

Pyrgo williamsoni (Silvestri)-Biloculina williamsoni Silvestri, 1923, Accad. Pont. Rommana Nuovi Lincei, Vol. 76, p. 73, pl. 6, figs. 169-170., pl. 7, fig. 171.

Pyrulina fusiformis (Roemer)-Polymorphina (Globulinen) fusiformis Roemer, 1838, Neues Jahrb, Min. Geol. Petref-Kunde (Germany), p. 386 , pl. 3 , fig. $37 \mathrm{a}-\mathrm{b}$.

Quinqueloculina auberiana d'Orbigny, 1839, in de la Sagra, R. (Ed.), Histoire physique et naturelle de l'ile de Cuba (Vol. 8): Paris (Bertrand), p. 193, pl. 12, figs. 1-3.

Quinqueloculina compacta Serova, 1960, Voprosy Mikropal., no. 3, p. 93 , pl. 1, fig. 2 a-c.

Quinqueloculina lamarckiana d'Orbigny, 1839, in de la Sagra, R. (Ed.), Histoire physique et naturelle de l'ile de Cuba (Vol. 8): (Bertrand), p. 189, (plates published separately), pl. 11, figs. 14-15. Ecology: inner shelf (Ingle, 1980).

Quinqueloculina venusta Karrer, 1868, K. Akad. Wiss. Math.-Naturwiss. Kl., Sitzber, Bd. 58, Abt. 1, p. 147, pl. 2, fig. 6. This paper, Pl. 1, Fig. 6. Ecology: abyssal (Triloculina sp. of Burke, 1981). Woodruff (in press) finds this species in association with the mid- 
dle-late Miocene bottom water and the early Miocene bottom water.

Rectobolivina gasparensis Bermudez, 1949, Cushman Lab. Foram. Res. Spec. Publ., no. 25, p. 197, pl. 12, fig. 54.

Rectobolivina mexicana (Cushman)-Siphogenerina mexicana Cushman, 1926, U.S. Nat. Mus. Proc., Vol. 67, p. 15, pl. 5, fig. 4.

Recurvoides turbinatus (Bandy)-Haplophragmoides turbinatum Brady, 1881, Q. J., Microsc. Sci. London, n.s., Vol. 21, p. 50. Ecology: lower middle bathyal. Burke (1981) reports this species at depths of 1670 (rare) to $3057 \mathrm{~m}$, with highest abundances at $2660 \mathrm{~m}$. The shallow occurrences are associated with the deep oxygen-minimum zone which impinges on the Central American slope at lower middle bathyal depths. The more abundant deeper occurrences noted by Burke (1981) are associated with the deeper water masses (AABW, for example).

Reophax bilocularis Flint, 1899, U.S. Nat. Mus. Ann. Rept., Pt. 1, p. 273, pl. 17, fig. 2. Ecology: inner shelf (Loeblich and Tappan, 1953).

Reophax curtus Cushman, 1920, U.S. Nat. Mus. Bull., no. 104, p. 8, pl. 2, figs. 2-3. Ecology: inner shelf (Loeblich and Tappan, 1953; McDougall, 1982)

Reophax dentaliniformis (Brady) - Lituola (Reophax) dentaliformis Brady, 1881, Q. J. Microsc. Sci. London, n. s., Vol. 21, p. 49. Ecology: inner shelf (Loeblich and Tappan, 1953; McDougall, 1982).

Reophax scorpiurus Montfort, 1808, Conchyliologie systematique et classification methodique des coquilles (Vol. 1); (Schoell), pp. 330, 331. Ecology: inner shelf (Loeblich and Tappan, 1953; McDougall, 1982).

Reophax subfusiformis Earland, 1933, Discovery Repts. (England), Vol. 7, p. 74, pl. 2, figs. 16-19. Ecology: inner shelf (Loeblich and Tappan, 1953; McDougall, 1982).

Reusella pacifica Cushman and McCulloch, 1948, Allan Hancock Pacific Exped. Repts. (Vol. 6): Los Angeles (Univ. So. Calif.), p. 251, pl. 31, fig. 6. Ecology: inner shelf (Pflum and Frerichs, 1976).

Rosalina columbiensis (Cushman)-Discorbis columbiensis Cushman, 1925, Contr. Cushman Lab. Foram. Res., Vol. 1. p. 43, pl. 6, fig. 13. This paper, Pl. 5, Fig. 1. Ecology: outer shelf (Smith, 1964).

Rotorbinella lomaensis Bandy, 1953, J. Paleontol., Vol. 27, p. 179, pl. 22, fig. 6 .

Rotorbinella tholus (Galloway and Heminway)-Rotalia tholus Galloway and Heminway, 1941, N. Y. Acad. Sci., Sci. Survey Puerto Rico and Virgin Islands, Vol. 3, p. 382, pl. 20, fig. 2.

Rotorbinella versiformis Bandy, 1953, J. Paleontol., Vol. 27, p. 177, pl. 22 , fig. 5 .

Saracenaria acutauricularis (Fitchel and Moll)-Nautilus acutauricularis Fitchel and Moll, 1798, Microscopische und andere kleine Schalthiere aus den Geschlechtern Argonaute und Schiffer: Austria, p. 102, pl. 18, figs. g-i.

Saracenaria schencki Cushman and Hobson, 1935, Contr. Cushman Lab. Foram. Res., Vol. 11, p. 57, pl. 8, fig. 11.

Saracenaria senni Hedberg, 1937, J. Paleontol., Vol. 11, p. 674, pl. 90, fig. 18.

Schenckiella petrosa (Cushman and Bermudez)-Listerella petrosa Cushman and Bermudez, 1937, Contr. Cushman Lab. Foram. Res., Vol. 13, p. 5, pl. 1, figs. 24-26.

Schenckiella suteri Cushman and Stainforth, 1945, Cushman Lab. Foram. Res. Spec. Publ., no. 14, p. 19, pl. 2, fig. 26.

Sigmoilina schlumbergeri Silvestri, 1904, Mem. Accad. Pont. Romana Nuovi Lincei, Vol. 22, pp. 267, 269. Ecology: upper middle bathyal (Pflum and Frerichs, 1976).

Sigmoilina sigmoidea (Brady)-Planispirina sigmoidea Brady, 1884, Rept. Challenger Exped. (Zool.), Vol. 9, Pt. 22, p. 197, pl. 2, figs. $1-3$, p. 194 , tf. 5 c.

Sigmoilina tenuis (Czjzek)-Quinqueloculina tenuis Czjzek, $1848, \mathrm{Na}$ turwiss. Abh. (Austria), Bd. 2, Abt. 1, p. 149, pl. 13, figs. 31-34. This paper, Pl. 1, Fig. 7. Ecology: upper middle bathyal (Ingle, 1980).

Siphogenerina basispinata Cushman and Jarvis, 1929, Contr. Cushman Lab. Foram. Res., Vol. 5, p. 13, pl. 3, figs. 4-5. This paper. Pl. 4, Fig. 9. Ecology: upper middle bathyal (Ingle, 1980).

Siphogenerina multicostata Cushman and Jarvis, 1929, Contr. Cushman Lab. Foram. Res., Vol. 5. p. 14, pl. 3, fig. 6. This paper, Pl. 4, Fig. 11. Ecology: upper middle bathyal (Ingle, 1980).

Siphogenerina senni Cushman and Renz, 1941, Contr. Cushman Lab. Foram. Res., Vol. 17, p. 22, pl. 3, figs. 21-22.
Siphogenerina tenua Cushman and Kleinpell, 1934, Contr. Cushman Lab. Foram. Res., Vol. 10, p. 13, pl. 2, fig. 13.

Siphogenerina transversa Cushman-Siphogenerina raphanus (Parker and Jones) transversus Cushman, 1918, U.S. Nat. Mus. Bull., no. 103, p. 64, pl. 22, fig. 8. This paper, Pl. 4, Fig. 11. Ecology: upper middle bathyal (Ingle, 1980).

Siphonia pulchra Cushman, 1919, Carnegie Inst. Washington Publ., no. 291 , p. 42 , pl. 14, figs. 7 a-c. Ecology: outer shelf. This species is morphologically similar to $S$. bradyana, which has an upper depth limit in the outer shelf (Bandy, 1956; Phleger, 1960).

Siphonodosaria abyssorum (Brady)-Nodosaria abyssorum Brady. 1881, Q. J. Microsc. Sci. (England), n. s., Vol. 21, p. 63.

Siphonodosaria gracillima (Cushman and Jarvis)-Ellipsonodosaria nuttalli Cushman and Jarvis gracillima Cushman and Jarvis 1934, Contr. Cushman Lab. Foram. Res., Vol. 10. pl. 10, fig. 7.

Siphonodosaria paucistriata (Galloway and Morrey)-Nodosarella paucistriata Galloway and Morrey, 1929, Bull. Am. Paleontol., Vol. 15 , p. 42 , pl. 6 , fig. 12 .

Siphonodosaria verneuilla (d'Orbigny)-Dentalina verneuilla d'Orbigny, 1846, Die Fossilen Foraminiferen des Tertiaeren Beckens von Wien: (Gide et Comp.), p. 48, pl. 2, figs. 7-8.

Siphotextularia catenata (Cushman)-Textularia catenata Cushman, 1911, U.S. Nat. Mus. Bull., no. 71, p. 23, tf. 39-40.

Sphaeroidina bulloides d'Orbigny, 1826, Ann. Sci. Nat. (France), Ser. 1 , tome 7, p. 267 , modeles no. 65 . This paper, pl. 3, fig. 2. Ecology: upper middle bathyal (Ingle, 1980).

Spiroloculina texana Cushman and Ellisor, 1944, Contr. Cushman Lab. Foram. Res., Vol. 20, p. 51. pl. 8, figs. 14-15.

Stilostomella advena (Cushman and Laiming)-Nodogenerina advena Cushman and Laiming, 1931, J. Paleontol., Vol. 5, p. 106, pl. 11, fig. 19. Ecology: lower middle bathyal (Ingle, 1980).

Stilostomella adolphina (d'Orbigny)-Dentalina adolphina d'Orbigny, 1846, Die Fossilen Foraminiferen des Tertiaeren Beckens von Wien: (Gide et Comp.) p. 51. Ecology: lower middle bathyal (Ingle, 1980).

Stilostomella caribbaea Palmer and Bermudez, 1945, Bull. Am. Paleontol., Vol. 29, p. 53, pl. 1, fig. 6.

Stilostomella gracilis (Palmer and Bermudez)-Ellipsonodosaria gracilis Palmer and Bermudez, 1936, Mem. Soc. Cubana Hist. Nat., Vol. 10, p. 296, pl. 18, figs. 18-19. This paper, Pl. 3, Fig. 17.

Stilostomella lepidula (Schwager)-Nodosaria lepidula Schwager, 1866, Novara Exped. 1857-1859, Geol. Theil, Bd. 2, Abt. 2, p. 210, pl. 5, figs. 27-28. Ecology: lower middle bathyal (Ingle, 1980).

Stilostomella subspinosa (Cushman)-Ellipsonodosaria subspinosa Cushman, 1943, Contr. Cushman Lab. Foram. Res., Vol. 19, p. 92, pl. 16, figs. 6-7. This paper, Pl. 3, Fig. 16.

Suggrundia californica Kleinpell, 1938, Miocene Stratigraphy of California: Tulsa, Oklahoma (Am. Assoc. Pet. Geol.), p. 287, pl. 18, figs. 8-10. Ecology: upper bathyal, shallow oxygen-minimum zone (Ingle, 1980).

Suggrundia eckisi Natland, 1950, Mem. Geol. Am., no. 43, p. 23, pl. 9, fig. 12. This paper, Pl. 5, Fig. 12. Ecology: upper bathyal, shallow oxygen-minimum zone (Ingle, 1980; Ingle and Keller, 1980). Smith (1964) also notes that the length of this species decreases with increasing water depths.

Suggrundia kleinpelli Bramletti, 1951, in Woodring, W. P., and Bramlette, M. N., Prof. Pap. U.S. Geol. Surv, no. 222, p. 59, pl. 23, figs. 4-5, 9. Ecology: upper bathyal, shallow oxygen-minimum zone (Ingle, 1980).

Textularia agglutinanas d'Orbigny, 1839, in de la Sagra, R. (Ed.) Histoire physique et naturelle de l'ile de Cuba (Vol. 8): Paris (Bertrand), p. 144, pl. 1, figs. 17-18.

Textularia leuzingeri Cushman and Renz, 1941, Contr. Cushman Lab. Foram. Res., Vol. 17, p. 3, pl. 1, fig. 2.

Textularia panamensis Cushman, 1918, U.S. Nat. Mus. Bull., no. 103, p. 53, pl. 20, fig. 1. Ecology: inner shelf. This biofacies assignment is based on morphologic similarity of this species to $T$. schencki.

Textularia schencki Cushman and Valentine, 1930, Stanford Univ. Dept. Geol. Contr., Vol. 1. p. 8, pl. 1, fig. 3. Ecology: inner shelf (Golik and Phleger, 1977).

Trifarina angulosa (Williamson)-Uvigerina angulosa Williamson, $1858, R$. Soc. (England), p. 67, pl. 5, fig. 140. Ecology: outer shelf (Ingle, 1980).

Trifarina bradyi Cushman, 1923, U.S. Nat. Mus. Bull., no. 104, p. 99, pl. 22 , figs. $3 a-b, 4 a-b, 5-8$, and $9 a-b$. 
Trifarina carinata (Cushman)-Angulogerina carinata Cushman, 1927, Scripps Inst. Oceanogr. Tech. Ser., Vol. 1, p. 159, pl. 4, fig. 3. Ecology: upper bathyal (Smith, 1964; Ingle, 1980; Resig, 1981).

Trifarina hannai (Beck)-Angulogerina hannai Beck, 1943, J. Paleontol., Vol. 17. pp. 607-607, pl. 108, figs. 26, 28.

Trifarina occidentalis (Cushman)-Uvigerina occidentalis Cushman, 1923, U.S. Nat. Mus. Bull., no. 104, p. 169. Ecology: outer shelf to upper bathyal (Ingle, 1980).

Triloculina globosa (Hanna and Hanna)-Quinqueloculina globosa Hanna and Hanna, 1924, Washington Univ. Publ. Geol., Vol. 1, p. 58, pl. 13 , figs. $1-2$.

Triloculina oblongata (Montagu) -Vermiculum oblongum Montagu, 1803, Testacea Britannica: (Hollis), p. 522, pl. 14, fig. 9.

Triloculina trihedra Loeblich and Tappan, 1953, Smithsonian Inst. Misc. Coll., Vol. 121, p. 45, pl. 4, fig. 10. This paper, Pl. 1 Fig. 5. Ecology: lower middle bathyal. Although Loeblich and Tappan (1953) associate this species with neritic depths in the Arctic Ocean, Burke (1981) and Woodruff (in press) associate this form (Triloculina sp. B of Burke, 1981; Triloculina sp. of Woodruff, in press) with deep oxygen-minimum zone and deeper water masses in the central Pacific.

Tritaxilina colei Cushman and Seigfus, 1935, Contr. Cushman Lab. Foram. Res., Vol. 11, p. 92, pl. 14, figs. 5-6.

Tritaxilina mexicana Cushman, 1925, Contr. Cushman Lab. Foram. Res., Vol. 1. p. 64, pl. 10, fig. 4.

Uvigerina baggi Galloway and Wissler, 1927, J. Paleontol., Vol. 1. p. 75, pl. 11, fig. 19. Ecology: outer shelf to upper bathyal (Trifarina baggi of Ingle, 1980).

Uvigerina carapitana Hedberg, 1937, J. Paleontol., Vol. 11, p. 677, pl. 91, fig. 20.

Uvigerina excellens Todd, 1948, in Cushman, J. A., and McCulloch, I., Allan Hancock Pacific Exped. (Vol. 6): Los Angeles (Univ. So. Calif.), p. 258, pl. 33, fig. 2. Ecology: upper bathyal (Smith, 1964).

Uvigerina gallowayi Cushman, 1929, Contr. Cushman Lab. Foram. Res., Vol. 5. p. 94, pl. 13, figs. 33-34. Ecology: upper bathyal (Ingle, 1980).

Uvigerina gallowayi basicordata Cushman and Renz-Uvigerina gallowayi Cushman basicordata Cushman and Renz, 1941, Contr. Cushman Lab. Foram. Res., Vol. 17, p. 21. pl. 3, fig. 18.

Uvigerina hispida Schwager, 1866, Novara Exped. 1857-1859, Geol. Theil, Bd. 2, Abt. 2, p. 249, pl. 7, fig. 95. This paper, Pl. 4, Fig. 5. Ecology: lower middle bathyal (Ingle, 1980; Ingle and Keller. 1980).

Uvigerina hispidocostata Cushman and Todd, 1945, Cushman Lab. Foram. Res. Spec. Publ., no. 15, p. 51, pl. 7, figs. 27, 31. Ecology: upper middle bathyal (Ingle, 1980).

Uvigerina hootsi Rankin, 1934, in Cushman, J. A., and Kleinpell, R. M., Contr. Cushman Lab. Foram. Res., Vol. 10, p. 22, pl. 3, figs. 8-9. Ecology: upper middle bathyal (Ingle, 1980).

Uvigerina incilis Todd, 1948, in Cushman, J. A., and McCulloch, I., Allan Hancock Pacific Exped. (Vol, 6): Los Angeles (Univ. So. Calif.), p. 260, pl. 33, fig. 4. Ecology: outer shelf (Smith, 1964).

Uvigerina juncea Cushman and Todd, 1941, Contr. Cushman Lab. Foram. Res., Vol. 17, p. 78, pl. 20, figs. 4-11. Ecology: outer shelf to upper bathyal (Ingle, 1980).

Uvigerina peregrina Cushman, 1923, U.S. Nat. Mus. Bull., no. 104, p. 166, pl. 42, figs. 7-10. Ecology: upper bathyal (Ingle, 1980).
The upper depth limit of this species has been noted at a variety of depths along the East Pacific Margin (Smith, 1964; Ingle and Keller, 1980).

Uvigerina peregrina dirupta Todd, 1948, in Cushman, J. A., and McCulloch, I., Allan Hancock Pacific Exped. (Vol. 6): Los Angeles (Univ. So. Calif.), p. 267, pl. 34, fig. 3. Ecology: upper middle bathyal (Ingle, 1980; Ingle and Keller, 1980).

Uvigerina rustica Cushman and Edwards, 1938, Contr. Cushman Lab. Foram. Res., Vol. 14, p. 83, pl. 14, fig. 6. Ecology: lower middle bathyal (Pflum and Frerichs, 1976).

Uvigerina semitrigonia Galloway and Wissler, 1927, J. Paleontol., Vol. 1, p. 77, pl. 11, fig. 21. Ecology: outer shelf (Angulogerina semitrigonia of Smith, 1964).

Uvigerina senticosa Cushman, 1927, Scripps Inst. Oceanogr. Tech. Ser., Vol. 1, p. 159, pl. 3, fig. 14. Ecology: lower bathyal (Ingle, 1964).

Uvigerina seqeundoensis Cushman and Galliher, 1934, Contr. Cushman Lab. Foram. Res., Vol. 10, p. 26, pl. 4, fig. 11.

Uvigerina striata d'Orbigny, 1839, Voyage dans l'Amerique Meridionale: Foraminiferes (Vol. 5): p. 53, pl. 7, fig. 16. Ecology: upper bathyal (Resig, 1981).

Uvigerina vaderescens Cushman-Uvigerina probiscidea Schwager vaderescens Cushman, 1933, Contr, Cushman Lab. Foram. Res., Vol. 9, p. 85, pl. 8, figs. 14-15.

Vaginulina americana Cushman, 1923, U. S Nat. Mus. Bull., no. 104, p. 135 , pl. 38 , figs. 3-4.

Vaginulinopsis nudicostata (Cushman and Hanna)-Cristellaria mexicana Cushman subspecies nudicostata Cushman and G. D. Hanna, 1927, p. 216, pl. 14, fig. 2.

Vaginulinopsis saundersi (Hanna and Hanna)-Cristellaria saundersi Hanna and Hanna, 1924, Wash. Univ. (Seattle) Publ. Geol., Vol. 1 , p. 61 , pl. 13 , figs. 5-6.

Valvulineria araucana (d'Orbigny)-Rosalina araucana d'Orbigny, 1839, Voyage dans l'Amerique Meridionale: Foraminiferes (Vol. 5): p. 44, pl. 6, figs. 16-18. Ecology: upper middle bathyal (Ingle, 1980).

Valvulineria glabra Cushman-Valvulineria vilardeboana (d'Orbigny) glabra Cushman, 1927, Scripps Inst. Oceanogr. Tech. Ser., Vol. 1, p. 161, pl. 4, figs. 5-6. This paper, P1. 5, Fig. 4. Ecology: upper middle bathyal (Smith, 1964).

Valvulineria inaequalis (d'Orbigny) - Valvulina inaequalis d'Orbigny, 1839, Voyage dans l'Amerique Meridionale: Foraminiferes (Vol. 5): Strasbourg, France (Levrault), p. 48, pl. 7, figs. 10-12. This paper, Pl. 5, Fig. 5. Ecology: outer shelf (Uchio, 1960).

Valvulineria malagaensis Kleinpell, 1938, Miocene Stratigraphy of California: (Am. Assoc. Pet. Geol.), p. 308, pl. 22, figs. 10-12. Ecology: upper middle bathyal (Ingle, 1980).

Valvulineria minuta (Schubert)-Discorbina rugosa (d'Orbigny) minuta Schubert, 1904, Geol. Reichsanst. Jahrb. (Austria), Bd. 53, Heft 3, p. 420 .

Valvulineria venezuelana Hedberg, 1937, J. Paleontol., Vol. 11, p. 678, pl. 91 , fig. 21.

Valvulineria vilardeboana (d'Orbigny)-Rosalina vilardeboana d'Orbigny. 1939. Voyage dans l'Amerique Meridionale: Foraminifères (Vol. 5): Strasbourg, France (Levrault), p. 44, pl. 6, figs. 13-15. Ecology: upper middle bathyal (Smith, 1964).

Vulvulina spinosa Cushman, 1927, Contr. Cushman Lab. Foram. Res., Vol. 3, p. 111, pl. 23. fig. 1. This paper, Pl. 1, Fig. 2. 


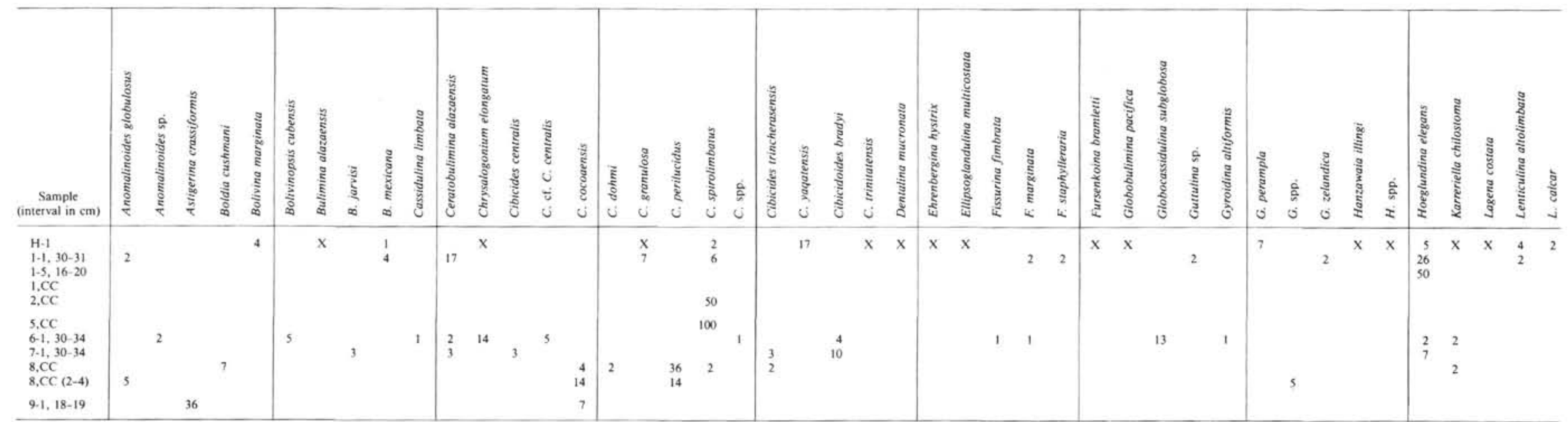

Note: Benthic foraminiferal oceurrences are given as percent of the total fauna, and $\mathrm{X}=$ less than $1 \%$

Table 4. (Continued).

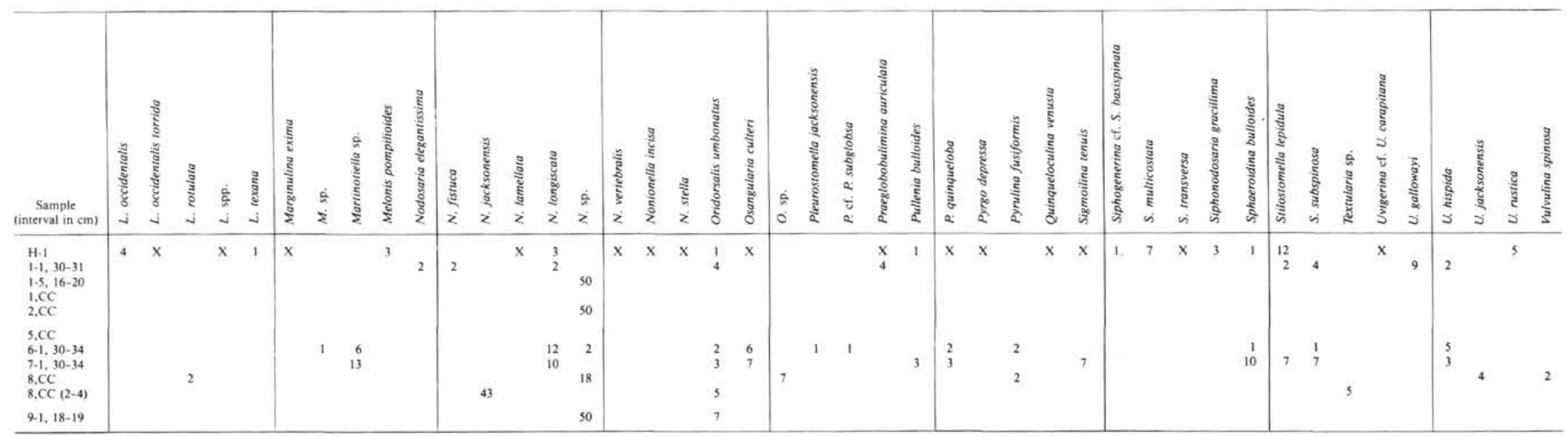


Table 5. Faunal distribution, Site 566.

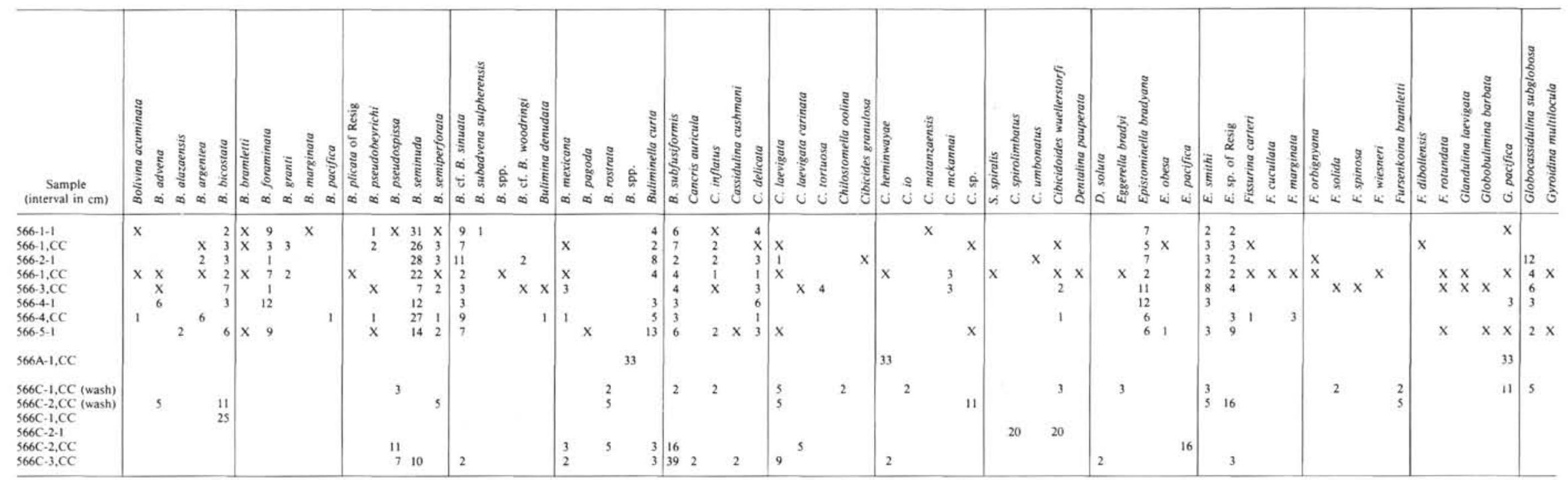

Note: Benthic foraminiferal occurrences are given as percent of the total fauna, and $X=$ less than $1 \%$. Biofacies abundances are also given in percent of the total fauna.

Table 5. (Continued).

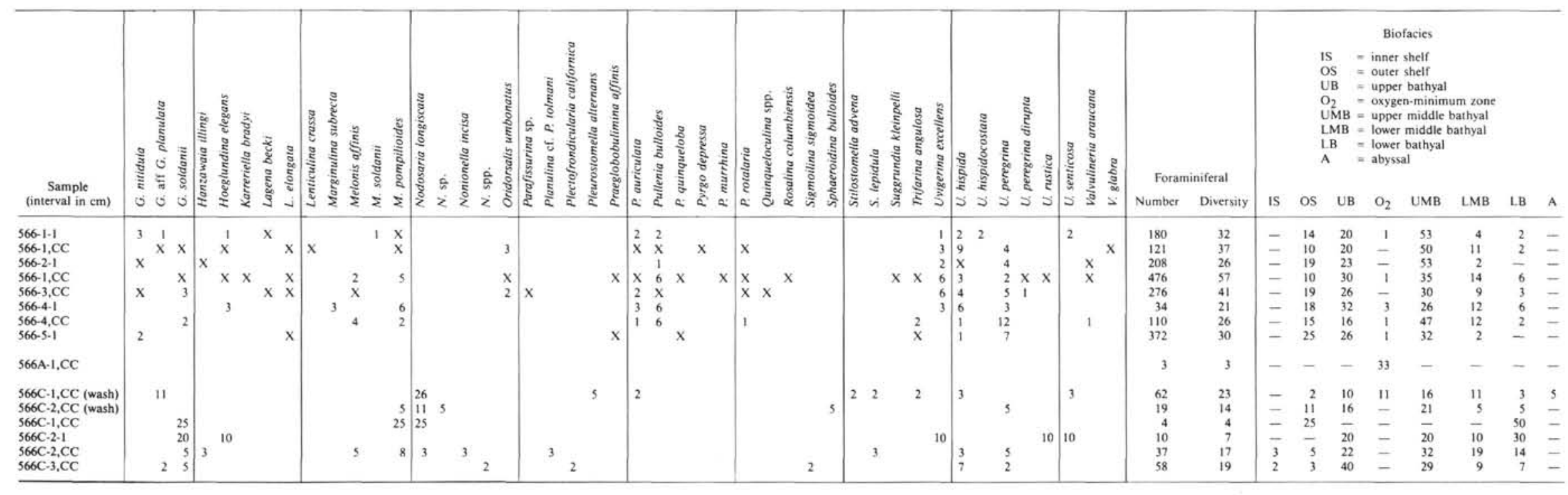


Table 6. Faunal distribution, Site 567.

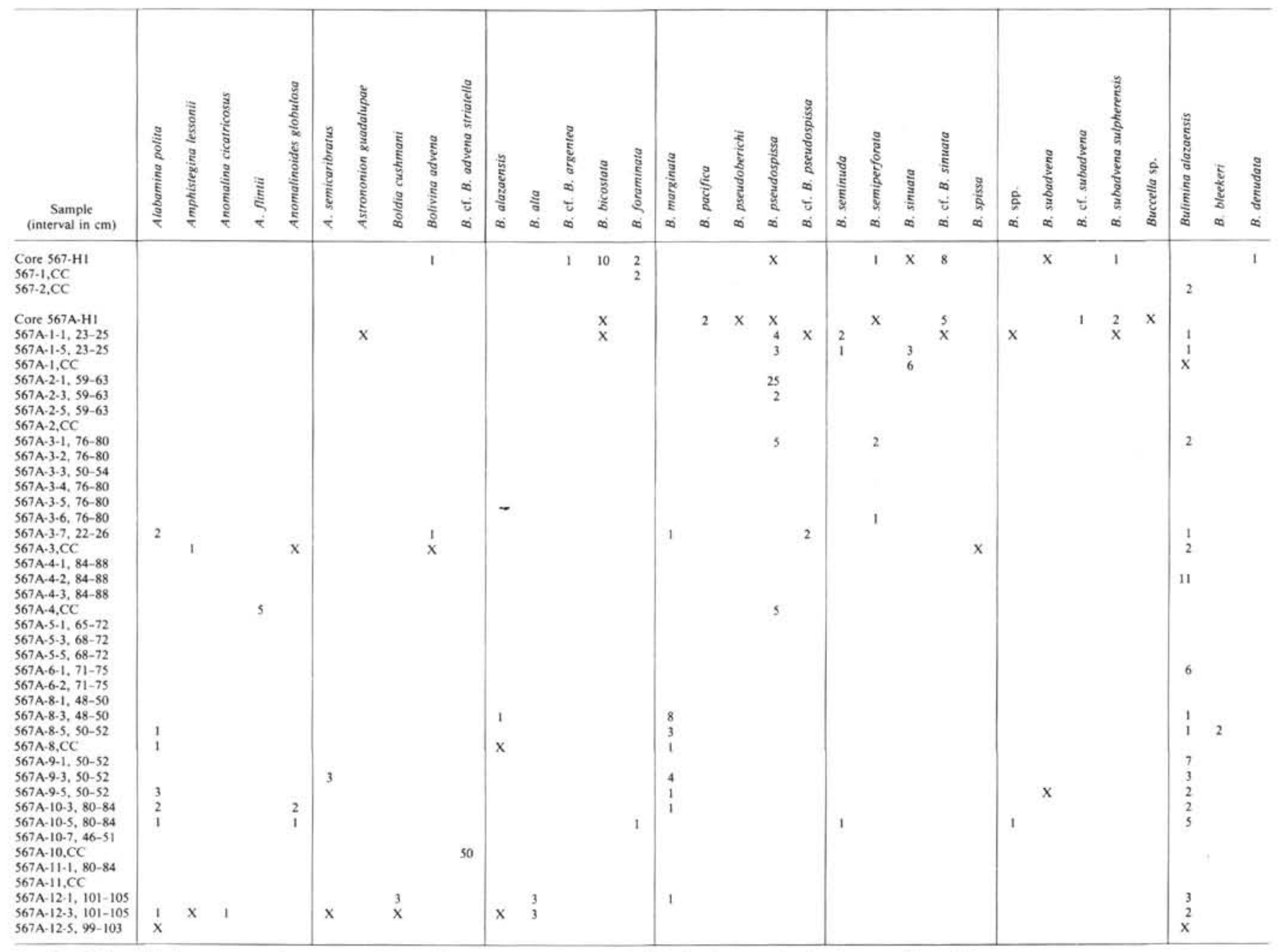

Note: Benthic foraminiferal occurrences are given as percent of the total fauna, and $\mathrm{X}=$ less than $1 \%$. Biofacies abundances are also given in percent of the total fauna. 
Table 6. (Continued).

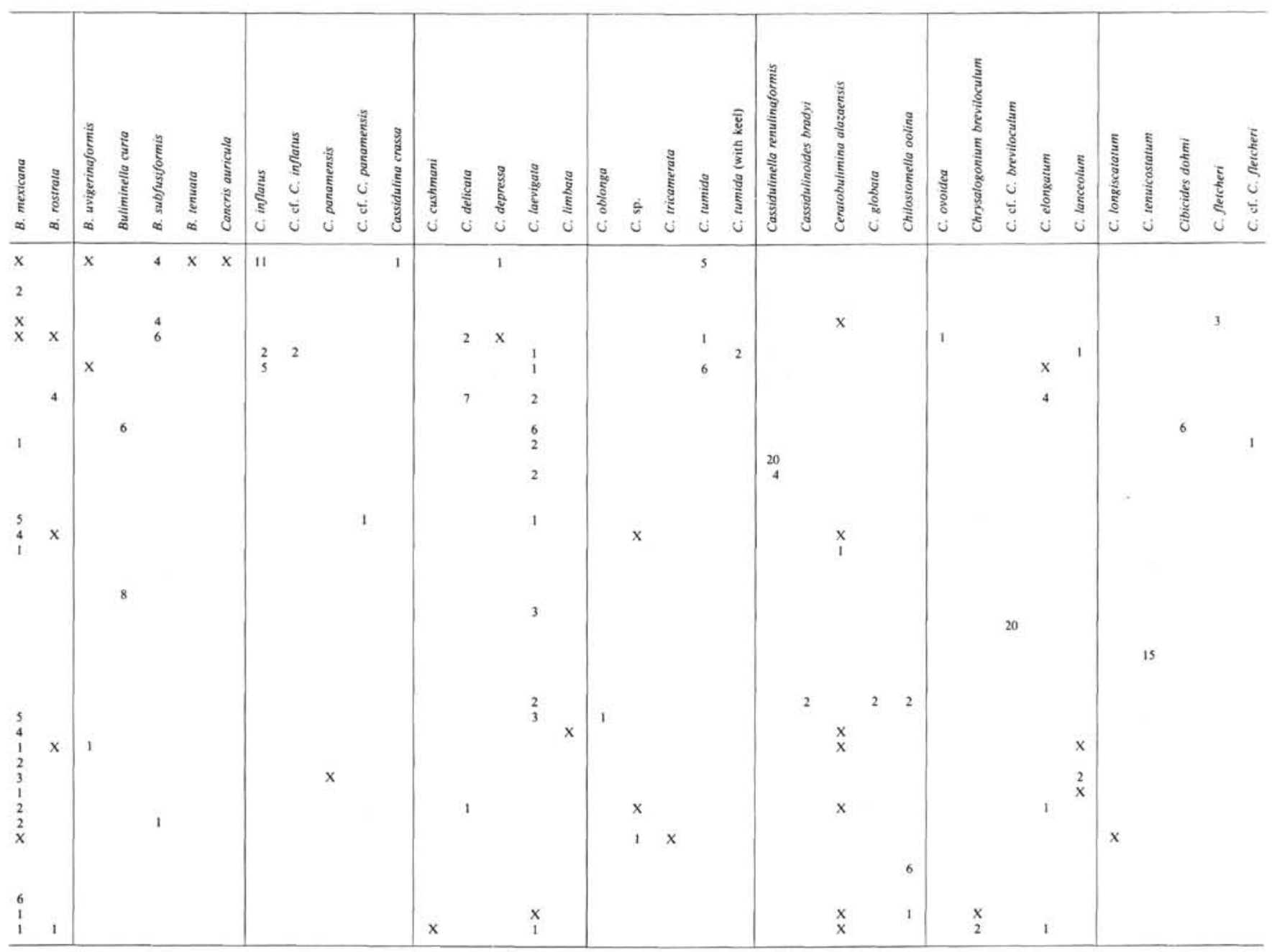


Table 6. (Continued).

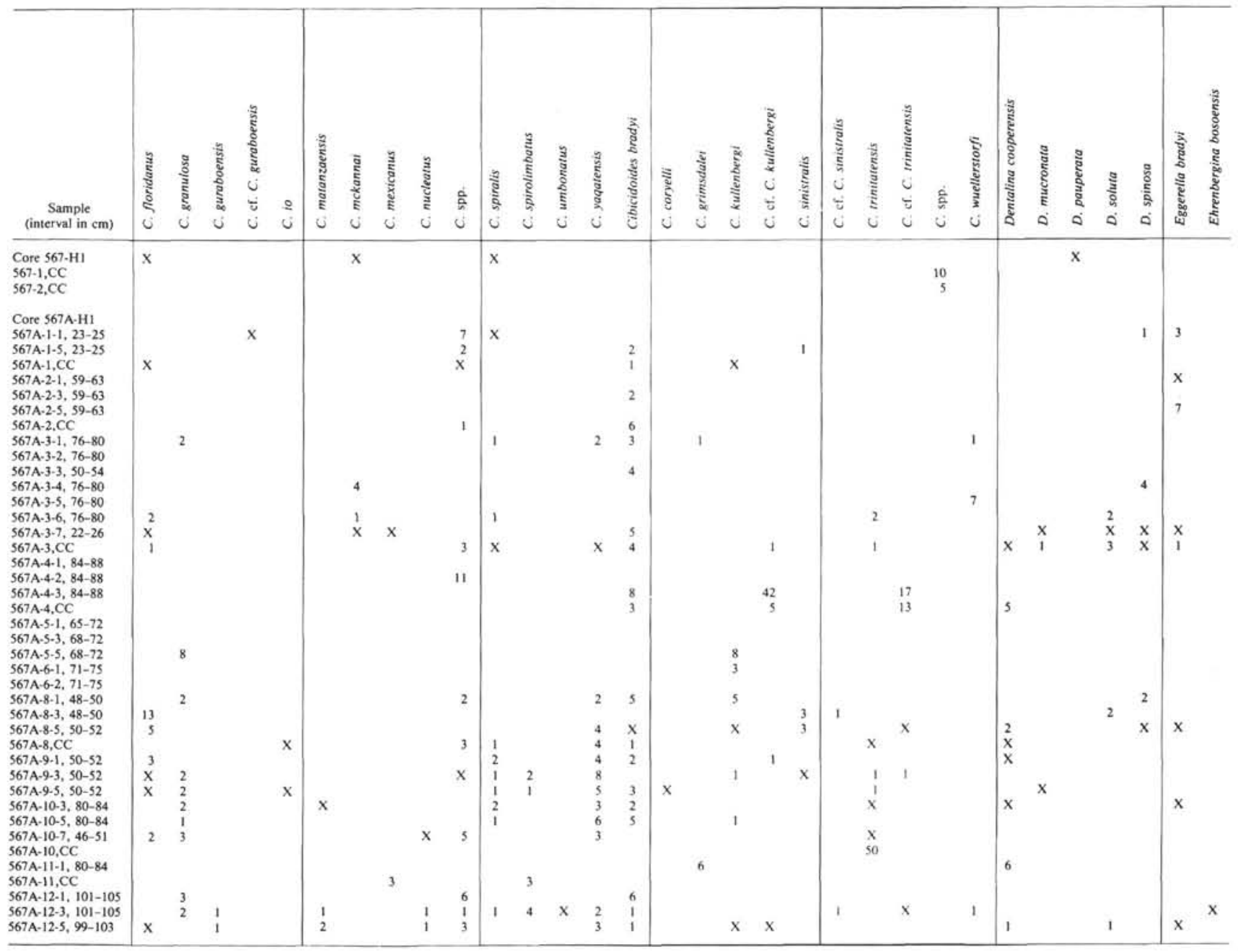


Table 6. (Continued).

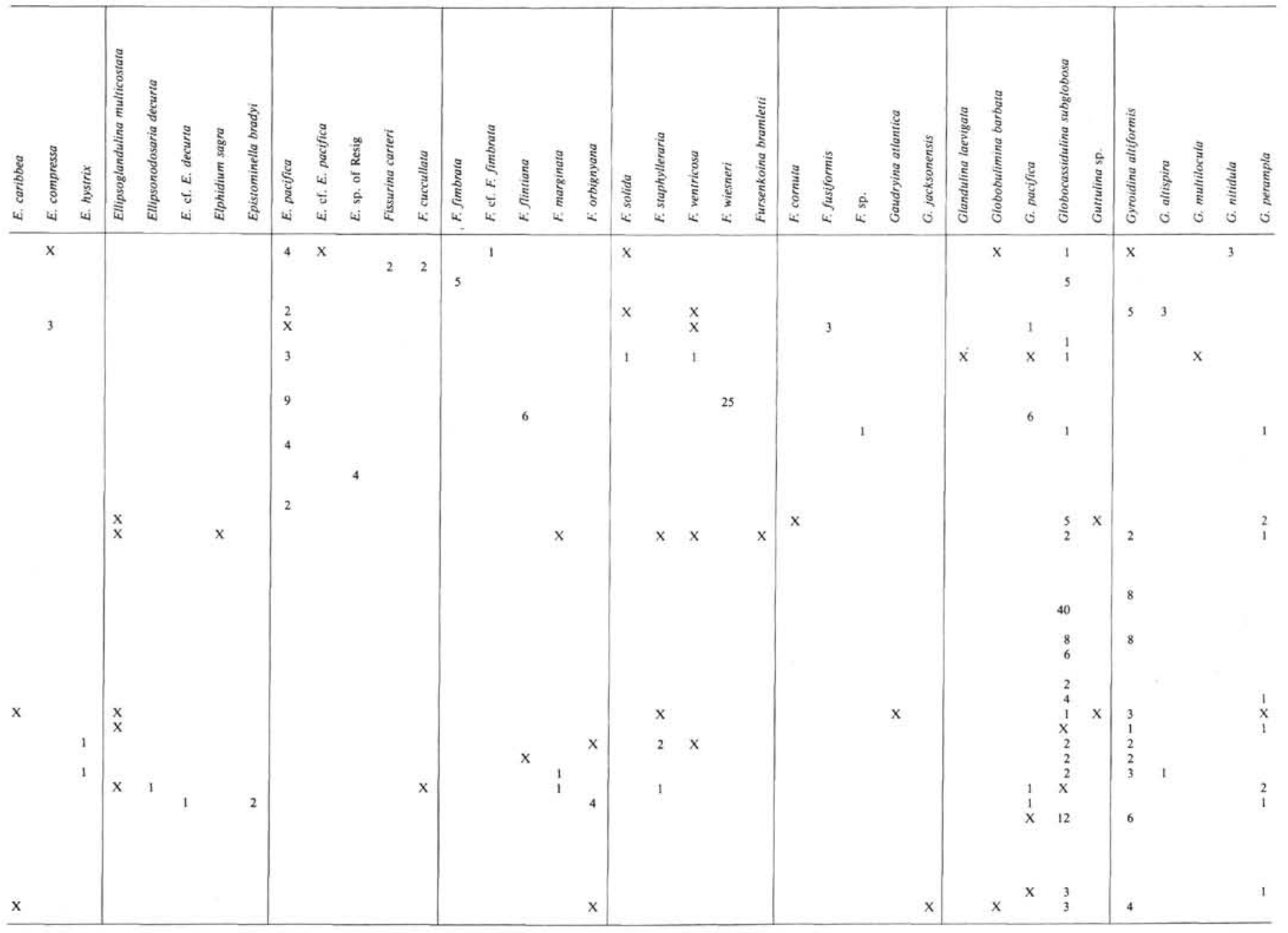


Table 6. (Continued).

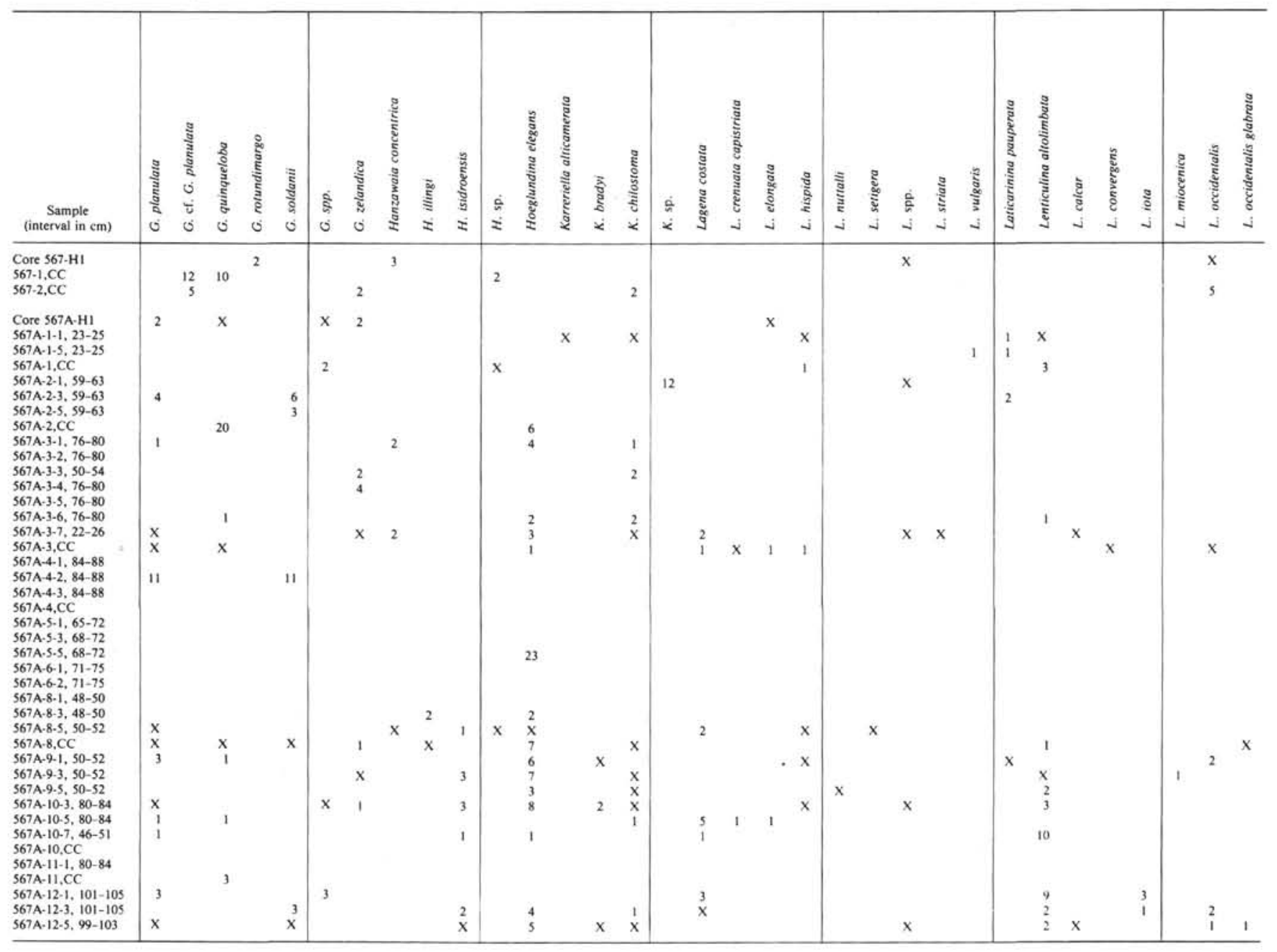


Table 6. (Continued).

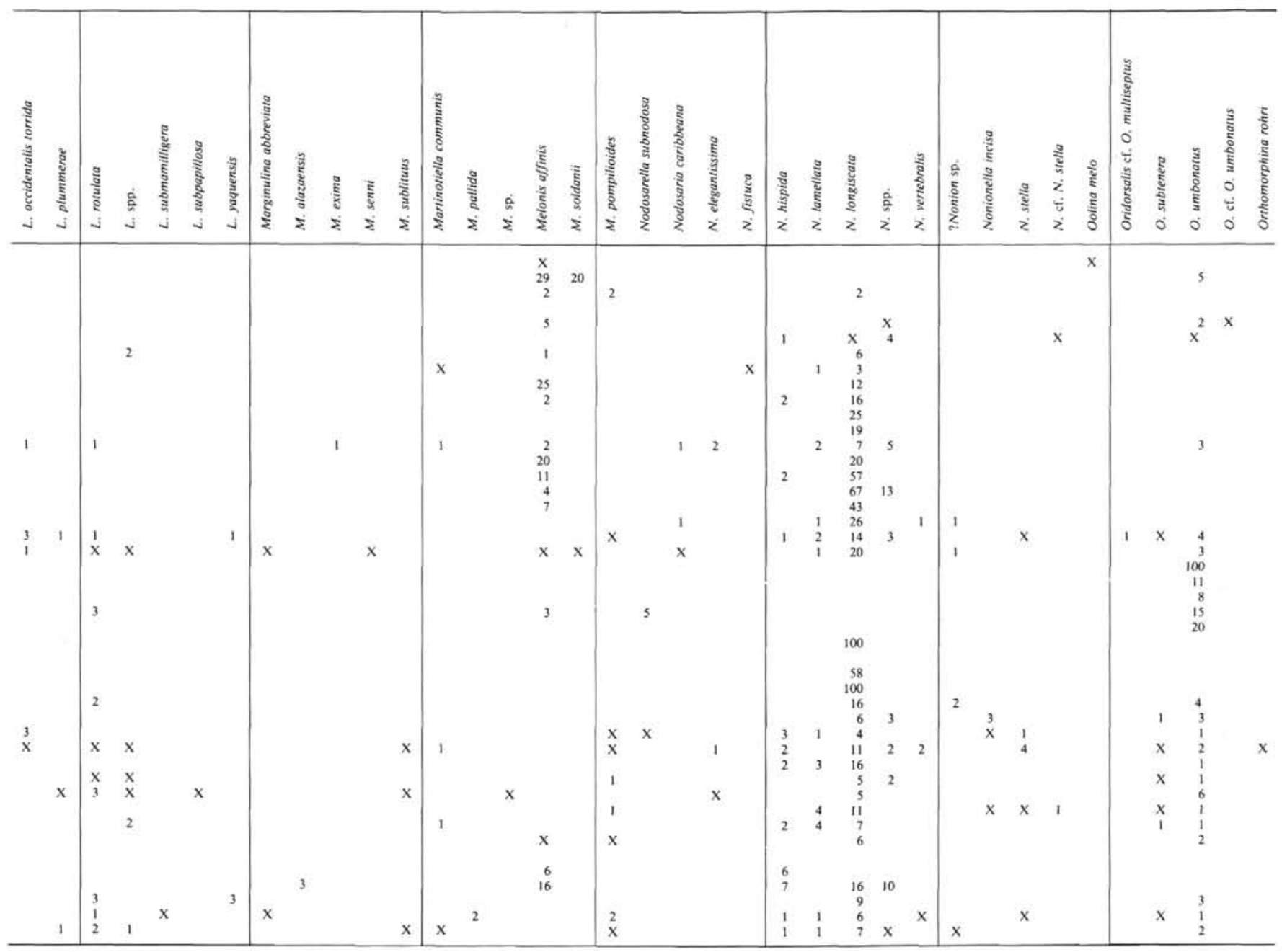


Table 6. (Continued).

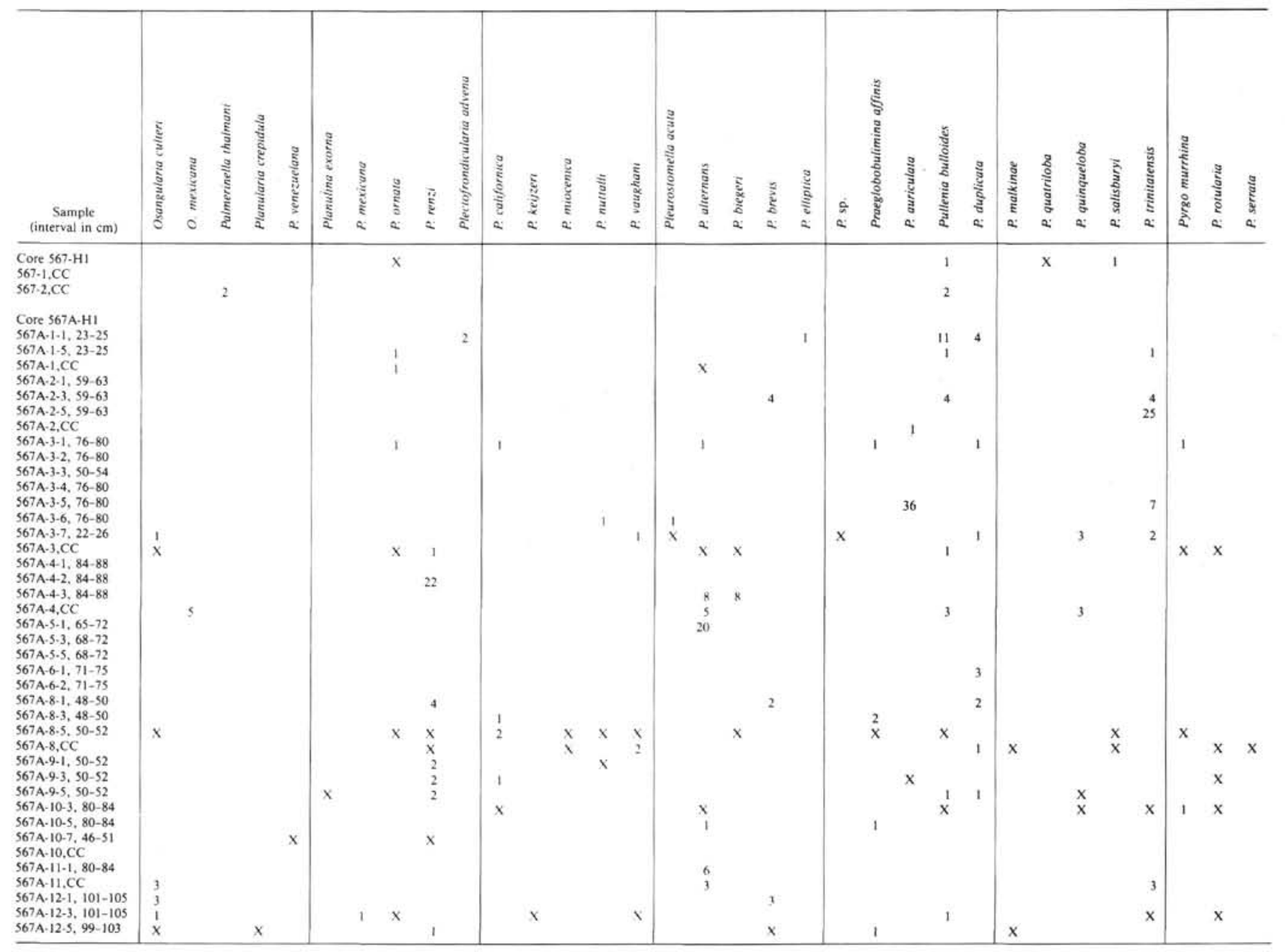


Table 6. (Continued).

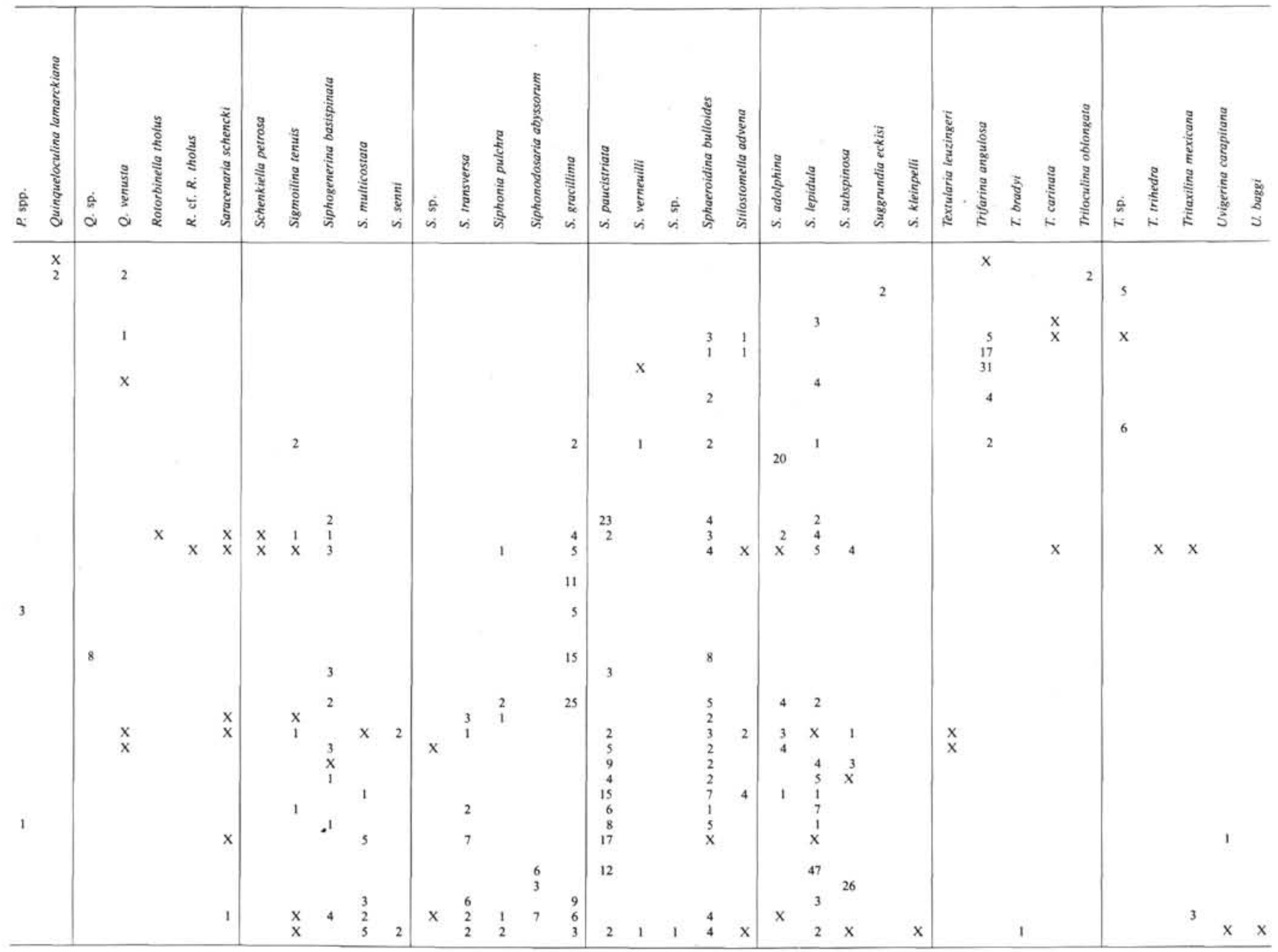


Table 6. (Continued).

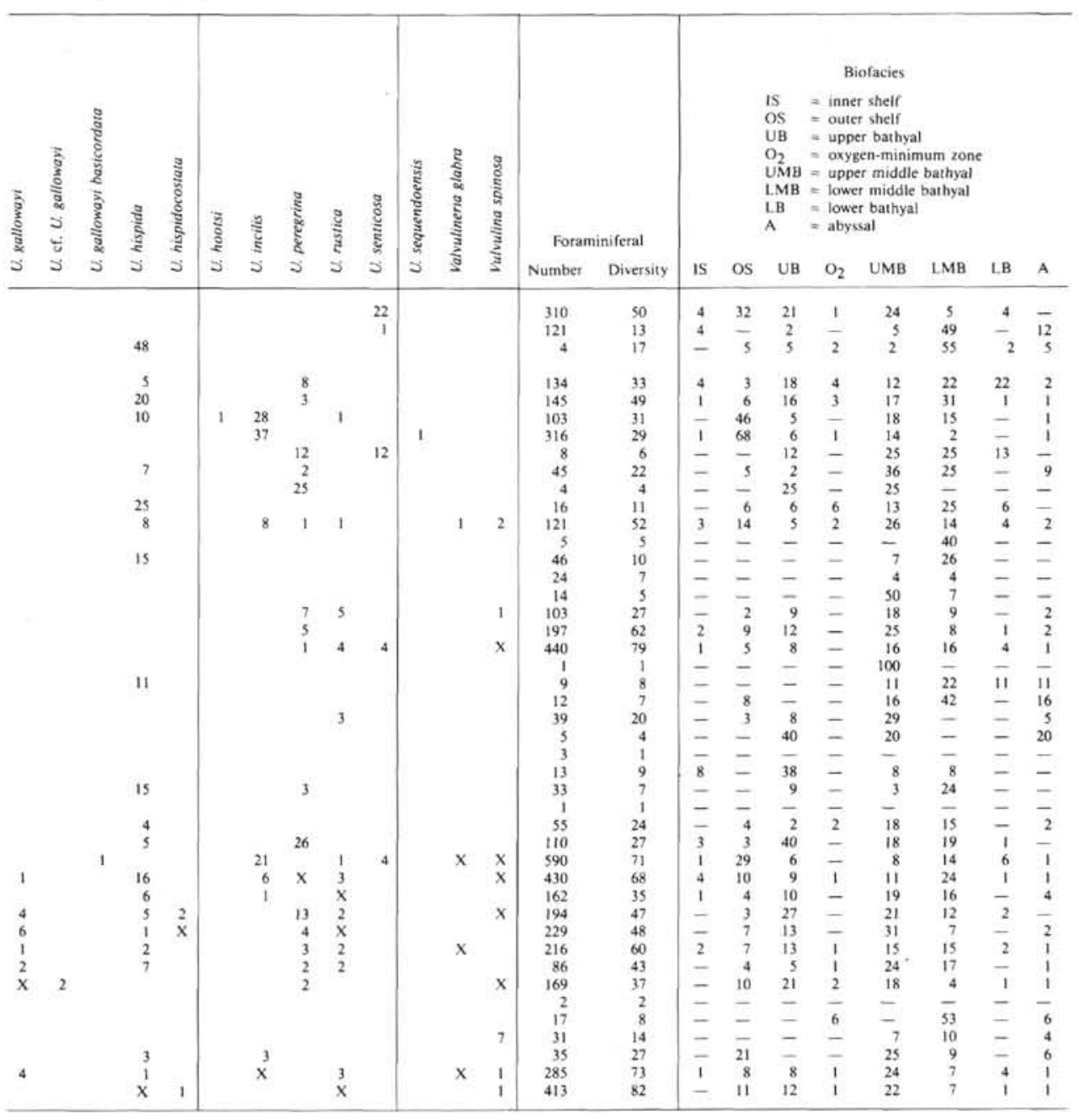


Table 7. Samples barren of benthic foraminifers, Leg 84.

\begin{tabular}{|c|c|}
\hline Site 566 & Site 569 (Hole 569) (Cont.) \\
\hline $566-5, \mathrm{CC}$ & $569-16-1,98-102$ \\
\hline $566-6, \mathrm{CC}$ & $569-17-1,47-51$ \\
\hline $566-6-1,46-50$ & $569-24-1,30-34$ \\
\hline $566-7, \mathrm{CC}$ & $569-24, \mathrm{CC}$ \\
\hline $566-8, \mathrm{CC}$ & $\begin{array}{l}569-25-3,20-24 \\
569-25, \mathrm{CC}\end{array}$ \\
\hline Site 567 & $569-26, \mathrm{CC}$ \\
\hline $\begin{array}{l}567-6-3,71-75 \\
567-6-5,34-35\end{array}$ & Site 569 (Hole 569A) \\
\hline $567-6, \mathrm{CC}$ & $569 A-2-1,25-29$ \\
\hline $567-7-1,50-52$ & $569 \mathrm{~A}-4, \mathrm{CC}$ \\
\hline $567-7, \mathrm{CC}$ & $\begin{array}{l}569 A-6, C C \\
569 A-7, C C\end{array}$ \\
\hline Site 568 & $\begin{array}{l}569 \mathrm{~A}-9, \mathrm{CC} \\
569 \mathrm{~A}-10-1,0-5\end{array}$ \\
\hline $\begin{array}{l}568-22-5,32-36 \\
568-23-1,92-96\end{array}$ & \\
\hline $\begin{array}{l}568-23-3,92-96 \\
568-24-1,120-134\end{array}$ & Site 570 \\
\hline $568-24-6,130-134$ & $570-36-2,48-50$ \\
\hline $568-25-6,51-55$ & $\begin{array}{l}570-36, C C \\
570-37-1,88-90\end{array}$ \\
\hline Site 569 (Hole 569) & $\begin{array}{l}570-37-1,28-30 \\
570-37, C C\end{array}$ \\
\hline $569-8, \mathrm{CC}$ & $570-38-1,55-57$ \\
\hline $569-9, \mathrm{CC}$ & $570-38, \mathrm{CC}$ \\
\hline $569-12-3,20-24$ & $570-39-1,70-76$ \\
\hline $\begin{array}{l}569-12-5,20-24 \\
569-15-1,104-108\end{array}$ & $570-39, \mathrm{CC}$ \\
\hline
\end{tabular}

Note: Sample intervals in $\mathrm{cm}$. 


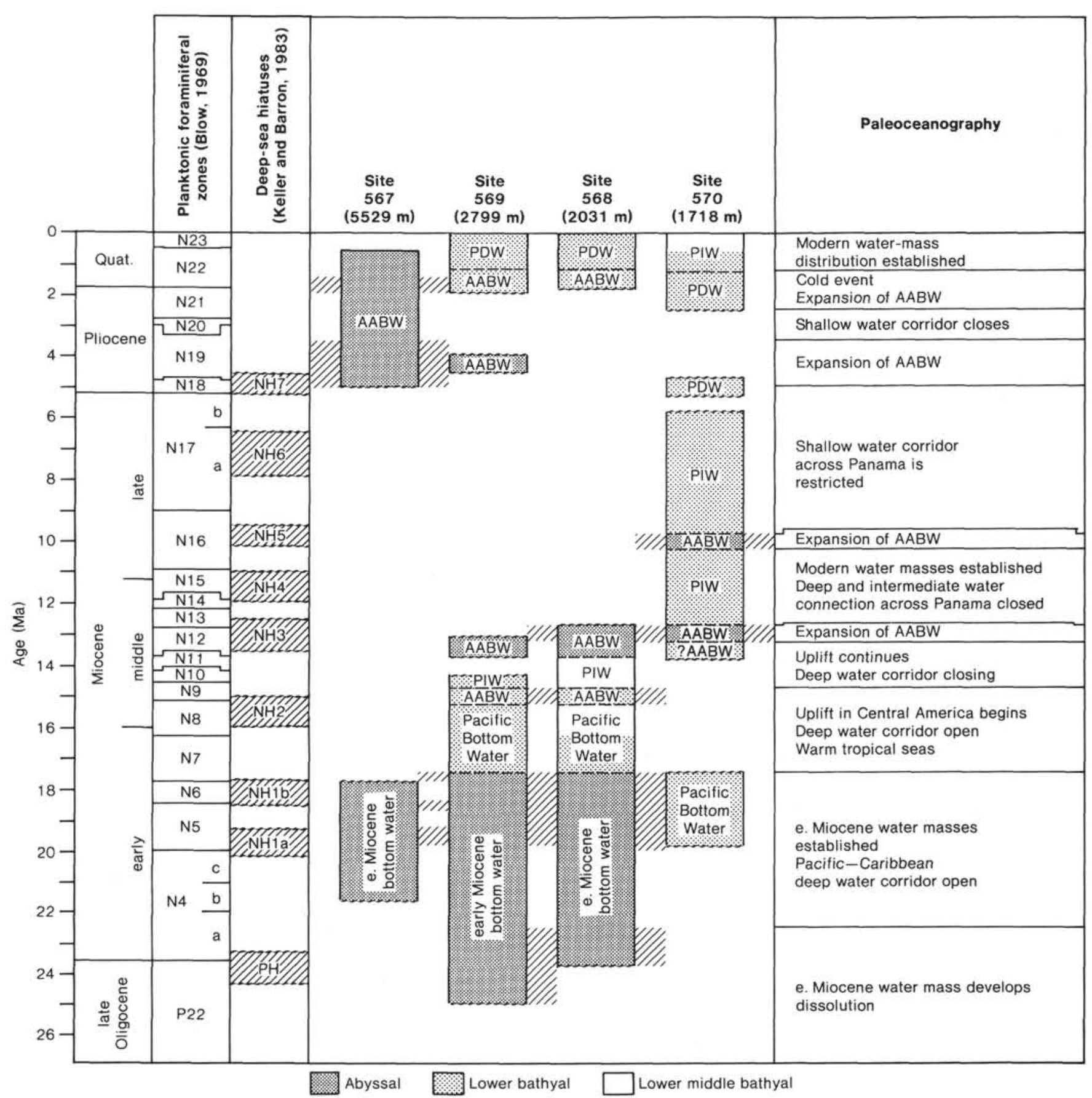

Figure 8. Biofacies, water mass, and paleoceanographic interpretations of DSDP Leg 84 sites. DSDP Leg 84 sites and the deep-sea hiatuses of Keller and Barron (1983) are plotted against the planktonic time scale as in Figure 3. Biofacies and water masses which were interpreted from the benthic foraminiferal analysis are shown in each of the site columns. Dissolution intervals are indicated by hachure lines. Events related to paleoceanography are summarized in the last column and discussed in the text. 


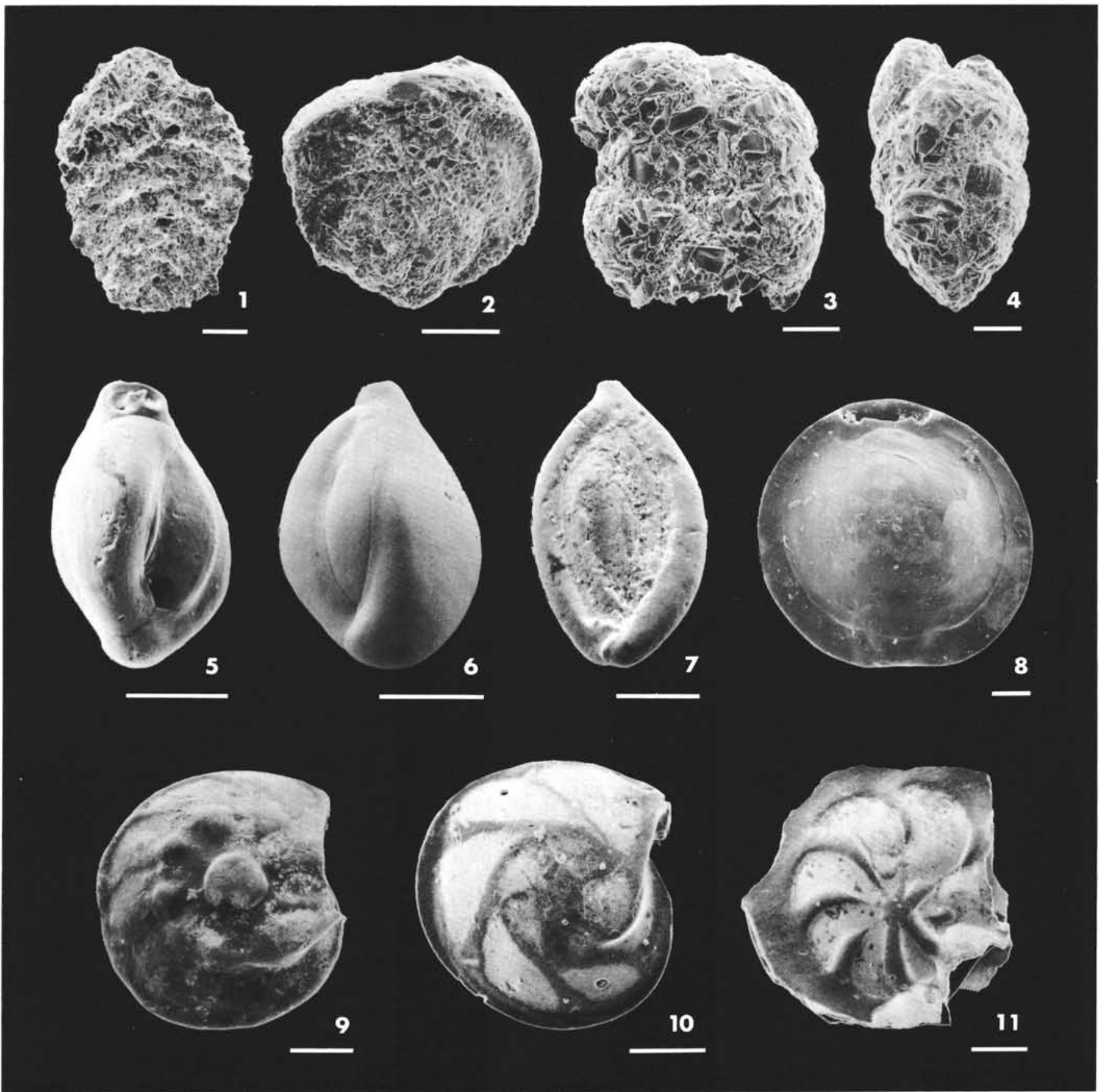

Plate 1. (Scale bars $=100 \mu \mathrm{m}$.) 1. Textularia leuzingeri Cushman and Renz. Sample 568-35-5, 97-99 cm. 2, 9. Sample 568-38-1, 80-85 cm, (2) Vulvulina spinosa Cushman, (9) Lenticulina caritae Bermudez. 3-4. Sample 568-2-1, 80-84 cm, (3) Alveolophragmium crassimargo (Norman), (4) Karreriella bradyi (Cushman). 5, 7, 10-11. Sample 568-41-3, 123-127 cm, (5) Triloculina trihedra Loeblich and Tappan, (7) Sigmoilina tenuis (Czjzek), (10) Lenticulina dicampyla (Franzenau), (11) Lenticulina iota (Cushman). 6. Quinqueloculina venusta Karrer, Sample 570-1,CC. 8. Pyrgo depressa (d'Orbigny), Sample 570-4-1, 40-44 cm. 


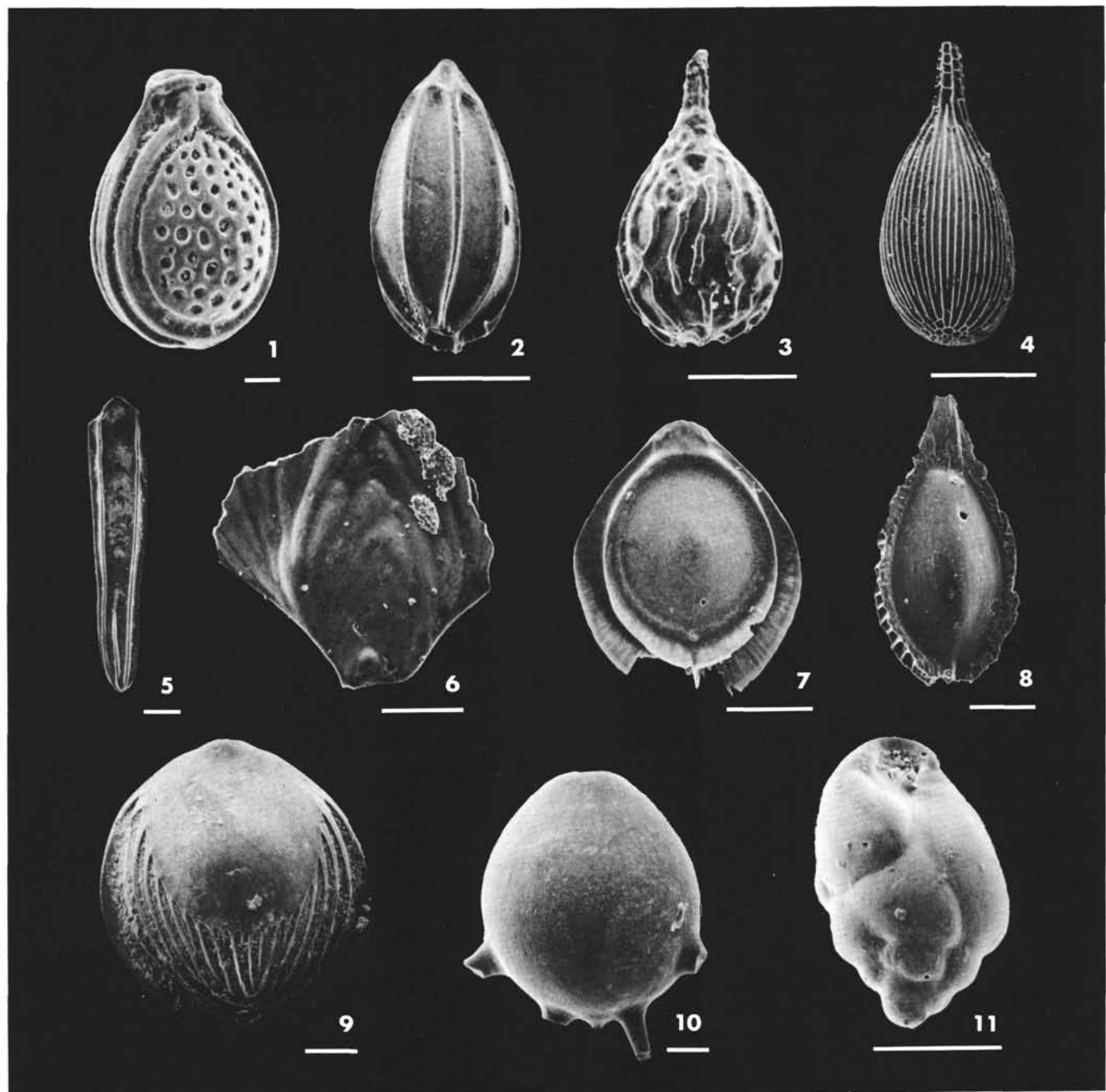

Plate 2. (Scale bars $=100 \mu \mathrm{m}$ unless otherwise indicated.) 1, 3, 10. Sample 570-5,CC, (1) Lagena castrensis Schwager, bar $=30 \mu \mathrm{m},(3)$ Lagena sp., (10) Fissurina staphylleraria Schwager. 2, 4, 8-9, 11. Sample 570-4-1, 40-44 cm, (2) Lagena costata (Williamson), (4)Lagena striata (d'Orbigny), (8) Fissurina subformosa Parr, (9) Fissurina cf. F. kugleri (Cushman and Stainforth), (11) Buliminella curta Cushman, bar $=3 \mu \mathrm{m} .55$. Plectofrondicularia californica Cushman and Stewart, Sample 568-39-3, 84-88 cm. 6. Plectofrondicularia vaughani Cushman, Sample 568-41-3, $123-127 \mathrm{~cm}$. 7. Fissurina alveolata (Brady), Sample 568-2-1, 80-84 cm. 

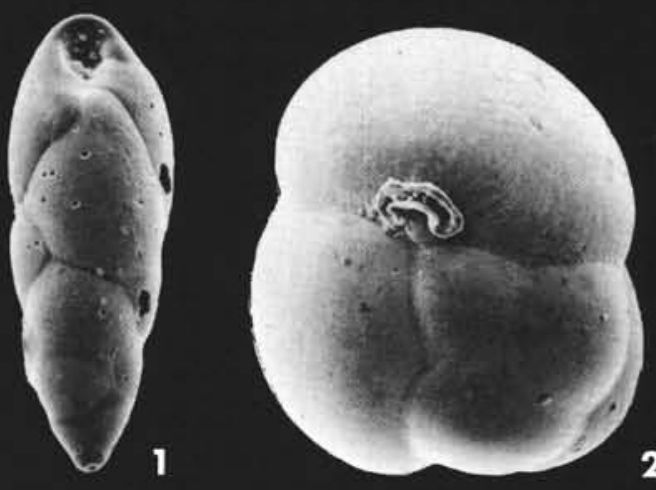

2

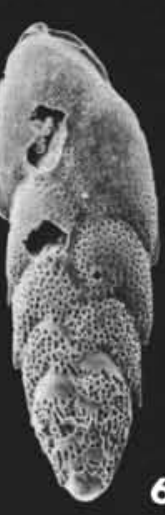

6
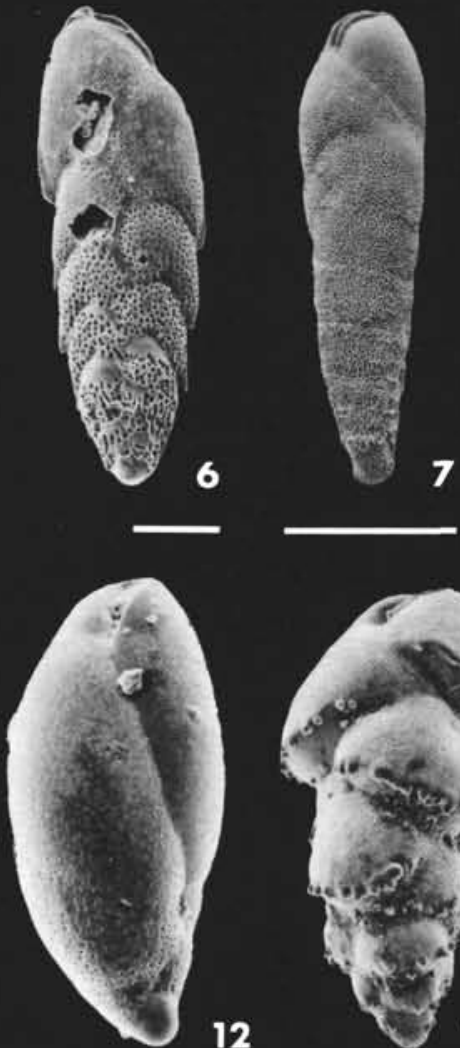

12
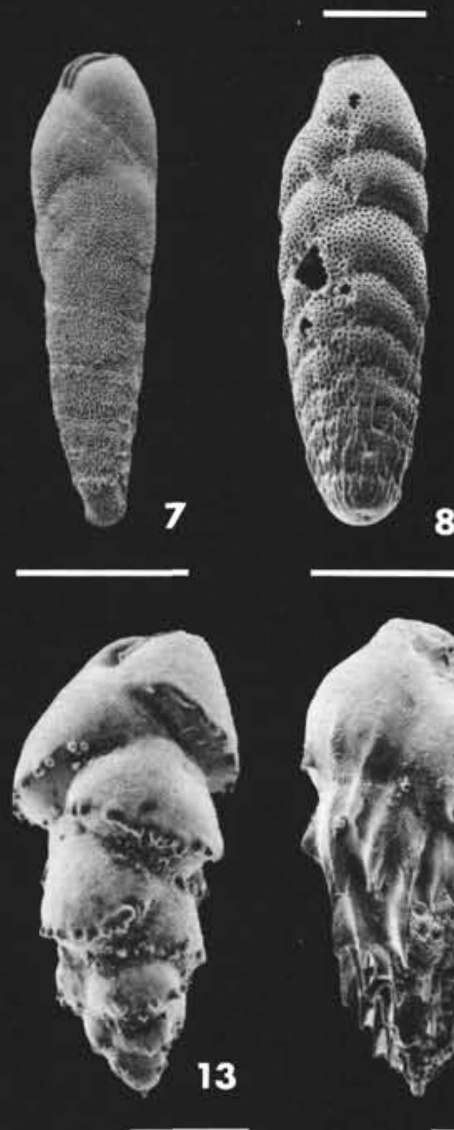
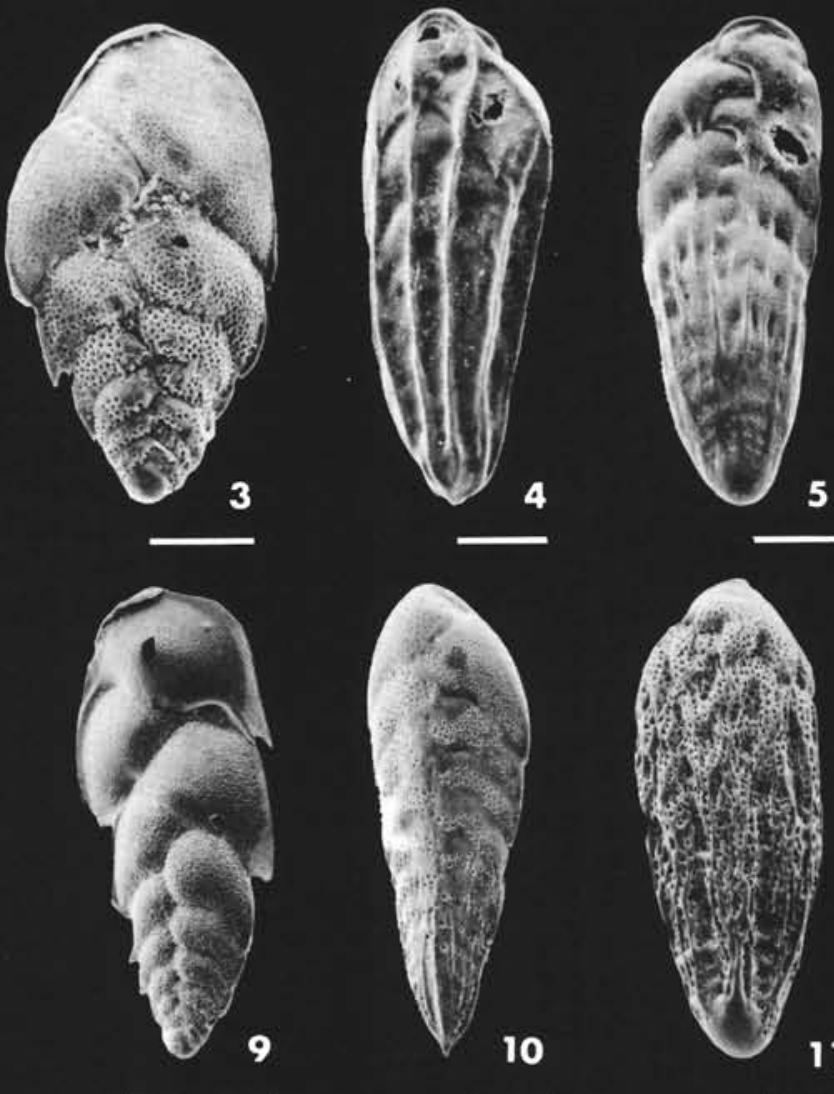

10
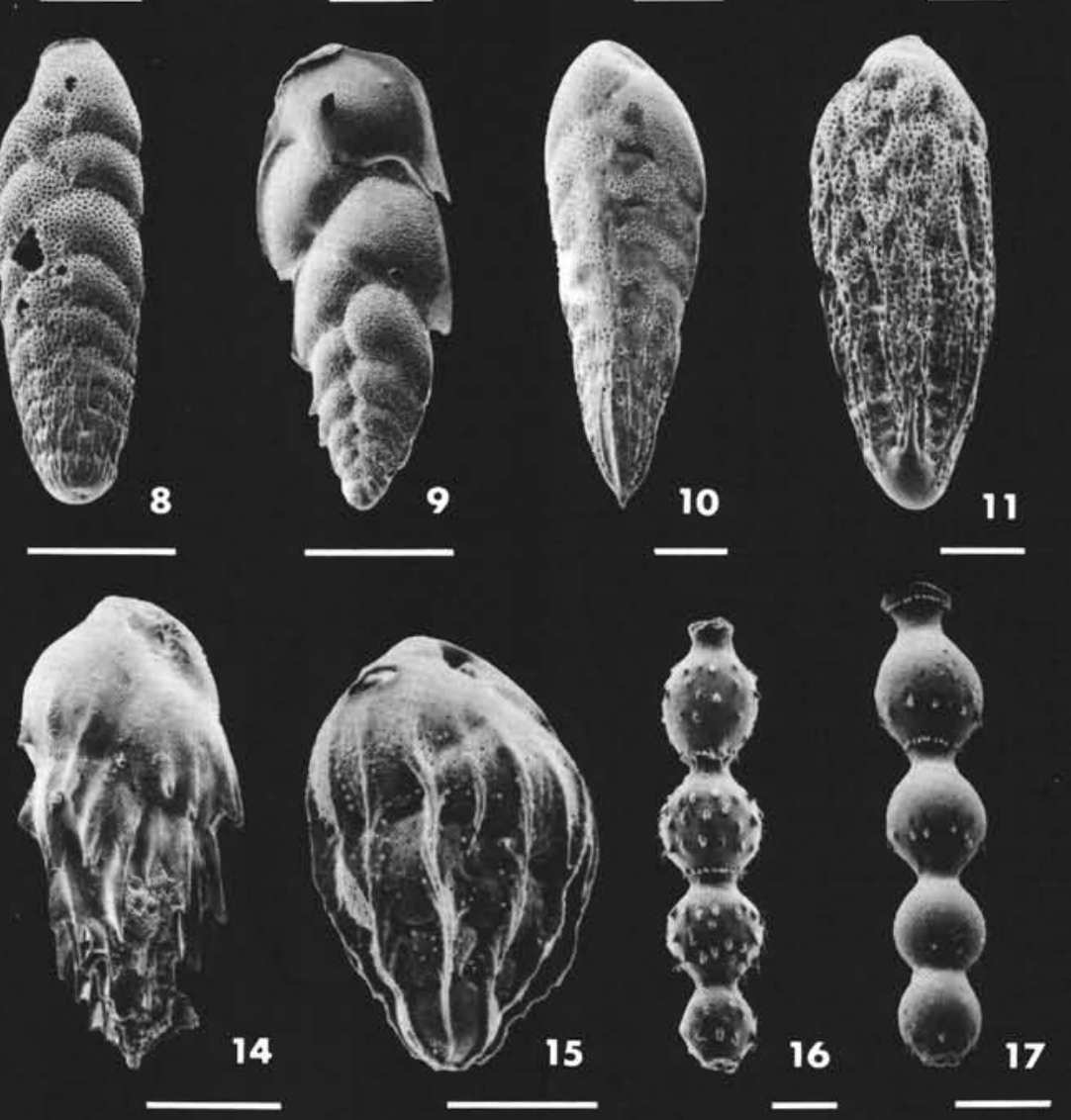

Plate 3. (Scale bars $=100 \mu \mathrm{m}$ unless otherwise indicated.) $1,4,6,8,13$. Sample 570-5,CC, (1) Buliminella subfusiformis Cushman, (4) Bolivina bicostata Cushman, (6) Bolivina bradyi Asano, (8) Bolivina plicata d'Orbigny of Resig, bar $=300 \mu \mathrm{m}$, (13) Bulimina denudata Cushman and Parker. 2, 17. Sample 568-41-3, 123-127 cm, (2) Sphaeroidina bulloides d'Orbigny, (17) Stilostomella gracilis (Palmer and Bermudez). 3, 7, 11-12, 14. Sample 570-4-1, 40-44 cm, (3) Bolivina beyrichi Reuss, Bolivina foraminata Stewart and Stewart, bar $=300 \mu \mathrm{m}$, (11) Bolivina subadvena sulpherensis Cushman, (12) Cassidulinoides bradyi (Norman), (14) Bulimina mexicana Cushman, bar $=300 \mu \mathrm{m}$. 5. Bolivina cf. B. bicostata Cushman, Sample 570-1,CC. 9-10. Bar $=300 \mu \mathrm{m}$. Sample 570-2-3, 20-24 cm, (9) Bolivina pseudobeyrichi Cushman, (10) Bolivina semiperforata Martin. 15. Bulimina alazaensis Cushman, Sample 568-38-1, 80-85 cm. 16. Stilostomella subspinosa (Cushman), Sample 568-38,CC. 


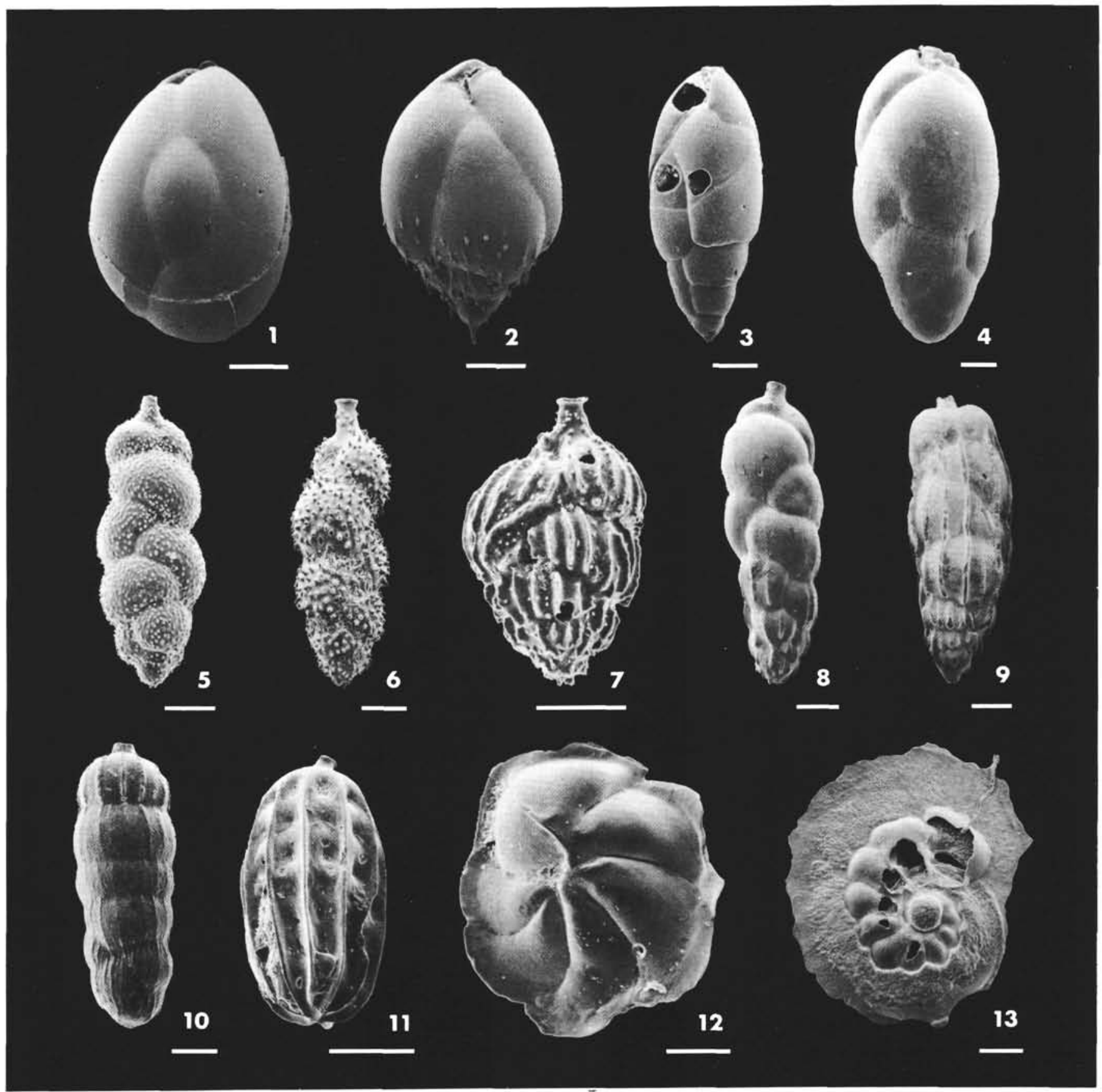

Plate 4. (Scale bars $=100 \mu$ m unless otherwise indicated.) 1-2, 6, 8, 12. Sample 570-4-1, 40-44 cm, (1) Globobulimina pacifica (Cushman), (2) Globobulimina barbata Cushman, (6) Uvigerina rustica Cushman and Edwards, (8) Uvigerina sp., (12) Epistominella smithi (Stewart and Stewart). 3. Praeglobobulimina affinis (d'Orbigny), Sample 568-2-1, 80-84 cm. 4-5, 13. Sample 570-5,CC, (4) Praeglobobulimina affinis (d'Orbigny), (5) Uvigerina hispida Schwager, (13) Laticarinina pauperata (Parker and Jones), bar $=300 \mu \mathrm{m}$. 7. Uvigerina sp., Sample 568-39-3, 82-84 cm. 9. Siphogenerina basispinata Cushman and Jarvis, Sample 568-37-3. 10. Siphogenerina multicostata Cushman and Jarvis, Sample $568-39-3,84-88 \mathrm{~cm}$. 11. Siphogenerina transversa Cushman, bar $=300 \mu \mathrm{m}$, Sample $568-41-3,123-127 \mathrm{~cm}$. 


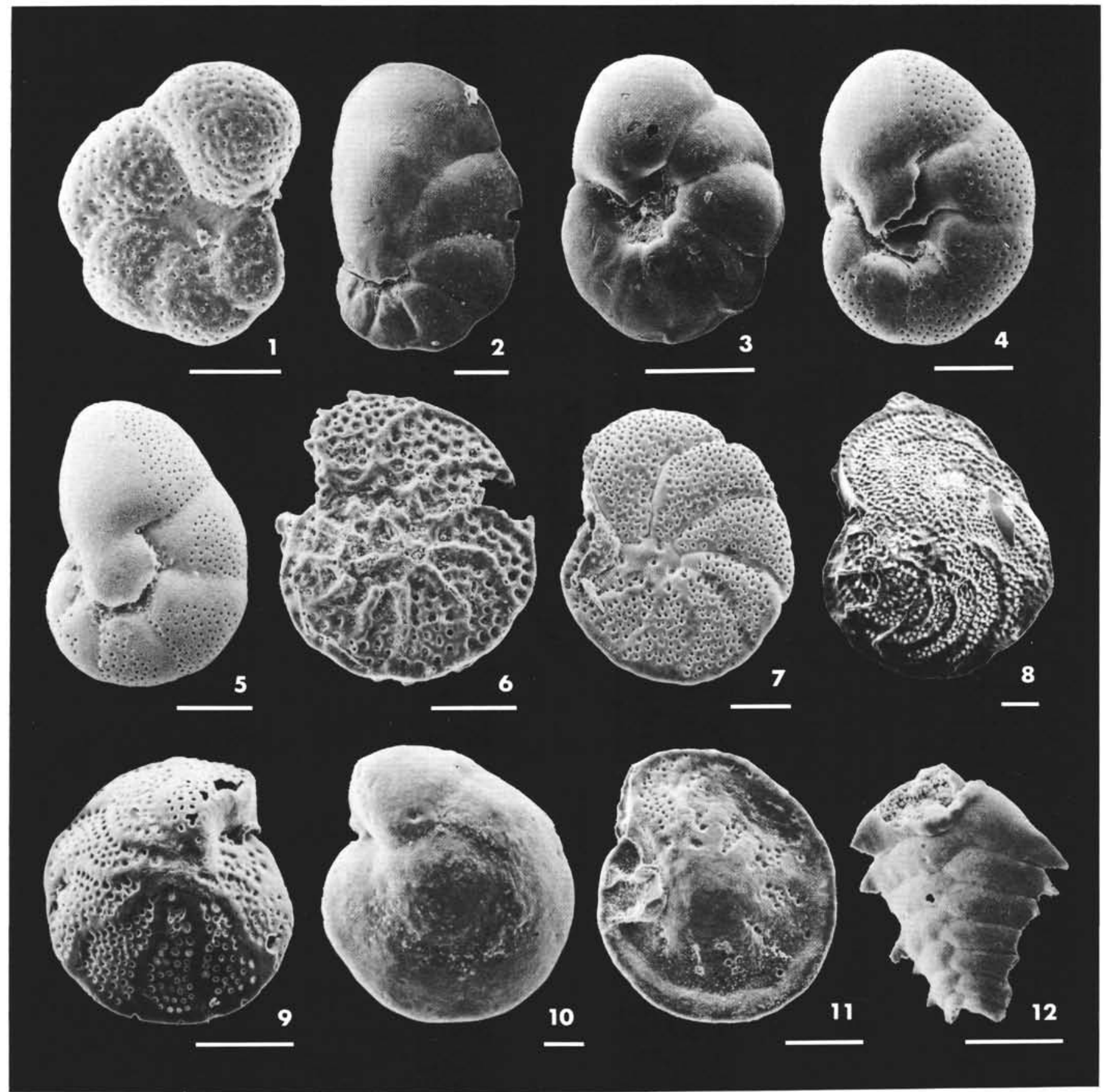

Plate 5. (Scale bars $=100 \mu \mathrm{m}$ unless otherwise indicated.) 1-3. Sample 570-4-1, 40-44 cm, (1) Rosalina columbiensis (Cushman), (2) Cancris sagra (d'Orbigny), (3) Cancris inflatus (d'Orbigny), bar $=300 \mu \mathrm{m}$. 4, 6-7, 12. Sample 570-5, CC, (4) Valvulineria glabra Cushman, (6) Planulina exorna Phleger and Parker, (7) Planulina ornata (d'Orbigny), (12) Suggrundia eckisi Natland. 5. Valvulineria inaequalis (d'Orbigny), Sample 570-2-3, 20-24 cm. 8-9. Sample 568-41-3, 123-127 cm, (8) Planulina renzi Cushman and Stainforth, (9) Cibicides spiralis Natland. 10. Cibicides sp., bar $=30 \mu \mathrm{m}$, Sample 570-1,CC. 11. Cibicides yaqatensis Bermudez, Sample 568-39-3, 84-88 cm. 


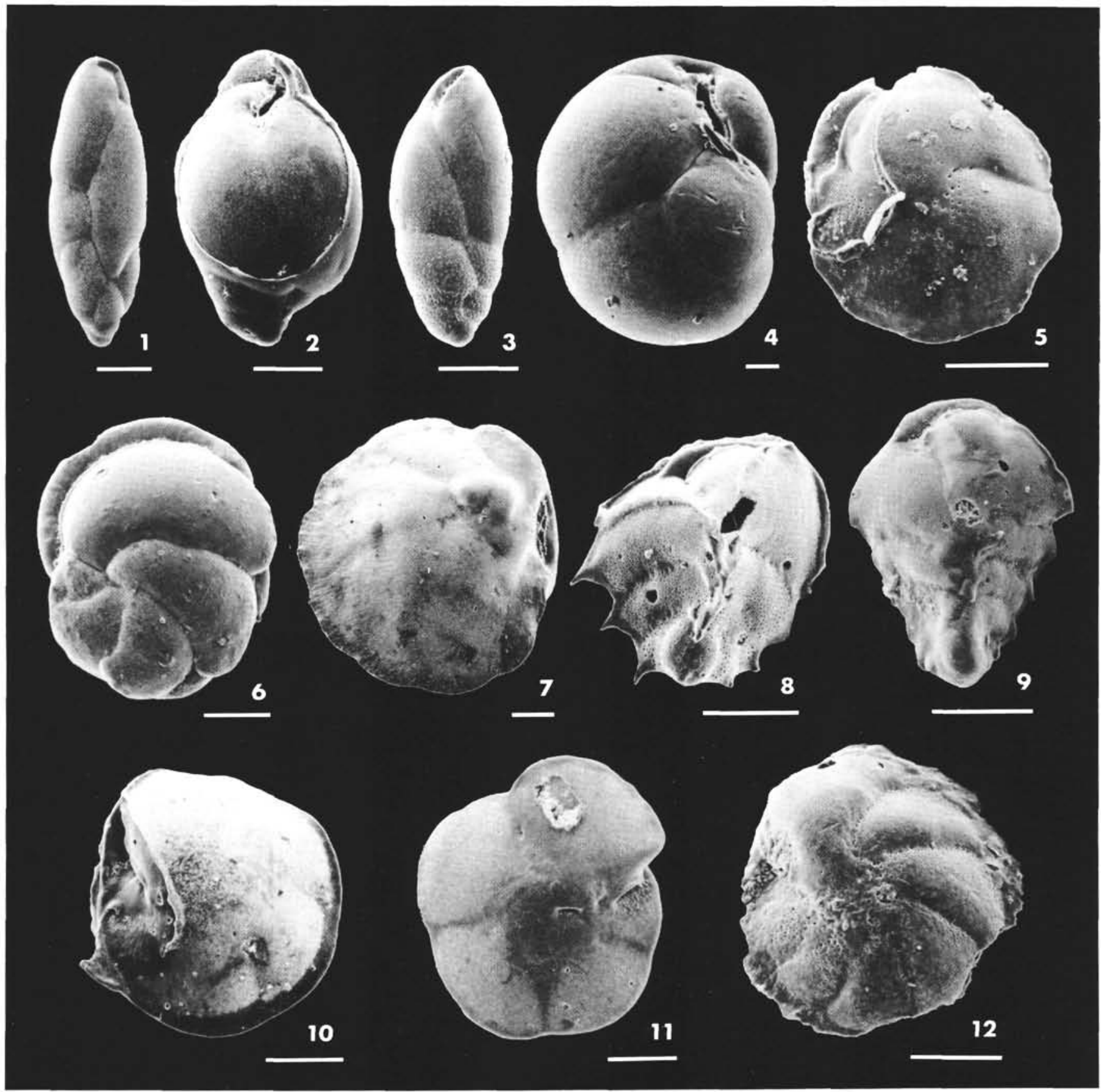

Plate 6. (Scale bars $=100 \mu \mathrm{m}$ unless otherwise indicated.) 1, 11. Sample 568-2-1, 80-84 cm, (1) Fursenkoina bramletti (Galloway and Morrey), (11) Oridorsalis umbonatus (Reuss). 2-3, 5-7, 9. Sample 570-4-1, 40-44 cm, (2) Fursenkoina cornuta (Cushman), (3) Fursenkoina rotundata (Parr), (5) Cassidulina limbata Cushman and Hughes, (6) Cassidulina cf. C. delicata Cushman, (7) Cassidulina laevigata d'Orbigny, (9) Ehrinbergina compressa Cushman. 4, 8, 10, 12. Sample 568-41-3, 123-127 cm, (4) Cassidulina california Cushman and Hughes, bar $=30 \mu \mathrm{m},(8)$ Ehrenbergina bradyii Cushman, (10) Alabamina polita Becker and Dusenbury, (12) Osangularia culteri (Parker and Jones). 